UNIVERSIDADE DE SÃO PAULO

FACULDADE DE EDUCAÇÃO

FRANCISCO VEIGA DE MORAES

O IDEAL DE FORMAÇÃO E O ENSINO DE FILOSOFIA: A SITUAÇÃO ATUAL DO SABER E DA TAREFA DA EMANCIPAÇÃO 
FRANCISCO VEIGA DE MORAES

\title{
O IDEAL DE FORMAÇÃO E O ENSINO DE FILOSOFIA: A SITUAÇÃO ATUAL DO SABER E DA TAREFA DA EMANCIPAÇÃO
}

\author{
Dissertação apresentada à Faculdade de \\ Educação da Universidade de São Paulo para \\ obtenção do título de Mestre em Educação \\ Área de concentração: Filosofia e Educação \\ Orientador: Prof. Dr. Marcos Sidnei Pagotto- \\ Euzebio
}

São Paulo 
AUTORIZO A REPRODUÇÃO E DIVULGAÇÃO TOTAL OU PARCIAL DESTE TRABALHO, POR QUALQUẺR MEIO CONVENCIONAL OU ELETRÔNICO, PARA FINS DE ESTUDO E PESQUISA, DESDE QUE CITADA A FONTE.

Catalogação na Publicação

Serviço de Biblioteca e Documentação

Faculdade de Educação da Universidade de São Paulo

375.5

M827i
Moraes, Francisco Veiga de

O ideal de formação e o ensino de filosofia: a situação atual do saber e da tarefa da emancipação/ Francisco Veiga de Moraes; orientação Marcos Sidnei Pagotto-Euzebio. São Paulo: s.n., 2016.

$121 \mathrm{p}$.

Dissertação (Mestrado - Programa de Pós-Graduação em Educação. Área de Concentração: Filosofia e Educação) - - Faculdade de Educação da Universidade de São Paulo.

1. Filosofia (estudo e Ensino) 2. Filosofia 3. Educação 4. Lyotard, Jean-François I. Euzebio, Marcos Sidnei Pagotto, orient. 
Nome: MORAES, Francisco Veiga de

Título: O ideal de formação e o ensino de filosofia: A situação atual do saber e da tarefa de emancipação.

Dissertação apresentada à Faculdade de

Educação da Universidade de São Paulo para obtenção do título de Mestre em Educação

Aprovado em:

Banca Examinadora

Prof. Dr. Instituição:

Julgamento: Assinatura:

Prof. Dr. Instituição:

Julgamento: Assinatura:

Prof. Dr. Instituição:

Julgamento: Assinatura: 


\section{AGRADECIMENTOS}

Durante o período de realização deste trabalho muitos participaram e me ajudaram no percurso desta jornada. Não somente no transcorrer destes últimos anos, mas ao longo de meu bacharelado e licenciatura em Filosofia, como a partir do momento em que passei a lecionar Filosofia.

Ao meu orientador Marcos Sidney Pagotto-Euzebio, agradeço pela dignidade intelectual, artigo pouco frequente em nossos dias, que permeou o nosso convívio e que permitiu que muitas ideias pudessem tomar a consistência que buscávamos.

Agradeço aos meus pais, Marilda Lyra Veiga e Ivan Vasco de Moraes, que ao meio de tantas reviravoltas pelas quais passamos nos últimos anos, nunca deixaram de trazer apoio, conforto, força e amor para seguirmos adiante, mesmo nos momentos em que a alegria não parecia estar próxima. Agradeço também ao meu irmão que mesmo distante conseguiu manter os laços de companheirismo que nos ajudaram a refletir sobre nossos incertos caminhos.

Aos meus amigos, cujo companheirismo só se fortaleceu desde aquele longínquo primeiro ano de graduação e que tanto me ajudaram na realização desta dissertação: Anderson Silva, Mauro Dela Bandera, Virginia Ferreira, Flavio Reis, Fernando Lopes, Julio Valim, Natalia Leon. Agradeço ao amigo Rafael Pereira que tão amigavelmente colaborou com suas leituras e constantes conversas nos últimos anos. Agradeço também aos companheiros Nicolau Dela Bandeira, Diego Scalada, Diego Amaral, Renan Buchini, Lilian Falcão, Rafael Versolato, Alfredo Christofoletti, Renato Spinosa, Paulo Borges, Martha Costa, Vanessa Amaral, Carol Grego, Geisi Dionisio, Natalia Frizzo, Marcos Camolezi, Mariana Gazeta, Maria Cristina Longo, Bruno Ranieri e Guilherme Corrêa.

Aos queridos amigos de longa data Sandro Detoni, Vanderlei e Vagner Mastropaulo. Agradeço à longa amizade De Mario Sérgio Buchalla e a de sua família, a minha amiga e 'irmã' Juliana Oliveira e também aos amigos santistas Daniel Ferreira e Tatiana Garcia.

Agradeço pelo carinho e acolhimento das amigas Anike Laurita, Isabel Eça, Joana Eça, Maria Izabel Guimarães, Maria Borin, Cecilia de Nichile, Gabriela Campos, Vanessa Santos, Thais Siqueira, Fernanda e Juliana Diniz, e meu amigo Leonardo também. Aos meus amigos professores Artur Gasparini, Érico Pedroso e Gabriel Santos.

Aos meus atuais e ex-alunos que tanto me ensinaram nos últimos seis anos e continuam a me ensinar e que tanto me motivaram a realizar este trabalho. 
“(...) alma tímida, antes de penetrar mais longe em tais extensões inexploradas de terra, dirige teus calcanhares para trás e não para frente. Escuta bem o que te digo: dirige teus calcanhares para trás e não para frente, como os olhos de um filho que se desviam respeitosamente da contemplação augusta do rosto materno; ou melhor, como um ângulo a perder de vista de grous friorentos meditando muito, que durante o inverno, voa poderosamente através do silêncio, todas as velas enfunadas, na direção de um ponto determinado no horizonte, de onde, subitamente, parte um vento estranho e forte, precursor da tempestade."

(Conde de Lautréamont) 


\section{RESUMO}

A proposta desta dissertação incide sobre a discussão das possibilidades e potencialidades do ensino de Filosofia - na etapa do ensino médio - abordado sob a perspectiva de suas conexões com o ideal de formação. Uma vez que a pesquisa seguiu o caminho de relacionar a formação com a metanarrativa emancipadora do Iluminismo, foi importante examinar até onde persiste a força desse ideal, que passa a não ter a mesma resguarda de legitimação de outrora. Esta forma de encaminhar o debate está baseada na discussão sobre a pós-modernidade proposta por Jean-François Lyotard. Partindo destas considerações, a pesquisa buscou examinar textos que abordam a relação do ensino de filosofia com o ideal de formação na situação contemporânea recorrendo a autores como Celso Favaretto, Silvio Gallo, Walter Omar Kohan e Franklin Leopoldo e Silva. Após examinar o que se entende por ideal de formação - assim como a forma que ela pode ser associada a uma metanarrativa emancipadora - e também suas conexões com o ensino de filosofia, a pesquisa discute aspectos chaves da filosofia de Lyotard para pensar a educação e também voltar a refletir sobre quais maneiras o ensino de filosofia pode tomar forma no cenário atual.

Palavras-chave: Educação, Filosofia, Ensino de Filosofia, Formação, Jean-François-Lyotard 


\begin{abstract}
The purpose of this dissertation is to focus on the discussion of the possibilities and potentialities of the teaching of Philosophy - in high school level - approached from the perspective of its connections to the formation ideal. Once the search has taken the path of relating formation with the emancipatory metanarrative of the Enlightenment, it was important to examine how far the strength of this ideal remains, which does not have much of the same legitimacy protection as before. This way of routing the debate concerns the discussion of postmodernity proposed by Jean-François Lyotard. Based on these considerations, the research sought to examine texts that approach the teaching of philosophy related to the formation ideal in the contemporary situation counting on authors such as Celso Favaretto, Silvio Gallo, Walter Omar Kohan and Franklin Leopoldo e Silva. After examining what is meant by formation ideal - as well as how it can be associated with an emancipatory metanarrative - and its connections with the teaching of philosophy, the research discusses key aspects of Lyotard's philosophy to reflect on education and also to re-think about what ways the teaching of philosophy may take shape in the current scenario.
\end{abstract}

Keywords: Education, Philosophy, Teaching of Philosophy, Formation, Jean-FrançoisLyotard 


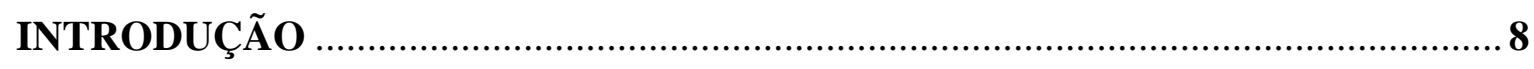

1. PARA UMA IDEIA OU NOÇÃo DO SENTIDO DE FORMAÇÃO A PARTIR DA

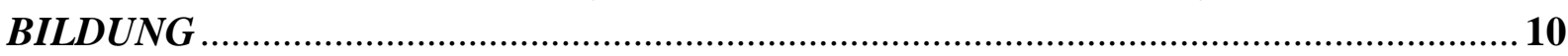

2. O IDEAL DE FORMAÇÃO E O DECLÍNIO DAS METANARRATIVAS NA

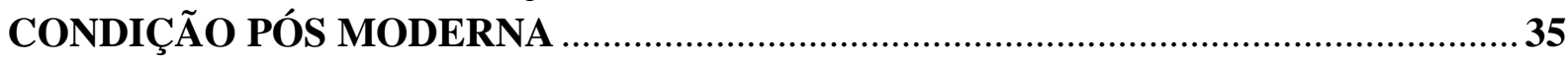

3. SOBRE AS CONEXÕES ENTRE ENSINO DE FILOSOFIA E IDEAL DE

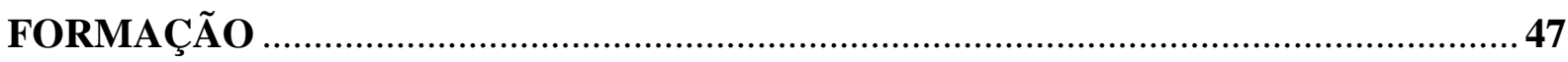

4. O ACONTECIMENTO, O DIFERENDO E A ESCRITURA, TÓPICOS

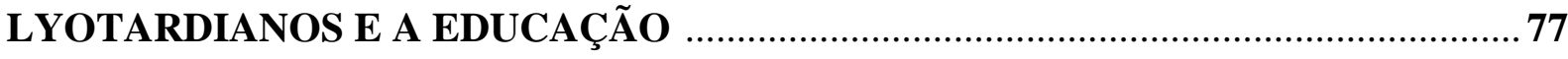

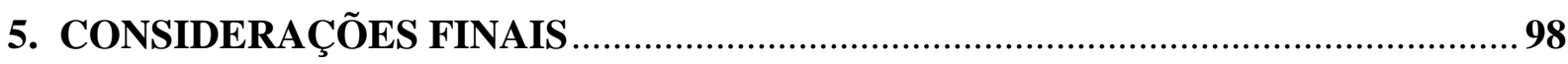

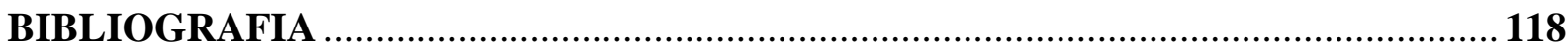




\section{Introdução}

Em carta escrita ao amigo Hugo Vermeren em 20 de outubro de 1984, Jean-François Lyotard responde a um pedido para se dedicar a reflexão sobre a formação filosófica dos professores por ocasião de uma série de encontros acadêmicos com o tema "Escola e Filosofia".

Nesta carta, que veio a ser incluída na coletânea de cartas "o pós-moderno explicado às crianças" sob o título "Mensagem a propósito do curso fillosófico", o autor lança uma discussão que extrapola o objetivo inicialmente apresentado, ao ponto de quase o rejeitar. Entre os pontos discutidos, Lyotard aponta no final da carta um "diferendo", termo que dá nome ao livro publicado no ano anterior, entre o idioma falado pelo curso filosófico e o idioma falado pelos alunos. De um lado um idioma que suspende a pressa e a velocidade que o mundo exige, de outro um idioma que é falado pelos alunos, mas que é o idioma corrente do mundo que veicula valores como sucesso, performance, gozo além de seu ritmo acelerado em nome do ganho de tempo. Idiomas que ele considera incomensuráveis um ao outro e que não podem ser resolvidos por tribunal algum, estando professor e alunos igualmente no papel de vítimas.

Este ponto específico da carta de Lyotard acabou por ser, se não o ponto de partida para a questão discutida nesta dissertação, ao menos seu guia condutor - e também motivador. O objeto que esta dissertação visou investigar foi o ensino de Filosofia, tornado obrigatório nas escolas brasileiras em cada um dos anos do Ensino Médio ${ }^{1}$.

Entre os muitos caminhos que a discussão sobre este objeto pode tomar, foi feita a opção de explorar as possíveis relações entre o que costumamos chamar de ideal de formação com o ensino de Filosofia.

Uma vez que o ideal de formação foi o tema chave que me permitiu abordar e interpretar uma série de escritos sobre o ensino de Filosofia, foi de suma importância iniciar a dissertação com um capítulo que discutisse o tema - que está longe de ser inequívoco - assim como suas vinculações com a modernidade e com o humanismo, sobretudo quando aproximamos o termo formação do termo alemão Bildung.

\footnotetext{
${ }^{1}$ A obrigatoriedade é decorrente da promulgação da lei número 11.684 de dois de junho de 2008 que altera o artigo 36 da Lei $\mathrm{n}^{\circ}$ 9.394, de 20 de dezembro de 1996, estabelecendo as Diretrizes e Bases da Educação Nacional, para incluir a Filosofia e a Sociologia como disciplinas obrigatórias nos currículos do ensino médio. A alteração maior está no inciso IV do primeiro artigo: "serão incluídas a Filosofia e a Sociologia como disciplinas obrigatórias em todas as séries do ensino médio".
} 
No segundo capítulo, procurei discorrer sobre o melhor modo de situar os intentos formativos na contemporaneidade. Para tanto, fiz recurso novamente ao filósofo Lyotard, desta vez na obra "A Condição pós-moderna". Seu tema central é o declínio ou descrença das metanarrativas com seu poder de legitimação, orientação e unificação de saberes, práticas ou experiências. Ali se delimitou melhor a discussão sobre a seguinte questão: Se os ideais modernos não possuem o mesmo poder de legitimação de outrora, o mesmo pode ser dito sobre o ideal de formação?

Colocada esta questão, ela pode apontar para três diferentes formas de abordar a relação entre ensino de Filosofia e ideal de formação. Em cada uma das formas encontramos uma discussão sobre a maneira que este ideal nos influência e seus respectivos posicionamentos diante da questão. Neste terceiro capítulo discutimos textos e artigos dos seguintes autores: Celso Favaretto, Ricardo Fabbrini, Silvio Gallo, Walter Omar Kohan e Franklin Leopoldo e Silva.

Para o capítulo final, selecionei alguns tópicos da filosofia de Lyotard que podem ser relacionados à ação educacional e também ao ensino de Filosofia. Entre os tópicos, cito alguns: a noção de diferendo, a escuta e a escritura, o recurso à anamnese, entre outros. Estes temas que além de se mostrarem oportunos para discutir a educação contemporânea - mas de alcance diminuto se comparado com autores contemporâneos a Lyotard, sobretudo Gilles Deleuze e Michel Foucault - todos eles guardam alguma conexão ou afinidade com a questão primeira que inspirou e provocou esta dissertação, citada no início desta introdução: o diferendo entre professor e aluno. 


\section{Para uma ideia/noção do sentido de formação a partir da Bildung.}

Neste capítulo introdutório, a intenção será a de apresentar o ideal de formação enquanto fim educacional, sua relação com a noção ou conceito de 'Bildung' e o modo como estes contém e apresentam propósitos humanistas e iluministas ${ }^{2}$ que tomarão forma nos intentos educacionais, portanto formativos. Assim, o ideal de formação que tentamos circunscrever, para aproximá-los do que pode ser proposto para o ensino de Filosofia na etapa média da trajetória escolar, estaria situado, de modo mais preciso, no momento histórico da modernidade em que ideais de autonomia e emancipação do homem são colocados de maneira mais direta, no sentido de se opor a uma concepção de homem e sua relação com o mundo/realidade que se mostrava dominante naquilo que costumou ser chamado de antigo regime. Assim nos afastamos de um entendimento de formação que a ideia de paideia pode evocar, no sentido de formação do homem grego, mesmo que as afinidades existentes não possam ser ignoradas. Enquanto a ideia de paideia leva a uma noção de formação que é a de continuidade da transmissão ou propagação de uma cultura entre as gerações, a noção de formação na acepção moderna, ainda que esteja carregada também desta intenção, se afirma inicialmente como uma proposta transgressora a uma ordem que era entendida como impeditiva da plena autonomia humana. Desta maneira, entendo que a Bildung moderna contenha em si tanto a ideia de conservação quanto a de transgressão ou simplesmente de singularização. Tentarei então investigar se há uma combinação de potências antagônicas; de que maneira estão presentes nos discursos que melhor nos indicam os traços da Bildung que se impuseram historicamente às pretensões educativas; e como elas tomam forma quando a Filosofia se coloca no espaço escolar ${ }^{3}$.

Sugiro desde já algo que deve ser examinado. Será que o potencial transgressor moderno de tudo transformar para recomeçar tenha obnubilado a outra potência? Podemos perceber que o ideal de formação está vinculado às pretensões que podemos chamar de 'heroicas', uma vez que se voltam contra uma ordem que pretendem superar a partir de outra, que propõe colocar a humanidade no caminho de sua emancipação.

A imagem maior de uma ideia de formação que passa pela emancipação pode ser

\footnotetext{
${ }^{2}$ Creio que o interesse em entender o que ainda existe destes propósitos no ideário moderno pedagógico e nos planos vigentes para educação não pode ser menosprezado. Para Favaretto $(2012$, p.7, 8) a "referência ao pensamento iluminista ainda é determinante em grande parte do que somos, pensamos e fazemos hoje, ainda que seja insuficiente para dar conta da indeterminação e do insuportável da experiência contemporânea".

${ }^{3}$ A discussão mais específica sobre a formação e o ensino de filosofia se dará no próximo capítulo.
} 
encontrada na definição de esclarecimento feita por Kant em seu célebre escrito "Resposta à pergunta: o que é o esclarecimento?". O termo Aufklärung, aqui traduzido por esclarecimento, pode ser colocado ao lado não apenas do termo Bildung, mas também de outros tais como eruditio ou Paideia (SUAREZ, 2005, p. 192). Também podemos lembrar de termos como phrónesis, Weisheit, entre outros que constituiriam uma família de termos com diversos traços comuns e distinções não tão marcadas ou definidas (CORDEIRO, 2008, p.138). Na definição que propõe o imperativo de sair do estado de tutela alheia do qual o indivíduo é o próprio culpado por nele permanecer, ou seja, aquilo que Kant chama de estado de menoridade, encontramos leituras e encaminhamentos vários. Foucault já destacaria aí o momento ímpar da história da Filosofia em que se coloca uma reflexão sobre a atualidade, no sentido de tentar descobrir "qual a diferença que ele introduz hoje em relação a ontem? (2005, p. 337)". Também não é de se espantar que a presença deste texto nos materiais didáticos do ensino de Filosofia tenha uma proporção dificilmente alcançada por outros textos ou temas, devido principalmente à força e relevância de suas teses que parecem não se restringir ao movimento iluminista. Como Foucault indica no artigo "O que são as luzes", Kant não interroga o momento presente preocupado com a compreensão de sua totalidade ou de como ele antecede ou prepara uma realização futura, mas nas peculiaridades que apresenta em relação a outros períodos. É no modo em que formula sua questão apontando a sua pura atualidade que podem estar indícios da relevância e força destas teses.

O texto, além de ser exemplar na maneira em que expressa o espírito do Iluminismo, traz também o modo peculiar pelo qual a Filosofia formula, a partir de suas bases, a exigência política pela busca de um movimento de libertação frente uma certa sorte de jugo. Desde então o lema Sapere aude, sintetiza o Iluminismo em seu pendor de fazer do homem senhor de $\mathrm{si}^{4}$.

O interesse desse texto para fins pedagógicos ou educativos não é reduzido se comparado aos fins da Filosofia ou da política ${ }^{5}$. O aprendizado exige assim o reconhecimento de um jugo - ao qual o homem é responsável por nele permanecer - que depende somente da coragem e ousadia daquele que permanece nesta condição. Não se pode colocar a responsabilidade da permanência neste estado em nenhuma outra instância. O caráter

\footnotetext{
${ }^{4}$ Podemos discutir também se outros momentos desse mesmo texto minimizam um entusiasmo quase revolucionário e se se coloca em um tom mais conformista ao propor a distinção entre dois usos da razão: um público e outro privado. Em outro momento, tratarei disso ao lado do texto "Ideia de uma história universal de um ponto de vista cosmopolita", o que pode nos situar melhor diante dos intentos formativos legados pelo Iluminismo.

${ }^{5}$ Como veremos adiante, para Schiller, o interesse pedagógico será o mesmo do político.
} 
individual da iniciativa do esclarecer, que parece tomar forma também no progredir do conhecimento, vai adquirindo contornos mais individualizantes no desenvolver deste texto e talvez também em outros.

Esclarecimento como autoformação e busca de autonomia do indivíduo, a partir aqui do recurso a Kant, apresenta esses dois traços maiores da Bildung, que insistem em permanecer em nosso presente cenário educacional. Ainda assim, vamos a busca de outros aspectos que a Bildung possa apresentar.

Para além do recurso a textos clássicos da Filosofia, situados ou não no período do Iluminismo, que contenham propostas de formação que nos ajudem a pensar a Bildung ou que a esta possam ser relacionados, nos será útil um sobrevoo à ideia de Bildungsroman, habitualmente traduzido por romance de formação. Com isto, creio que podemos encontrar novos traços que podem ainda estar presentes nos desígnios educativos que foram ou ainda são propostos, ou redimensionar aqueles que encontramos nos discursos filosóficos.

Nesta aproximação da Bildungsroman, passamos a discutir a ideia de formação sob dois aspectos: o trabalho e a jornada ou viagem (SUAREZ, 2005, p. 193). A ideia de formação no ideário cultural alemão passa acentuadamente por tais dimensões. A forma mais acabada da presença da Bildung nestas relações é a da obra clássica de Goethe: "Os anos de aprendizagem de Wilhelm Meister".

Ainda antes de examinar tal dimensão, tentemos situar melhor como Rosana Suarez pretende conceituar o termo Bildung a partir de outro autor ${ }^{6}$ :

A palavra alemã Bildung significa, genericamente, "cultura" e pode ser considerado
o duplo germânico da palavra Kultur, de origem latina. Porém, Bildung remete a
vários outros registros, em virtude, antes de tudo, de seu riquíssimo campo
semântico: Bild, imagem, EinBildungskraft, imaginação, AusBildung,
desenvolvimento, Bildsamkeit, flexibilidade ou plasticidade, Vorbild, modelo,
Nachbild, cópia, e Urbild, arquétipo. Utilizamos Bildung para falar no grau de
"formação" de um indivíduo, um povo, uma língua, uma arte: e é a partir do
horizonte da arte que se determina, no mais das vezes, Bildung. Sobretudo, a palavra
alemã tem uma forte conotação pedagógica e designa a formação como processo.
Por exemplo, os anos de juventude de Wilhelm Meister, no romance de Goethe, são
seus Lehrjahre, seus anos de aprendizado, onde ele aprende somente uma coisa, sem
dúvida decisiva: aprende a formar-se (sich bilden).

${ }^{6} \mathrm{O}$ artigo de Suarez, aqui citado, estuda o conceito de Bildung a partir do artigo de Antoine Berman: Bildung et Bildungsroman. Le temps de la réflexion, v. 4, Paris, 1984. 
Assim, o termo apresenta uma possibilidade de usos e acepções ampla, sendo pertinente aqui a tarefa de encontrarmos o que foi colocado no campo educacional de maneira mais tangível, para daí sabermos melhor de que maneira nos localizar diante dos desafios ou exigências colocadas à Filosofia que vai às escolas.

O tempo da formação sugerido na imagem da jornada do herói de Goethe - que concomitante ao seu processo de aprendizagem - se mostra como um percurso em que a personagem ou sujeito da formação se aventura para além de seu ponto de origem. O estranhar do encontro com a alteridade, distinta do acolhimento do lar paternal ou da pátria, projeta para aquele que se forma um reencontro consigo ou com aquelas disposições potenciais das quais só poderiam se manifestar nesta jornada. Assim, o contato com o outro é também um encontro consigo próprio. De maneira que o autoconhecimento depende de uma relação com algo de exterior e não de interior (QUINTALE NETO, 2005, p. 197).

É importante frisar que pouco importa o lugar da viagem, o seu destino ou roteiro da viagem, mas o que ocorre ao longo do percurso que permite o desenlace final. A viagem que permite a personagem dos Bildungsroman o contato com a alteridade pode também sugerir um formar-se para a vida social. Ideia que parece também estar contida na imagem da Bildung como trabalho.

Sendo que a jornada de Wilhelm Meister se inicia pela necessidade de negócios familiares, será a própria atividade de trabalho que impulsiona Wilhelm Meister na sua jornada paradigmática de formação. Assim, tal imagem mostra como a Bildung não pode dispensar seu caráter ativo. O círculo familiar é abandonado apenas pelo impulso da realização da tarefa que o coloca na ação, ressaltando sua dimensão prática. Suarez (2005, p.194) ressalta o que seria um movimento dialético que este chamado à atividade apresenta. $O$ trabalho é por um lado limitador uma vez que restringe o indivíduo naquelas tarefas das quais se ocupa, mas por outro essa autorresponsabilização tem caráter também universalizante a partir do momento em que a ocupação assumida e bem realizada o dota de novas possibilidades que deixam de limitá-lo.

Ação e exterioridade se combinam na obra de Goethe, como sugere Quintale Neto (2005, p. 197) a partir de Gyorg Lukács. A personalidade do homem deve se desenvolver 
somente em sua ação, uma vez que ocorrerá na interação social com outros. Assim a formação exige que o indivíduo se torne um homem da práxis $^{7}$, de ação no mundo e na natureza.

Esta inserção na práxis, que o processo de formação empreende, acaba por oferecer, na estrutura do Bildugsroman, o contato com valores humanistas (QUINTALE NETO, 2005, p. 194). Não somente tal contato advém ao personagem no desenvolvimento do romance, mas também se espera que o leitor ao acompanhar tais desventuras seja formado em valores tais como tolerância religiosa, ideal de igualdade e fé no homem e na natureza. Desta maneira o personagem goethiano irá se instruir em tais valores do mesmo modo que o autor espera que ocorra com seus leitores como representantes dos homens desta época de esclarecimento. Deste modo, podemos entender que Goethe também concebe que é papel da arte formar os homens deste novo tempo ${ }^{8}$.

Ora, ao notarmos que a tradução de Bildung oferece possibilidades como cultivo e cultura, podemos passar a discutir o papel da $\operatorname{arte}^{9}$, não apenas no romance de Goethe em particular, mas também no Bildungsroman. Meister não se ocupa somente das atividades que sua profissão exige, mas também se integra a um grupo de personagens, atores inclusos, que se engajam na representação teatral.

A viagem de formação é também encontro com as expressões culturais que as outras gerações ou povos distantes nos legaram. A formação exige assim o contato com a alteridade em seus eixos temporal e espacial. Walter Benjamin já ressaltara estes elementos como formadores das primeiras famílias de narradores, em seu célebre ensaio sobre Nikolai Leskow. Ali os arquétipos ou tipos fundamentais do camponês sedentário e do marinheiro comerciante parecem operar na via que aponta Suarez. O percurso da formação passa pelo encontro daquilo que homens em outros tempos e outras terras constituíram em suas culturas. O confronto com elas não somente é inevitável, mas também desejável nesta jornada que forma o contador de histórias, o artista ou o homem que age na vida social.

\footnotetext{
7 O termo práxis é usado por Quintale Neto em oposição à contemplação. A formação pressuposta em fundamentos humanistas passaria por uma síntese entre contemplação e práxis $(2005$, p. 186). O termo também indica, para o autor, ação na natureza e no mundo que levariam à formação e ao conhecimento de si e da humanidade (p.197).

${ }^{8}$ Questão fundamental para Schiller, que será alvo de discussão ainda neste capítulo.

${ }^{9}$ Suarez oferece outras duas imagens para a Bildung que seriam tradução e a viagem à antiguidade ou a filologia. Apontarei aqui o papel da cultura e da arte nestas imagens.
} 
Indícios destes apontamentos podem ser encontrados ao notarmos Meister trazendo para seu grupo o teatro inglês de William Shakespeare ou nas traduções das tragédias gregas pelos românticos alemães. Assim, não é a toa que Suarez destaca o sentido que Bildung assume de provação do estrangeiro, do estranho (2005, p. 195) nesta autoformação.

Mas no caso do termo alemão, o outro temporal e espacial com o qual é preciso se medir costuma ser o do homem grego ${ }^{10}$. A antiguidade e suas obras ocupam um lugar com o qual a ideia de Bildung se ocupa.

Schiller na célebre obra "A educação estética do homem" também traz a busca por este ideal referenciado no grego. Se no mundo moderno só se vê fragmentação das esferas, a unidade entre arte, filosofia e religião colocava o homem grego ou o ateniense como digno representante de seu tempo. Poucas imagens mostram melhor a admiração destes humanistas e iluministas da era moderna do que a do ateniense que daria sua vida em luta pelo destino da humanidade. $\mathrm{O}$ homem moderno que se deixou levar exageradamente pelo seu entendimento fez com que este cindisse tais esferas, enquanto o grego continua a ser fiel representante do seu tempo por ter suas forças provenientes da natureza que seria por princípio unificadora. Aqui, a figura da natureza é mais do que inspiração, como indicado antes nos princípios humanistas $^{11}$ do romance de Goethe, mas também ideal de unificação da experiência, princípio tão caro às aspirações da formação tanto em Schiller como nas propostas educacionais contemporâneas.

A presença dos gregos como modelo e arquétipo se fez pelo motivo de serem entendidos como originais e eternos. Winckelmann (SUAREZ, 2005, p. 196, 197) recomenda aos alemães a paradoxal receita para a originalidade em sua cultura: é preciso imitar os antigos, eis a chave para ser inimitável.

Ideia que talvez seja um pouco incômoda para os rumos atuais do debate educacional quando propõe que o ideal de formação deve partir de um arquétipo ou modelo. O processo de formação se dá de maneira independente e livre ou faz uso da instrução de uma outra figura ou algum tipo de mestre? Mas nesta imagem de formação que entendemos ainda como autoformação, encontramos a necessidade do encontro com a alteridade. Este encontro não

\footnotetext{
10 J.F. Weber $(2006,126)$ afirma que entre os modos de tratamento da Bildung, dois passam pelo ideal do homem grego: os clássicos e neohumanistas recorrem à arte e filosofia da Grécia antiga, enquanto Nietzsche e Holderlin vão até o período da Grécia arcaica para buscar seu modelo.

${ }^{11}$ Para Quintale Neto (2005, p. 194), os princípios humanistas que guiam o Bildungsroman goethiano resumemse a: tolerância religiosa, ideal de igualdade, fé no homem e na natureza e o culto à humanidade.
} 
pressupõe, de modo necessário, que ocorra uma relação entre mestre e aprendiz. De que maneira ainda permaneceria tal traço da Bildung no discurso contemporâneo? Que transformações ela sofreu e de que maneira, ainda será investigado. Por enquanto não isolemos este aspecto daquele da viagem e do confronto com o estranho que pode ocorrer com maiores ou menores atritos.

Se ao traduzirmos o termo Bildung para formação temos a dimensão pedagógica ressaltada, isto pode indicar dois caminhos, como aponta José Fernandes Weber (2006, p. 127): o primeiro de um empreendimento formativo voltado ao desenvolvimento científico assentado em um solo institucional e um segundo, típico dos romances de formação, em que haveria uma recusa da instituição formativa ressaltando o valor da experiência, também formativa.

Ora tal indicação talvez nos auxilie nos impasses que as tarefas de exigências formativas postas à escola trazem. A escola assim como a universidade são as instituições criadas e legadas pela modernidade para a incumbência da formação. Ainda que nosso interesse maior seja a escola e a filosofia que toma parte nela, a discussão sobre a Bildung nos leva à universidade criada pela iniciativa de Wilhelm Von Humboldt ${ }^{12}$.

A exigência de um solo institucional para a formação se torna preocupação do mais alto nível para a nação alemã que ainda estava para se formar. Assim, a educação formal é chamada para resolver um impasse de seu tempo, no caso o atraso alemão, em termos tanto militar quanto de desenvolvimento, em relação a países como Inglaterra e França (WEBER, 2006, p.121-123).

Humboldt projeta para a universidade, para além de sua missão científica, a produção daquilo que será matéria para a formação moral e intelectual (WEBER, 2006, p.124) tudo feito com a maior autonomia e liberdade frente às intervenções do Estado. Assim as preocupações de desenvolvimento da ciência, não seriam por si, mas em nome de um

\footnotetext{
${ }^{12}$ Wilhelm Von Humboldt se ocupa no final do século XVIII da reforma das instituições escolares, assim como da criação da Universidade de Berlim. Como aponta José Fernandes Weber (2006, p.124) a proposta de organização das Instituições Científicas Superiores contidas no texto Sobre a organização interna e externa das Instituições Científicas Superiores em Berlim são formuladas em resposta às demandas expressas por Johann Gottlieb Fichte em seus Discursos à Nação Alemã que depositavam esperança no desenvolvimento educacional como chave para a resolução dos problemas alemães daquele tempo.
} 
engrandecimento da nação que seria alcançado não somente pelo progresso científico, mas também intelectual e moral.

No discurso de Humboldt convive tanto a ideia de autonomia que deve negar à universidade qualquer finalidade determinada quanto a exigência de formação moral e espiritual. Desinteresse e interesse contidos nas formulações da mesma instituição (LYOTARD, 2011, p.59 e ss). O sujeito a ser formado pode ser entendido como resultado de uma síntese entre as verdadeiras causas da ciência coincidindo com o alcance dos justos fins da vida moral e política. Daí o ideal a ser perseguido pela Bildung proposto pela universidade.

Assim, do que foi discutido até o momento sobre a noção de Bildung, podemos destacar entre os principais traços que podem vir a caracterizar uma imagem ou quadro do que seria entendido por formação - no sentido de Bildung - aspectos como: a busca pela autonomia, o encontro com a alteridade, o distanciamento do lar ou pátria necessário para o encontro consigo, a atualização de potências que não poderiam ser reconhecidas antes, a inserção ou imersão na esfera da práxis, inspiração em um modelo ou arquétipo e, por fim a necessidade de um empreendimento institucional que assegurasse tal desenvolvimento formativo.

Estes aspectos não são territórios estanques ou incomunicáveis. Alguns deles são provavelmente indissociáveis, mas devem ser citados separadamente por indicar algo distinto em relação aos demais.

Feito este esforço para montar um quadro que possa nos orientar ou ao menos dar parâmetros mínimos se quisermos examinar - de modo razoavelmente acurado - a relação entre a Bildung e a Filosofia na escola, passo a examinar textos que julgo oportunos para melhor traçar de que maneira a ideia de formação toma corpo no discurso filosófico.

Ainda que a noção de Bildung assente raízes no solo das intenções iluministas, não reduzirei este intento a filósofos ou a textos nitidamente associados ao período do Iluminismo. Para isto tentarei percorrer um trajeto que se inicia na "Ideia de uma história universal de um ponto de vista cosmopolita" de Immanuel Kant a ser seguido por uma parada em "A educação estética do homem" de Friedrich Schiller a se findar em algumas considerações sobre o "Nascimento da tragédia" de Friedrich Nietzsche.

Em cada uma destas três obras que optei por reunir, encontramos discussões e assuntos diversos, nas quais - cada um a sua maneira - coloca em jogo desígnios formativos ao 
homem, mesmo que isto seja mais claro e direto, sobretudo em Schiller e um pouco menos em Kant, mas também em Nietzsche cuja discussão estaria mais distante por se centrar principalmente em um debate estético, mas que não se exime de averiguar a situação cultural do homem alemão de seu tempo e o que poderia se esperar dele.

Também tentarei explorar o que anunciei anteriormente, que parece não ser meramente acidental, sobre o apontamento de que quando intentos formativos se colocam em ação, encontramos uma duplicidade ${ }^{13}$ de aspectos, impulsos ou até naturezas que formam um par que se apresenta de maneira antagônica em alguma medida. Tal característica é comum a cada um dos textos, de modo que essa duplicidade parece vir a tona no momento em que cada um dos autores examina a potencialidade dos homens de seu tempo e conjectura sobre a forma que tais potências podem assumir

Nas primeiras páginas deste escrito fiz alusão de que a discussão sobre o conceito de esclarecimento em Kant, seria útil no sentido de configurar a proposta formativa de Kant não somente para o indivíduo, mas também para a espécie humana. Se em "Resposta à pergunta: o que é o esclarecimento" encontramos a célebre proposição da saída da menoridade que se realiza pela ousadia e coragem de se livrar de tal estado e colocar seu próprio entendimento como guia último, é no texto "Ideia de uma história universal com um propósito cosmopolita" em que encontramos a dinâmica em que são discutidos as potencialidades humanas, dotadas pela natureza, que devem ser atualizadas na espécie e não somente no indivíduo.

A saída do estado de menoridade não é um caminho fácil, ou espontâneo, a ser trilhado, a coragem deve vencer todo tipo de instrumento artificial que foi legado ao homem, ou por ele criado, para que ele se compraza em sua segunda natureza. Aferrar-se a tal tipo de instrumento estaria em contraste ao que seria natural, sendo somente um mau uso dos dons naturais propiciados por tais entraves (KANT, 2004, p. 12).

Deste modo, o clássico texto que tão bem ilustra os desígnios emancipatórios que o Iluminismo lega à humanidade, vislumbra de modo bastante breve a oposição entre a acomodação do homem ao estado de menoridade e aquilo que seria natural ao homem. $\mathrm{O}$ uso

${ }^{13}$ Stirnimann (apud WEBER, 2006, p.127) concebe a Bildung como “(...) um ideal pedagógico, voltado à resolução do antagonismo entre a vida e o espírito, o genérico e o individual, a natureza e a cultura". Assim nesta concepção de Bildung encontramos também um esforço por resolução de antagonismos 
de "instrumentos mecânicos" então afastaria o homem do que seria seu destino natural. Discussão que será melhor desenvolvida em "Ideia de uma história universal...".

Se o homem carrega em si disposições que a ele foram conferidas pela natureza, elas lá estão por um motivo que será objeto de investigação do filósofo. O plano da natureza, que parece ser colocado aqui de forma inequívoca, há de ser decifrada ao examinarmos a história dos homens.

Daí a importante tese da segunda proposição, em que se jogam o destino e possibilidades do indivíduo e da espécie humana. As disposições naturais serão de fato desenvolvidas na espécie, de maneira que estas não ocorram de modo instintivo, mas mediante tentativas e esforços. Os progressos intentados pela natureza para o homem não hão de se esgotar nos homens tomados como indivíduos, mas se prolongarão em avanços na espécie (2004, p.23). A liberdade - aqui tomada como um estado a ser alcançado pelos homens tomados coletivamente - que depende de um progresso da razão não se realizará no homem que temos diante de nós, mas terá nele apenas uma das etapas que levará à realização da intenção da natureza, por isso que é possível inferir que cada tentativa representaria o esforço por vencer uma nova etapa na conquista da liberdade que é seguida geração por geração. Tal exercício depende desta transmissão geracional destes elementos culturais que permitirão o pleno exercício da razão que parece imbricado no exercício da liberdade e da autonomia.

Tal progresso - segue a tese kantiana - não depende de nada exterior e o homem encontra em si aquilo que lhe foi transmitido pela natureza que nada faz em vão. Por um lado, o homem não deve se contentar em apenas seguir seus impulsos instintivos, mas desenvolver suas potencialidades de maneira que ultrapasse completamente tal estado de coisas. De outro, deve extrair de si tudo aquilo que deve ser atualizado a partir das potencialidades naturais das quais foi dotado.

Assim encaminhamos a tese que considero estratégica, para os intentos deste trabalho: é necessário um antagonismo de disposições para que haja um desenvolvimento das potencialidades propriamente humanas, que não ocorrerão de modo instintivo, o que é intenção da natureza.

Desta maneira, encontramos nesta expectativa formativa do homem que deve sair do estado de menoridade, assim como dar os primeiros passos da "brutalidade para a cultura" 
(2004, p.26) este caráter dúplice da natureza humana. Aquilo que caracteriza o homem quando tomado por um desígnio formativo seria não uma natureza homogênea a ser conduzida por um projeto, mas caracterizado por duas disposições ou propensões que devem protagonizar um antagonismo fundamental para o desenvolvimento humano, portanto, de sua formação.

Se por um lado o homem é propenso à socialização com seus semelhantes, por outro também se inclina por um princípio antissocial de conduzir as coisas tal como a sua vontade, opondo-se aos demais. Kant parece nos sugerir que caso fosse próprio do homem somente o prazer pela socialização, o homem nunca sairia daquele estado natural indolente, permanecendo todas as suas potencialidades para sempre adormecidas; este homem seria pouco mais que instinto. Caso fosse somente antissocial e aguerrido, a permanência das disputas e conflitos impediria o homem de sair de sua rudeza natural e nada de permanente haveria, senão o conflito. São as duas disposições em oposição que obrigariam o homem a colocar em desenvolvimento aquilo que a natureza nele projetou. Os talentos e gostos só se desenvolvem porque o homem anseia medir-se com os demais e se elevar diante destes. Será o esforço por se destacar que levará os homens a criação de suas obras e a manifestações de gênio, que podem ser legadas às demais gerações e a outros povos. Aquilo que surge movido por um princípio de isolamento e dissocialização têm em seu anverso a conservação dos laços que permitem a comunidade entre os homens e seu progresso contínuo intentado pela natureza.

O antagonismo se daria em dois momentos: um interior ao homem tomado como indivíduo, nesta dupla inclinação, e outro na sociedade. Se a cada homem, tomado individualmente, as duas inclinações o levam a caminhos opostos, em seu convívio social ocorre o mesmo: competição e cooperação se digladiam e se filiam. Tal antagonismo tem intenção única, o progresso no uso da razão que deve, em seu tempo, esclarecer a toda a humanidade.

Deste modo, cabe formular a pergunta: como os homens concorrem para este fim, dada esta estrutura teleológica? Ao aproximarmos a discussão deste texto com aquele que tenta definir o esclarecimento, lembramos que o homem não vai de encontro ao seu verdadeiro destino, em um primeiro momento, por falta de resolução e em um segundo momento, por privação de liberdade. Kant é claro ao dizer que é quase inevitável que um 
público se esclareça ${ }^{14}$, ainda que para o homem, tomado individualmente, seja difícil. Os aspectos teleológicos voltam a se destacar. O uso livre da razão ou do entendimento não se opõe às obrigações colocadas aos homens, que vão ampliando o uso público da razão. Razão que se coloca no devido lugar em seu uso público diante do mundo letrado, sabe o papel que lhe cabe e não opta pelo caminho que excede seu raio de atuação. Daí a também famosa passagem deste texto em que Kant minimiza o alcance de uma revolução que derrube o despotismo, se ela não vier acompanhada de uma reforma do pensar que se ocupe de remover os preconceitos que são os verdadeiros empecilhos a impedir a saída da menoridade e do livre desenvolvimento das potencialidades humanas. Em suma, bastaria a razão encontrar o espaço de atuação que lhe é próprio para que tudo se desenvolva tal como designado pela natureza.

A ideia de formação que parece aqui estar indicada é a do encontro do homem com aquilo que a natureza o dispôs. Suas potencialidades se desenvolverão se o homem souber fazer o uso adequado da razão ${ }^{15}$ para além de seus impulsos instintivos, e encontrar os embates que deve travar. Desenvolvimento que é lento e processual, talvez até imperceptível, o que é característico quando se tem em vista a dimensão teleológica.

Estes traços de autoformação do homem, que tentamos aqui esquadrinhar nos textos de Kant, parecem estar de maneira geral já indicados por Quintale Neto: a meta a ser perseguida seria uma unidade do sujeito com certa ideia de natureza. Homem indo de encontro a si mesmo de acordo com um telos que se desenvolve lenta e imperceptivelmente, à medida que se aparte das bruscas transformações revolucionárias.

Creio também ser interessante ressaltar a estrutura que parece constante nestas propostas formativas: duas propensões naturais antagônicas. O que chama atenção no caso de Kant - que como veremos não irá se repetir em Schiller e em Nietzsche - é que tal

\footnotetext{
${ }^{14}$ Foucault (2005, p. 338) nota a ambiguidade do texto em questão, pois nele o esclarecimento é tanto um fato ou um processo em vias de se desenrolar quanto uma tarefa. Essa ambiguidade parece se repetir de maneira bastante próxima a da "Ideia de uma história universal...".

${ }^{15}$ Sobre o que chamamos aqui de uso adequado da razão, Foucault $(2005$, p. 338,339$)$ parece ter notado bem que o uso livre da razão está circunscrito ao que poderia ser chamado de interesse público, para além das finalidades privadas de cada indivíduo, e que, portanto, há uma finalidade comum a humanidade, uma vez que deve estar cada um apto ao uso livre da razão libertos do estado de menoridade. O uso da razão, segundo Foucault seria bastante específico: "É preciso observar que a palavra alemã aqui utilizada é razonieren: esta palavra (...) não se relaciona com um uso qualquer da razão, mas com um uso da razão no qual esta não tem outra finalidade senão ela mesma: razonieren é raciocinar por raciocinar. E Kant dá exemplos, eles também completamente triviais, aparentemente: pagar seus impostos, mas poder raciocinar tanto quanto se queira sobre fiscalização, eis o que caracteriza o estado de maioridade;"
} 
antagonismo não corre riscos de ser desarmônico. Kant não prevê - ou ao menos opta por não colocar tal hipótese em exame - a possibilidade de predomínio de uma disposição frente à outra. Kant não olha para seu tempo ou para o passado de maneira a dizer se os homens estão seguindo mais uma ou outra propensão. Não se trata de apontar uma brecha que possa ser uma falha ou fraqueza da argumentação, mas tentar encontrar os limites em que nos movemos para encontrar o que há de específico na elaboração sobre a ideia de formação em cada um destes importantes escritos. Antes, importa notar que tal antagonismo de propensões talvez não seja uma luta por predomínio, mas um esforço no sentido de uma harmonização. Isto pode indicar que a impossibilidade de uma propensão se sobressair sobre a outra não estaria nos planos da natureza para os homens.

Sigo neste momento para a obra de Schiller, “A Educação estética do homem”, cujo projeto para uma formação do homem é tratado de maneira mais nítida. Em primeiro lugar, voltemos a atenção para o título que traz em si o termo educação - em alemão Erziehung cujo significado nem sempre é tão distinto do de Bildung. Ainda que este último termo apareça, assim como outros dele derivado, variadas vezes ao longo da obra ${ }^{16}$.

Na obra, é nítido como quase toda a argumentação decorre do antagonismo de impulsos ou forças em oposição: o sensível e a razão, homem físico e homem moral, material e formal, natural e ético, entre outras que variam a partir do mesmo pressuposto. Tal antagonismo é central nas teses expressas nas cartas de Schiller e serão de importância vital para entendermos de que modo propõe uma formação para o homem.

Antes de analisar tal tensão, é necessário fazer alguns apontamentos. Já na segunda carta, encontramos uma importante tarefa que Schiller julga ter sido legada à investigação filosófica, a saber: a realização da maior das obras de arte, "a construção de uma verdadeira liberdade política" (2003, p.23). Neste mesmo imperativo encontramos conjugados política, filosofia e arte. Nada mais belo a ser almejado do que a liberdade política. Caberá a qual gênio da arte a responsabilidade de realizar tal obra senão a Filosofia em seu caráter investigativo? O interesse para esta realização não se restringiria a poucos homens, mas diz respeito a todos aqueles dotados de livre pensar. No entanto, uma advertência: estariam certos

\footnotetext{
${ }^{16}$ São 36 ao todo as aparições do termo Bildung e de suas variações, as mais frequentes Ausbildung e Einbildungskraft. No entanto o termo original aparece somente três vezes. Curiosamente o termo Erziehung somente aparece, para além do titulo, em duas notas de rodapé.
} 
o filósofo e o homem do mundo, que julgam ver na arena política o cenário onde se joga o grande destino da humanidade? Schiller parece apontar outro caminho. O ponto chave parece estar em uma relação que é tecida entre homem, natureza e Estado. Este último, por ser decorrente do artifício humano talvez esteja um pouco deslocado em tal relação. A realização desta grande obra não poderá ser realizada por qualquer um, nem mesmo pode se depositar esta esperança no Estado - que em sua forma atual teria até mesmo originado o mal (2003, p.43) - e deveria ter sua reforma fundamentada neste novo homem. O campo que Schiller considera estratégico para formar a humanidade se encontra nas Belas Artes.

Qual é este artista que empreenderá tal tarefa? Para Schiller (2003, p.30), tanto o artista mecânico como o artista do belo empreendem a ação de moldar, dar forma a uma massa amorfa, de uma maneira que pode ser violenta, mesmo que o artista do belo recorra ao uso de artifícios como a sutileza ou o trato, para ocuparem o lugar da violência que de fato ocorre. Mas o artista aqui convocado é o artista pedagogo e político, que terá outro tipo de cuidado, uma vez que é o homem o seu material e tarefa, o cuidado requerido se deve ao fato de que os efeitos de sua arte não podem passar por ilusórios.

Lembremos que é este artista, ou esta noção de arte, que estariam encarregados da formação cultural ${ }^{17}$ (Bildung) do homem, de forma que:

\begin{abstract}
Daí ser sempre testemunho de uma formação cultural ainda precária se o caráter ético só se afirma com o sacrifício do natural; e é ainda muito imperfeita uma constituição do Estado que só seja capaz de produzir a unidade pela supressão da multiplicidade. O Estado não deve honrar apenas o caráter objetivo e genérico nos indivíduos, mas também o subjetivo e específico; não deve, ao ampliar o reino invisível dos costumes, despovoar o reino dos fenômenos. (2003, p.30)
\end{abstract}

Aqui, vemos uma porção de pólos antitéticos: ético e natural, unidade e multiplicidade, objetivo e subjetivo, genérico e específico, costumes e fenômenos. Caso estes pares não recebam o devido tratamento deste artista pedagogo/político, não será possível alcançar uma adequada formação cultural para o homem. Trataremos mais adiante destes pólos em oposição com o cuidado devido.

\footnotetext{
${ }^{17}$ Procurarei sempre indicar o termo original da língua alemã utilizada, dada a polissemia do termo, como já indicado. Outros termos que nutrem algum tipo de relação semântica com aquele poderão também ser indicados como Kultur ou Ausbildung.
} 
Sabemos que a principal motivação do texto de Schiller foi a fase do Terror propiciada pelos jacobinos vitoriosos e hegemônicos na disputa com os girondinos pela sorte das decorrências da Revolução Francesa. As cartas de Schiller se dão neste contexto em que temos o conhecimento de sua simpatia pelos girondinos. Se estivermos desprovidos destas informações, perceber tal motivação no texto não é algo óbvio. Ou seja, o texto não expressa de modo direto as escolhas e visão política do filósofo naquele contexto histórico. Por isso o propósito que creio reter maior valia é o de pontuar bem qual diagnóstico o autor consegue formular para dar expressão aos motivos pelas quais a Revolução Francesa não teria alcançado a importante missão que aqui é colocada para a investigação filosófica. Creio que este diagnóstico pode ser bem ilustrado em dois pontos: em primeiro lugar, a fragmentação do homem moderno propiciada pela cultura, apontamento em que se requer o frequente modelo de comparação com o homem grego. O segundo ponto, que talvez seja a causa do primeiro, uma incompreensão sobre a relação entre humanidade e Estado. A reforma do Estado não está fora de cogitação, mas não pela sua destruição ou substituição. Trata-se de reformá-lo enquanto pulsa, uma vez que a verdadeira transformação deve incidir verdadeiramente sobre o homem. Disto apontamos duas consequências ou efeitos, que foram percebidas nos estudos sobre a Bildung aos quais fizemos referência na parte inicial deste capítulo. O primeiro ponto seria uma oposição entre política e a arte, se os alemães se sentem mais confortáveis no domínio da arte, o que pode ser entendido como uma posição mais conservadora por estar mais voltada à contemplação e menos afeita à ação política, que seria o caso dos franceses (WEBER, 2006, p. 118, 119). O segundo ponto é a ideia de que a Bildung depende de um longo processo de transformações contínuas e pouco perceptíveis, que seriam opostas à ideia de uma brusca transformação advinda de uma revolução ${ }^{18}$. O diagnóstico levaria à inferência de que a Bildung transcorre em um tempo próprio, talvez ainda a ser forjado, mas sem a exigência de que os ponteiros sejam recolocados no ponto zero. Os novos tempos não formarão novos homens, pelo contrário, estes serão uma pré-condição dos novos tempos. Assim, observemos que afirmar que A é pré-condição de B não é o mesmo que afirmar que A é causa da consequência B.

\footnotetext{
${ }^{18}$ De modo análogo, já examinamos de que maneira em Kant os efeitos de uma revolução que busca dar fim ao despotismo tem seus efeitos minimizados se não centrarem seus esforços em uma reforma que atue sobre o pensamento dos homens. Assim como foi discutido sobre a Bildung nos romances de formação, os efeitos da jornada formativa do herói se manifestam de maneira lenta, progressiva e quase imperceptível.
} 
As propostas de formação do homem, não raro, se desenvolvem a partir de um pessimismo frente à condição atual. A caracterização da condição do homem de seu tempo, feita por Schiller (2010, p. 37), seria a de uma vida fragmentada ${ }^{19}$ :

Este dilaceramento que arte e erudição introduziram no homem interno foi aperfeiçoado e generalizado pelo novo espírito de governo. Certamente não se podia esperar que a organização simples das primeiras repúblicas sobrevivesse à singeleza dos primeiros costumes e das relações primevas; mas, em lugar de ascender a uma vida animal superior, ela degradou-se até uma mecânica vulgar e grosseira. A natureza de pólipo dos Estados gregos, onde cada indivíduo gozava de uma vida independente e podia, quando necessário, elevar-se à totalidade, deu lugar a uma engenhosa engrenagem cuja vida mecânica, em sua totalidade, é formada pela composição de infinitas partículas sem vida. Divorciaram se o Estado e a Igreja, as leis e os costumes; a fruição foi separada do trabalho; o meio, do fim; o esforço, da recompensa.

Uma ferida é aberta na vida dos homens, da qual a responsável é a cultura (Kultur). Tal fragmentação apontada indica algo sobre a relação entre homem e natureza, como referência para homogeneidade. Aí é que surge a comparação com o homem grego, que não é entendido como vítima do mesmo dilaceramento (2010, p. 35,36$)$. Se foi a cultura moderna que irrompeu esta ferida, seria a cultura grega reflexo de um todo integrado? Schiller aponta que a relação entre a natureza e o homem grego se dava em um patamar diferente. Os gregos aqui são tidos tanto como ideal ${ }^{20}$ quanto rivais. É neles que os modernos deveriam se espelhar assim como devem buscar superá-los ou ao menos alcançá-los ao máximo. Ao contrário dos modernos, os gregos não opõem seus sentidos ao seu espírito e podiam reunir em si a juventude da fantasia e a virilidade da razão. Tamanha seria a força que este povo retira da natureza unificada, que permitiu o autor ver em cada indivíduo grego um digno representante do seu tempo sempre disposto a se colocar em luta pelo destino da humanidade.

Tal unidade não poderia ser encontrada no homem moderno, que por vezes se vê refém da faculdade analítica, que faz do pensador abstrato um homem de coração frio que só percebe o todo em suas partes desmembradas, o que o impede de ter sua alma comovida. Não diferente seria para o predomínio do homem de negócios, cujo coração estreito se encontra

\footnotetext{
${ }^{19}$ Pelo ponto de vista que aqui apresentaremos, Nietzsche parte do mesmo ponto, mas não necessariamente da mesma caracterização do homem moderno.

${ }^{20}$ A noção de Ideal em Schiller não pode passar despercebida para os intentos desta pesquisa. Se utilizo em tantos momentos a expressão "ideal de formação" não é por acaso, o que deve ser esclarecido em outros momentos do trabalho. Para Schiller, o Ideal seria, de acordo com nota de Marcio Suzuki (2010, p. 142), uma ideia inalcançável e também modelo.
} 
encarcerado na monotonia de sua ocupação. Schiller reafirma tal tese com o argumento de que a maior parte dos homens desenvolve somente parte de suas potencialidades.

Para Schiller é o antagonismo destas duas forças que deve ser estímulo e alimento da ação da cultura. O problema encontrado no homem moderno não é a luta destas duas forças, mas o predomínio e isolamento de uma delas.

Assim, a mesma cultura que abre a ferida ${ }^{21}$, que divide o homem, é chamada ao socorro para mediar ou operar tal antagonismo. Este antagonismo, podendo acarretar o isolamento de uma força em relação à outra, é desejável ainda que leve o indivíduo inevitavelmente ao erro. Daí temos o momento em que tais formulações schillerianas se mostram semelhantes às kantianas descritas anteriormente ${ }^{22}$. Por mais que o erro ocorra com certa frequência no indivíduo, leva a espécie à verdade.

Será então este progredir contínuo da humanidade em busca da verdade que servirá de fundamento ao Estado. A entronização da lei que tem a consagração da liberdade como fundamento do vínculo político (2010, p. 33) depende da formação do homem cujo recurso será buscado nas Belas Artes, instrumento não fornecido pelo Estado (2010, p. 47).

Como já indicado, Schiller (2010, p. 43) considera que o aperfeiçoamento moral do Estado depende necessariamente da condição moral do homem. Da mesma maneira que a força do homem grego era retirada da natureza unificada, é também na natureza, entendida como criação física, que poder-se-ia encontrar um caminho para a criação moral. Tanto no caráter ético quanto no físico, torna-se imperativo para a formação (Bildung) um apaziguamento das forças elementares. Sem esta ação formadora, qualquer reforma no Estado não acarretaria os efeitos desejados, por mais liberais que fossem os princípios motivadores destes reformadores ${ }^{23}$. Estes estariam impedidos pelo caráter dos homens que encontrariam "suas forças ainda em fermentação". Se a oposição entre tais forças ainda não tiver recebido o tratamento adequado pelo qual a formação agiria ainda teríamos um homem natural abusando de seu arbítrio de forma desregrada, sem poder lhe mostrar liberdade e o homem artificial impedido de usar sua liberdade sem que lhe seja conferido arbítrio. Assim, “(...) antes que se possa submeter sua multiplicidade à unidade do Ideal, é preciso que a autonomia de seu

\footnotetext{
${ }^{21}$ Ainda que o entendimento, para Schiller, seja caracterizado como o impulso que a tudo separa.

${ }^{22} \mathrm{O}$ fato de a formulação desta sexta carta de Schiller se assemelhar bastante da quarta proposição de Kant, que já discutimos, em Ideia de uma história universal de um ponto de vista cosmopolita é percebido por Marcio Suzuki, autor das notas e introdução da edição da obra de Schiller, que aqui utilizamos (2010, p. 142).

${ }^{23}$ Importante notar a reincidência deste aspecto da Bildung contrário às bruscas transformações sejam elas revolucionárias, sejam elas feitas pelo aparelho de Estado.
} 
caráter esteja assegurada e que a submissão a formas estranhas e despóticas tenha dado lugar a uma liberdade decorosa".

É mister perceber que Schiller (2010, p. 43) não deposita esperança na Filosofia para resolver tal impasse. Por mais ilustrada que seja a sua época, em que a razão teria destruído conceitos ilusórios e a investigação encontrado cada vez mais solo para a descoberta da verdade, a Filosofia ainda convive com o preconceito e a ignorância.

Há assim uma impotência, ou insuficiência, da Filosofia enquanto instrumento formador, o que abre espaço para a atuação das Belas Artes. Estas seriam o instrumento para a formação (Ausbildung) da sensibilidade, uma vez que seria o coração que deveria abrir o caminho para o caráter, não podendo ser imaginável qualquer melhora desejável do entendimento que não influa sobre o caráter.

Ainda assim, esta educação para a sensibilidade não é somente tarefa da arte: o filósofo se ocupa tanto quanto o artista de tentar trazer beleza ao vulgo. Há aqui um certo idealismo na concepção de arte e ciência, que as colocariam em oposição ao $\operatorname{Estado}^{24}$, ou ao menos em posição de imunidade à sua ação. Aquelas tendem ao que há de mais eterno e necessário à natureza humana, e portanto seriam incorruptíveis, ao contrário do Estado, que é fruto das convenções e arbítrio humano. Somente estas, e em especial as artes, poderiam se ocupar da busca pelo Ideal em que seria possível conjugar o possível com o necessário moldando a ilusão e a verdade nos jogos da imaginação e da seriedade.

Não há república sem um homem formado e autônomo, não há expectativa de transformação da natureza do homem através do ordenamento estatal. É a autonomia do homem, este princípio iluminista maior que recai sobre a Bildung, que se coloca como norte principal. Uma vez assegurada a realização deste princípio, as questões sobre o Estado podem ser colocadas.

Uma questão chave ainda falta ser mais bem tratada aqui, que é a duplicidade de impulsos que se colocam em oposição na natureza do homem e que move todo o escrito de Schiller. Falávamos, no momento anterior, desta repartição entre um homem natural e um artificial, ou de uma criação física, oposta a uma moral. Já na primeira das cartas é introduzida

\footnotetext{
${ }^{24}$ É possível entender que o projeto humboldtiano de universidade parta desta mesma premissa sobre o Estado.
} 
a oposição entre o sensível/aparente e a razão/conceitual. Tal duplicidade de impulsos ou de caráter, o duplo homem que fundamenta a natureza da humanidade, se espraia ao longo de quase todas as cartas. Mas será principalmente da décima primeira a décima quinta carta em que esta oposição tomará os traços que considero fundamentais para discutir a formação.

Os dois impulsos primordiais presentes na natureza humana seriam o sensível e o formal (2010, p. 59). Desta oposição, parecem decorrer todas as outras descritas e comentadas na obra. Do primeiro impulso, entendemos tudo aquilo que é existência física, natureza sensível, matéria entendida como modificação ou simplesmente realidade. O segundo impulso deve ser entendido como existência absoluta, natureza racional que se empenha pela liberdade e pela harmonia da multiplicidade dos fenômenos.

Voltemos a uma oposição presente na décima carta, que se refere à distinção entre pessoa e Estado (2010, p. 55 e ss). A primeira é entendida como aquilo que permanece em si mesmo, o segundo aquilo que está sujeito a modificações e seriam as determinações deste em si mesmo. Duas instâncias que são unas no ser infinito, mas não no ser finito.

Portanto, o homem tem, primeiramente, de receber a matéria da atividade ou a realidade (que a inteligência suprema haure de si mesma), e ele a recebe, pela via da percepção, como algo existente fora dele, no espaço, ou como algo alternante nele, no tempo. Essa matéria que nele alterna é acompanhada por seu eu que nunca alterna - e permanecer sempre ele mesmo em toda sua alternância, isto é, fazer das percepções a experiência, a unidade do conhecimento, e de cada uma das espécies de fenômeno no tempo a lei de todos os tempos, esta é a prescrição que lhe é dada por sua natureza racional. Na medida somente em que se modifica, ele existe; na medida somente em que permanece imutável, ele existe. O homem, pois representado em sua perfeição, seria a unidade duradoura que permanece eternamente a mesma nas marés da modificação. (2010, p.56)

Ora, do impulso formal temos este reclame pela unidade ao qual o entendimento tenta dar unidade, e também a necessidade daquilo que é real. Para Schiller, esta tendência teria algo de divino a tentar reclamar real todo o possível, e necessário todo o real. O homem teria em si uma disposição para a divindade que não pode cumprir.

Desta concepção é que Schiller fundamenta as duas tendências e leis fundamentais da natureza sensível-racional do homem. Uma que demanda realidade absoluta e a outra formalidade absoluta. Uma se dispõe a fazer efetiva toda forma, e outra, a introduzir coerência em todas as modificações. 
Vamos adiante: se o impulso sensível só trata de casos, o impulso formal exige leis. Uma vez que exige-se do real que seja necessário e eterno, e que o eterno e necessário sejam reais, segue-se como consequência uma exigência por verdade e justiça. As leis requeridas pelo impulso formal deveriam se constituir em juízos ou vontades. Notemos que podemos diferenciá-las - o que deverá ser útil mais adiante - em enunciados denotativos e prescritivos respectivamente.

Aqui entra em ação um terceiro impulso, que parece ter sido formado pela sensibilidade ou educação estética. Se só existe casualidade no sentimento no qual a verdade não assentaria pés nos diversos casos, sendo sempre modificada, o pensamento, por sua vez, só encontra verdade no absoluto. Ali provisoriedade e relatividade permanecem, aqui somente necessidade. De um lado um enunciado denotativo hipotético, de outro somente denotativo.

O terceiro impulso visa a conciliação através de um sentimento moral que anuncia um dever ser. $\mathrm{O}$ enunciado prescritivo que quer tomar a forma de lei. Do caso singular alcança-se a regra para todos. O juízo que atingirá a todos os espíritos agora pronunciado pelo nosso (2010, p.61).

Se percebermos que a discussão sobre a formação mostra contornos nítidos nos textos abordados de Kant e Schiller, de maneira que não é difícil notá-los e perceber de que maneira ainda permeiam nosso pensamento educacional, o mesmo não poderia ser dito, de maneira tão simples e óbvia, do "Nascimento da tragédia" escrito por Nietzsche.

Para além do fato da obra não ter a mesma inserção histórica que as outras, o que já dificulta a relação com a Bildung, tão atrelada ao Iluminismo, a discussão proposta pelo autor estaria centrada em um problema de ordem estética, a saber a maneira que surge e se expressa a tragédia grega. No entanto, o modo pelo qual tal discussão é feita pode trazê-la mais próxima de nosso interesse.

Já falamos como a formação é também encontro com o estranho e com o estrangeiro, ou com a alteridade em seus planos temporal e espacial. O modelo, e de certa forma um rival como aponta Schiller, seja para imitação ou comparação é quase que invariavelmente o homem grego. O alemão em busca de si decide recorrer ao grego antigo. O interesse específico em uma forma artística como a tragédia por Nietzsche não deixa de lado tal interesse. 
Creio não ser possível inferirmos de maneira direta, dessa obra, que Nietzsche pensa na formação de um novo indivíduo ou do povo alemão a partir dos gregos como modelo. Mas ao partir deste modelo, é possível para o autor melhor configurar e compreender seus contemporâneos. Podemos recorrer à imagem do estranhamento no aforismo 355 de Gaia Ciência, e sua difícil tarefa de estranhar aquilo que é tão terrivelmente habitual (2007, p. 251). Ali Nietzsche advertia: "o familiar é o habitual; e o habitual é o mais difícil de "conhecer", isto é de ver como problema, como alheio, como distante, "fora de nós"..." De maneira análoga, penso que a partir do exercício proposto por Nietzsche de se colocar o alemão moderno ao lado do grego antigo, podemos entender melhor quem é este familiar estranho com o qual Nietzsche convivia, mas que seria tão difícil de perceber de fato.

Não é a toa que Nietzsche tem em tão pouca estima a arte de seu tempo, assim como os valores que guiam os estetas modernos. Aliás, neste ponto, não haveríamos de estranhar que há concordância em algum grau com o modo com que Schiller se volta para os gregos. Toda cultura posterior teve que com eles se medir (2008, p. 39): sempre nos sentimos apequenados nesta tentativa de comparação com este povo, que teve a audácia de nomear tudo aquilo que fosse estranho ou estrangeiro de bárbaro. Todos que vão aos gregos, para tentar imitá-los ou superá-los, cultivam esta imagem de um povo autossuficiente, figura plena de autonomia que cultivou a si próprio, com suas próprias forças, sem recorrer a modelo anterior algum. A despeito da veracidade ou falsidade desta assertiva, nem mesmo Nietzsche pode destoar tanto assim deste juízo, ainda que mais atento e guardando devidas suspeitas, se comparado a um Schiller, muito mais entusiasta dos gregos com sua cultura.

Ora, se no autor das "Cartas" encontramos os dois impulsos fundamentais que encerram o conceito de humanidade, podemos dizer que o mesmo acontece com os impulsos fundamentais da expressão artística para Nietzsche, o apolíneo e o dionisíaco? Para tanto, requer-se cautela. Não se trata de ver nestes dois impulsos uma dupla fundamentação do homem ou do humano, em um primeiro momento ou à primeira vista. Também não concluamos que tais impulsos nutram entre si a mesma relação dos schillerianos ou daquelas propensões encontradas por Kant no homem.

Assim colocada a questão, encaminhemos o seu exame, não sem uma nota prévia: a relação entre arte e vida ${ }^{25}$. É na arte, e somente nela, que a vida vale a pena ser vivida. $\mathrm{O}$

\footnotetext{
${ }^{25}$ Nietzsche é habitualmente visto como um pós-moderno extemporâneo, ou como o autor que anteviu a fragmentação pós-moderna que não poderia mais reclamar daqueles tempos em que as esferas vitais pareciam
} 
filólogo diz mais: somente à mercê das artes, do sono e do sonho é que "a vida se torna possível e digna de ser vivida" (NIETZSCHE, 2008, p. 26). Apolíneo e dionisíaco antes de serem parte da natureza humana, como os impulsos schillerianos, estão relacionados ao contínuo desenvolvimento da arte em que estariam em luta incessante com eventuais reconciliações.

Como caracterizar estes dois impulsos antagônicos que em larga escala movem todo o pensamento de Nietzsche sobre a tragédia? Em primeiro lugar, notemos que Apolo e Dionísio tem íntima relação com a arte no imaginário helênico (2008, p. 24). O primeiro é tido como o artista da figuração plástica, enquanto o segundo representaria a arte não figurada da música. Uma segunda contraposição se encontra nas manifestações destas duas potências: o sonho e a embriaguez.

Por um lado, o sonho seria a pré-condição de toda arte plástica. A experiência onírica, a partir da inspiração de Apolo, assume para os gregos a necessária contraposição à realidade cotidiana. Por outro lado, temos a embriaguez como a essência do impulso dionisíaco. Embriaguez que não depende somente da beberagem narcótica, mas também do canto e da dança em que o subjetivo cede a um autoesquecimento. Estes transportes dionisíacos, além de nos retirar do jugo da realidade cotidiana, reconciliariam os homens à natureza e ao misterioso Uno-primordial: "Agora, graças ao evangelho da harmonia universal, cada qual se sente não só unificado, conciliado, fundido com o seu próximo, mas um só (...) (2008, p.28)”.

No dionisíaco, o homem se torna obra de uma instância maior. No apolíneo, escapa à realidade cotidiana assumindo as vestes de um artista plasmador ou configurador. No apolíneo temos a noção do princípio de individuação (principium individuationis) que Nietzsche toma de Schopenhauer. O homem individual, calmo e confiante de suas limitações frente ao incerto mundo fenomênico, mesmo que a qualquer momento possa ser tomado pelo terror de que a aparência dos fenômenos excetue o princípio da razão que não consegue se fazer regra. Em ambos os impulsos, temos uma relação com a realidade cotidiana de não aceitá-la por completo, ou não aderir aos seus ditames, mas se colocar de modo 'polêmico' em relação a ela. Seja na fuga para o mundo particular do sonho, seja na fusão a uma multidão que se esquece de suas individualidades.

perfazer uma unidade. Curiosamente, a imagem que tal texto nos oferece é a da busca de uma certa integração entre arte e vida, marca forte dos intentos modernos na arte. 
Assim, tais impulsos seriam nada mais do que poderes artísticos irrompidos da própria natureza, que satisfazem e nutrem toda arte dos homens.

Atentemos que no transcorrer da obra o autor está especialmente alerta para os momentos em que um impulso se efetiva como predominante ao outro, a partir da interpretação de diferentes momentos da arte e da tragédia gregas. Os gregos estão ainda colocados como modelos diante do alemão contemporâneo a Nietzsche. Por isso é preciso reforçar sobre algo que ele teria podido perceber nos gregos. Estes puderam conhecer os temores e horrores do existir.

(...) De que outra maneira poderia aquele povo tão suscetível ao sensitivo, tão impetuoso no desejo, tão singularmente apto ao sofrimento, suportar a existência, se esta, banhada de uma glória mais alta, não lhe fosse mostrada em suas divindades? $\mathrm{O}$ mesmo impulso que chama arte à vida, como a complementação e o perfeito remate da existência que seduz a continuar vivendo, permite também que se constitua o mundo olímpico, no qual a "vontade" helênica colocou diante de si um espelho transfigurador. Assim, os deuses legitimam a vida humana pelo fato de eles próprios a viverem - a teodicéia que sozinha se basta! (2008, p.34).

Um e mesmo impulso exige a representação artística e a criação do mundo divino, se é que as duas instâncias podem ser de fato apartadas. Um existir que só é suportado quando convive com tais instâncias, sem as quais dificilmente poderíamos atribuir a ele algum sentido. Poderíamos entender com isso algo análogo ao diagnóstico schilleriano, de que o grego retira suas forças da natureza unificada? Se este estado pode ser pensado, ele não foi atingido de modo simples ou espontâneo, indica Nietzsche (2008, p. 35). Não há ingenuidade na arte grega, adverte o filólogo a Schiller, a bela aparência que o apolíneo logra não se dá sem o confronto com perigosos Titãs, monstros e poderosas alucinações. Não há, portanto, harmonia pressuposta entre homem e natureza, mas relação tensa e turbulenta que acarreta em sofrimento, excitação de desejos e uma peculiar sensibilidade que encontra nas potências do sonho e da embriaguez ao mesmo tempo refúgio e fortaleza. O homem grego de Nietzsche não parece se mover para o domínio da natureza das coisas e/ou de si próprio, mas suportando a existência, e aprendendo a viver a partir dele, tal e qual sua cultura permite e exige.

Apolo é também a divindade da medida, do autoconhecimento (2008, p.37). Para que a individuação predomine, ela deve se manifestar como imperativo e prescrição, deve se colocar, como lei, em enunciados tais como: "conhece-te a ti mesmo" e "nada em demasia" que se colocam em oposição radical à autoexaltação e ao desmedido. Assim tudo que era visto 
como estranho a este espírito apolíneo era tido como bárbaro ou titânico, ou seja, aquilo que é provocado pelo dionisíaco. Mas o parecer de Nietzsche sobre esta luta entre impulsos é de que um não possa viver sem o outro, por mais que um possa se mostrar predominante em face do outro, em diferentes etapas do desenvolvimento da arte grega.

Deste modo, de que maneira pensar a questão da formação, a partir destas considerações destes dois impulsos nesta obra de Nietzsche? Na comparação com o homem grego temos esta forte admiração da maneira em que lida com a sua existência. O modo de vida do grego se coloca como algo a ser notado, ali a sua existência é reconhecida em suas expressões de horror e desamparo. A criação artística realiza-se em tais configurações, pois foi a estratégia que este povo alcançou, não para suavizar os horrores ou encontrar um sentido anterior ou prometer um conforto posterior, mas para dar à vida a dignidade devida.

Tenderíamos a ver em Nietzsche que o que se espera do homem de seu tempo - o que não é o mesmo, mas suficientemente próximo de um intento formativo - é um retorno a um dionisíaco que se tornava mais ofuscado por um predomínio do apolíneo, pela via do que ele chamava de socratismo. A predominância do escape individual teria afastado dos homens a relação com o ser primordial que a todos une pela embriaguez. Repito: não se trata de identificar na natureza humana uma propensão essencial ao sonho e a embriaguez, mas arrisco dizer que tais instâncias complementares e opostas seriam necessárias em uma vida que reconhece a ação humana pela arte como a única via que desenvolve as potencialidade pelas quais a vida pode ser afirmada e devidamente vivida, e fazer dos homens verdadeiramente homens.

Mas podemos ir um pouco além e notar um aspecto específico do apolíneo e do dionisíaco, algo próximo ao antagonismo presente no texto "Ideia de uma história universal." de Kant. A tendência de individuação do apolíneo, o refúgio no mundo individual não compartilhado do sonho, que é um chamado à medida, a um dever-ser que toma a forma da lei, pode ser aproximado da propensão antissocial. Da mesma maneira, o festim na embriaguez, recusando a individualidade na tentativa de união e retorno ao uno primordial pode se aproximar à propensão por socialização. Ainda que os motivos que levem a tais formulações sejam suficientemente distintos, assim como o sejam os propósitos de cada obra, o caminho percorrido é bastante similar o que talvez faça com que a oposição de impulsos ou propensões tome forma análoga. 
Por via não muito diferente podemos também contrapor Schiller a Nietzsche, ou ao menos fazer uma breve comparação. O termo formação não pode ser usado em sentido rigorosamente idêntico para os dois autores. Mas os intentos se aproximam bastante quando fazem uso do recurso de diagnosticar uma situação de maneira negativa, a ponto de entender como um desequilíbrio de impulsos antagônicos como ponto chave para equacionar tal situação. Em Schiller, as Belas Artes são um caminho para a liberdade política; para Nietzsche, não há vida a ser vivida sem arte, mas esta arte deve ser aquela que leva o homem ao encontro de suas verdadeiras potencialidades, "tornando-se aquilo que se é". 


\section{O ideal de formação e o declínio das metanarrativas na "Condição pós-moderna".}

Ao esboçar um quadro sobre o que pode ser entendido por ideal de formação ou Bildung, um dos seus traços mais característicos deve ser ressaltado, de acordo com os intentos deste trabalho. Trata-se da expectativa de emancipação que recai sobre o ato da formação.

O ideal de formação, sobretudo em sua faceta iluminista ${ }^{26}$, traz esta marca maior que é a da emancipação, seja a de um indivíduo somente, seja a de um povo ou de uma comunidade. Assim notamos que há no discurso iluminista uma aposta na formação do cidadão para que seja possível alcançar a liberdade e a sua emancipação. É neste momento que entra em cena o papel da instituição escolar, que desde o advento da República Francesa, se incumbe de tal tarefa.

(...) A modernidade, as luzes, a própria reflexão kantiana colocaram a escola no centro do interesse popular e prático da razão. Desde há dois séculos, principalmente em França, e também de outro modo na Alemanha, o objetivo desse interesse chamou-se formação do cidadão na república. A tarefa filosófica viu se confundida com a da emancipação.

(LYOTARD, 1993a, p. 123)

Não somente a escola é colocada como o lugar onde a emancipação é esperada para o cidadão na República, como há uma tarefa filosófica para se dar ali. Tarefa que, para Lyotard, passa a ser confundida com a da emancipação.

Pouco interessa aqui examinar esta confusão e seus motivos. Mesmo o autor não se preocupa em ser explícito sobre tal assertiva, a qual não é banal e muito menos desprovida de interesse. Antes, vale marcar que esta associação de formação para a emancipação passa a ser uma tarefa filosófica que se dá justamente na escola. Com isto, podemos dizer que a Filosofia que integra o mundo escolar ${ }^{27}$ está amparada em um objetivo maior, que nada mais é do que o anseio iluminista de "formação do cidadão na república".

Deste modo, o Iluminismo se coloca como um discurso que legitima uma prática que viria a ser desenvolvida pela Filosofia no espaço escolar, a prática que visa à emancipação.

\footnotetext{
26 “O progresso da ciências, das técnicas, das artes e das liberdades políticas emancipará a humanidade inteira da ignorância, da pobreza, da incultura, do despotismo e não fará apenas homens felizes, mas nomeadamente graças à Escola, cidadãos esclarecidos, senhores dos seu próprio destino.” (LYOTARD, 1993a, p. 101).

${ }^{27}$ Aqui pouco interessa discutir se falamos de filosofia como componente curricular ou atuando sob alguma outra forma no contexto escolar.
} 
Iluminismo como discurso de legitimação, como metanarrativa ou metarrelato para recorrermos aos termos amplamente utilizados por Lyotard em “A condição pós-moderna”.

Há portanto narrativas e relatos diversos, mas a partir do advento da modernidade, podemos começar a falar em metarrelatos no sentido de que encontramos neles um valor último de legitimação das práticas sociais, sobretudo a legitimação do saber e da ciência:

(...) as grandes narrativas nas quais se tenta ordenar a enorme quantidade de acontecimentos: narrativa cristã da redenção do pecado adâmico pelo amor, narrativa aufklärer da emancipação da ignorância e da servidão pelo conhecimento e igualitarismo, narrativa especulativa da realização da Ideia universal pela dialéctica do concreto, narrativa marxista da emancipação da exploração e da alienação pela socialização do trabalho, narrativa capitalista da emancipação da pobreza pelo desenvolvimento tecnoindustrial. (...) Mas todos situam os dados que os acontecimentos trazem no curso de uma história cujo termo, mesmo parecendo inatingível, se chama liberdade universal, absolvição da humanidade inteira.

(LYOTARD, 1993a, p. 38,39)

Para além da narrativa iluminista (aufklärer) da qual tratávamos, há outras que ocupam o lugar de uma metanarrativa. Ainda que cada uma possua traços distintivos, todas elas projetam algo a ser realizado que vem a ser um fim universal: emancipação e/ou redenção de todos. Não à toa, Lyotard reforça que é justamente a ideia de emancipação que rege o pensamento e a ação dos séculos XIX e XX (1993a, p.101).

Além deste traço comum a cada um dos conteúdos das narrativas citadas, o que faz de cada uma delas ser considerada uma metanarrativa ou um grande discurso de legitimação é que além de legitimarem diversas ações e práticas, também situam os acontecimentos como favoráveis, ou não, para seus fins.

Se, portanto, a Filosofia e a escola se percebem na tarefa da formação deste cidadão para a República, o que ocorre a partir do momento em que estes mesmos ideais modernos entram em declínio ou até mesmo em descrédito?

No importante e já citado texto "Mensagem a propósito do curso filosófico" (LYOTARD, 1993a, p117-126) encontramos a situação do jovem aluno que passa a frequentar esta instituição que surgiu outrora amparada naqueles fins - e que permanece ainda de alguma forma por eles orientada - mesmo com o declínio da força legitimadora daquelas metanarrativas.

Temos então jovens que são atirados à instituição escolar, mesmo que permaneçam 
estranhos aos intentos formativos que são, ou eram, a razão de ser da escola. Há, assim, uma incompatibilidade entre estes jovens alunos e o curso filosófico, proposto pelo autor, assim como também são estranhos ${ }^{28}$ aos intentos formativos de uma metanarrativa iluminista.

Deixemos de lado por hora a distinção entre o ideal de formação e o 'curso filosófico', se é que existe alguma. No texto citado, encontramos uma incompatibilidade que se dá em termos de linguagem, ou ao menos do uso de dois idiomas ${ }^{29}$ distintos (1993a, p. 125): aquela que o curso filosófico pretende formar no aluno e aquela do mundo que se expressa pela competitividade, sucesso, realização. Um idioma ou fala que se orienta pela troca econômica que tende a se generalizar em todos os aspectos da vida.

Este idioma- que é o que o mundo fala e que também é falado pelos alunos em sala é decorrente do novo estatuto de saber que Lyotard discute em "A condição pós-moderna". O saber estará cada vez mais submetido a um processo de tradução para informação, para uma unidade decodificável e assimilável a esquemas ou padrões classificatórios. O saber passa a ter um novo estatuto, passa a ser cada vez mais produzido para ser consumido e vendido. Assume cada vez mais um caráter pragmático, no sentido em que perde não somente seu valor de uso mas também o valor que teria em si. Deste modo, o princípio que regia a condição de que a aquisição de um saber não pode estar dissociada da formação do espírito daquele que aprende, tende cada vez mais a cair em desuso (2011, p. 4,5).

Assim, acredito ser útil a referência à questão da legitimação proposta por Lyotard

\footnotetext{
${ }^{28}$ Em uma entrevista, Lyotard explicita este estranhamento dos jovens aos fins da instituição escolar, assim como suas estratégias e a comum resposta da escola a estas. "Há actualmente nos estabelecimentos de ensino jovens que não estão lá a fazer nada. Estão lá porque é obrigatório, exatamente como no quartel. Tal como os recrutas, procuram sobretudo iludir os meios da instituição, pelo que parecem estranhos ao fim desta, que é os de os instruir. Parecem antes querer gozar o que está imediatamente disponível. O "pedagogismo" concede-lhes isso. Ele contribui para o fracasso da escola." (1993b, p.51). Para além disso, o autor ainda chama atenção nesta mesma entrevista de como é distante a postura dos jovens na atualidade se comparada aos anseios daqueles que rumavam para a escola ainda na jovem escola republicana: "Não há restauração possível da república. É muito bonito descrever o que deve ser a transmissão de um saber rigoroso, sem concessão, mas é necessário igualmente ter em conta a situação presente nas aulas. Não podemos proceder como se estivéssemos na época das Luzes. Enviava-se o pequeno camponês de Auverne à escola para que ele progredisse no saber, na sociedade e na liberdade. Ele queria-o. Quem é que hoje deseja a escola?" (p.53)

${ }^{29}$ O termo 'idioma' aqui usado nesta carta de 1984, publicada em 1988, aparece antes na obra Le Differend de 1983. Em A condição pós-moderna, publicada em 1979 em sua edição francesa, o termo não é utilizado. Ali termos como 'narrativa', 'discurso' ou 'enunciado' são os mais utilizados. Já em Le Differend termos como 'idioma', 'frase' e 'gênero de discurso' passam a ser amplamente utilizados. O termo é utilizado nesta obra, assim como no texto aqui discutido, de forma vaga sem uma elaboração mais cuidadosa, ainda que seja crucial para entender a noção de 'diferendo' na obra homônima (LANGHELLE in: SIM (org.), 2011, p. 88,89). Por ora, para um suficiente entendimento do termo, vale destacar que diversos idiomas podem ser falados, novos podem ser criados e outros podem deixar de existir. Como veremos mais adiante um idioma pode ser incomensurável ao outro, ou seja, um não pode ser traduzido para outro sem perder sua especificidade ou singularidade.
} 
para entendermos este novo estatuto do $\operatorname{saber}^{30}$ e sua relação com o 'idioma que fala o mundo'. Uma vez que o saber aparenta estar mudando de estatuto no estabelecimento das sociedades pós-industriais, devemos examinar se o princípio de legitimação destes saberes que parecia estar tão bem assegurado antes - também possa igualmente estar sofrendo alguma sorte de abalo. Ora, o autor nota bem a necessidade de distinguir com maior precisão o que entendemos por saber, conhecimento e ciência. Para além do modo como o autor elabora tais distinções, nos importa aqui partir da diferenciação entre dois tipos de saberes: um de tipo narrativo e outro de tipo científico, cada um pressupondo uma pragmática típica. Entende-se que o saber científico busca meios próprios para sua legitimação que devem ser suficientemente distintos daqueles de um saber narrativo ou dos relatos.

Antes de discutir o modo como Lyotard caracteriza o saber científico e o saber narrativo é importante explicar de que modo ele faz uso da noção de jogos de linguagem utilizada em momentos cruciais de "A condição pós-moderna" - tomada de Ludwig Wittgenstein. No terceiro capítulo desta obra, os jogos de linguagem não são mais que o método escolhido para melhor discernir a pragmática típica de cada tipo de saber, enunciado ou princípio de legitimação. Cada um funcionaria de acordo com regras próprias que permitem ou impedem uma série de lances possíveis no desenvolvimento do jogo.

Quantas espécies de frases existem? Afirmação, pergunta e comando, talvez? - Há inúmeras de tais espécies diferentes de emprego daquilo que chamamos de "signo", "palavras", "frases". E essa pluralidade não é nada fixo, um dado para sempre; mas novos tipos de linguagem, novos jogos de linguagem, como poderíamos dizer, nascem e outros envelhecem e são esquecidos. (Uma imagem aproximada disto pode nos dar as modificações da matemática.)

O termo "jogo de linguagem" deve aqui salientar que o falar da linguagem é uma parte de uma atividade ou de uma forma de vida. outros:

Imagine a multiplicidade dos jogos de linguagem por meio destes exemplos e

Comandar, e agir segundo comandos -

Descrever um objeto conforme a aparência ou conforme medidas -

Produzir um objeto segundo uma descrição (desenho) -

Relatar um acontecimento -

Expor uma hipótese e prová-la -

Apresentar os resultados de um experimento por meio de tabelas e diagramas -

Inventar uma história; ler -
Representar teatro -
Cantar uma cantiga de roda -
Resolver enigmas -
Fazer uma anedota; contar -

${ }^{30}$ Não é intenção de Lyotard afirmar que é a primeira vez que o saber muda de estatuto, o mais razoável seria reconhecer que este está sempre mudando ou que mudou em diversas vezes na história. Interessa realmente ao autor, precisar melhor como é este novo estatuto decorrente das recentes injunções históricas. 
Resolver um exemplo de cálculo aplicado -

Traduzir de uma língua para outra -

Pedir, agradecer, maldizer, saudar, orar -

- É interessante comparar a multiplicidade das ferramentas da linguagem e seus modos de emprego, a multiplicidade das espécies de palavras e frases com aquilo que os lógicos disseram sobre a estrutura da linguagem (...).

(WITTGENSTEIN, 1999, p.35, 36)

Desta citação, notamos que não há uma definição para tal noção, mas uma tentativa de ilustração ou elucidação, sucedida por uma série de exemplos. A provável recusa de uma tentativa de definição residiria na hipótese de que não há uma afinidade única ou característica comum a cada um destes jogos. O autor enfatiza mesmo que a simples ideia de jogo é um termo em que qualquer tentativa de significação deixaria de fora algum jogo específico, que não se enquadraria em tal tentativa.

Três observações precisam ser feitas a respeito dos jogos de linguagem. A primeira é que suas regras não possuem sua legitimação nelas mesmas, mas constituem objeto de um contrato explícito ou não entre os jogadores (o que não quer dizer todavia que estes as inventem). A segunda é que na ausência de regras não existe jogo, que uma modificação, por mínima que seja de uma regra, modifica a natureza do jogo, e que um "lance" ou um enunciado que não satisfaça as regras, não pertence ao jogo definido por elas. A terceira observação acaba de ser inferida: todo enunciado deve ser considerado como um "lance" feito num jogo.

(LYOTARD, 2011, p. 17)

Assim, interessa a Lyotard notar que há diferentes regimes de enunciação, cada qual com sua própria regulação, sem que seja possível tomá-los e interpretá-los todos pela mesma e única via, como se houvesse um possível ‘metajogo'. Até mesmo a ideia de que todos jogam para ganhar deve ser tomada de forma relativa e não absoluta, uma vez que nem todo jogo implica em derrotar um oponente.

O recurso à noção de jogos de linguagem nos permite afirmar que, se não há uma única definição de jogo, não haverá também uma metalíngua, um regime de legitimação que abarque todos os outros, havendo sempre diferentes regimes de legitimação dos enunciados.

Destacamos a seguir quatro pontos enumerados por Lyotard para caracterizar o saber científico (2011, p.46, ss): 1- Entre os diversos jogos de linguagem possíveis, o saber científico isola um deles, o denotativo. Outros como a interrogação ou a prescrição só tem valor como suporte da argumentação dialética - lembremo-nos do silogismo aristotélico - de modo que um enunciado sobre um referente possa ter seu valor de verdade verificado. 2- O 
saber científico não é imediatamente partilhado socialmente, como o é o saber narrativo. Assim, nas sociedades modernas o saber científico dá origem a profissões e a instituições onde se agrupam este tipo específico de jogos de linguagem. 3- A validade do enunciado assim como da competência daquele que o enuncia é submetida ao assentimento de uma coletividade dos que estão em igualdade de competência. Assim, entendemos que o enunciado científico está sempre submetido a ter sua validade aceita por uma comunidade de experts em determinada matéria na qual são mutuamente reconhecidos em sua competência. Assim o saber acumulado anteriormente em seus enunciados é referência para a enunciação de novos, ou seja um novo deve se colocar de modo a refutar os anteriores. 4- O jogo da ciência exige memória e projeto. O remetente atual de um enunciado científico deve conhecer os enunciados anteriores de maneira que quando profere um novo, saiba de que maneira este se diferencie dos demais.

Passo a fazer algumas considerações para caracterizar o saber narrativo, de maneira a distingui-lo de modo suficiente do saber científico. Ao contrário deste, o narrativo não tem a mesma necessidade de isolar o enunciado denotativo, que poderá ser combinado com outros (2011, p. 36 e ss). Se não é feito uso somente deste tipo de enunciado, deslocamos a necessidade de avaliar o critério único de verdade para objetivos mais amplos que se referem a uma diversidade maior de enunciados. O saber narrativo, e também aquele que os propaga, têm seus enunciados avaliados por critérios como eficiência, justiça, felicidade, beleza, etc. Não se pode deixar nos escapar a afinidade encontrada entre determinados saberes transmitidos pela narração com os costumes adotados por determinada sociedade. Uma boa performance nestes saberes (saber-fazer, saber-viver, saber-escutar, etc.) é considerada boa no interior do consenso que formou os critérios pertinentes para assim os considerar. A cultura de um povo irá, baseado nestes critérios, distinguir aquele que é portador destes saberes daquele que não é (como, por exemplo, a criança e os estrangeiros).

As histórias populares que dão sustentação a estas culturas podem ser chamadas de ‘formações' positivas ou negativas. Tais histórias, lendas ou contos representam modelos positivos ou negativos de integrações às instituições estabelecidas daquele povo. Nestas narrativas se conta a sorte do herói que será feliz ou infeliz em sua aventura, para nelas se fixar o modelo que rege os vínculos de um povo com sua cultura e suas normas de convivência e de sociabilidade.

Feitas estas breves considerações sobre as distintas pragmáticas do saber científico e do saber narrativo, passemos a examinar uma possibilidade outra: o momento em que um 
saber, que se pretende científico, faz uso de um relato, ou seja, de um saber narrativo. Não por acaso, Lyotard nota bem que todo jogo de linguagem apresenta o problema de sua própria legitimidade (2011, p.52). Qual melhor exemplo que os diálogos de Platão? Ali a pragmática da ciência é tematizada ou tomada como pressuposto. No debate proposto, não se pode perder de vista "a argumentação unicamente com fins de consenso (homologia), a unicidade do referente como garantia de possibilidade de chegar a um acordo, a paridade dos participantes, e mesmo o reconhecimento indireto de que se trata de um jogo e não de um destino (...)"

Deste modo, pode se falar que o discurso platônico se coloca como científico de maneira não científica. É bem conhecido como o problema da autoridade sociopolítica, tratada nos livros VI e VII da República, faz uso de um relato, a alegoria da caverna. Lyotard sugere que isso se justificaria pela alegação de que os homens resistem em reconhecer o saber e preferem os relatos.

A questão sobre os usos dos relatos como recurso de legitimação do saber científico pode ser melhor evidenciada se notarmos que estes passam a ser consolidados na emergência da modernidade. $\mathrm{O}$ advento da ciência moderna é contemporâneo à hegemonia de uma nova classe que precisa, de modo análogo, ter sua autoridade reconhecida. Assim, a ciência moderna se afirma por uma nova atitude científica de maneira que, ao interrogar as provas ou as condições de verificação daquilo que é verdadeiro, recusa uma autoridade transcendente, propondo que as regras do jogo da ciência sejam imanentes ao próprio jogo. A maneira de interrogar a legitimidade sociopolítica se dá de maneira bastante parecida. O povo que quer se legitimar como nova autoridade coloca no consenso e na deliberação o seu sinal de legitimidade e não em uma autoridade que se legitime de forma transcendental.

Portanto, o povo debate consigo mesmo sobre quais são as leis mais justas a ponto de reuni-las, acumulá-las e aperfeiçoá-las tanto quanto julgarem preciso. Os cientistas propõem leis que podem ser superadas ou melhoradas por novas leis, mais verdadeiras ou mais adequadas aos seus novos questionamentos. Em ambos os casos, estes acúmulos pressupõem a ideia de progresso e de que novos paradigmas possam ser alcançados por tais aperfeiçoamentos.

Temos então, nesta maneira de legitimação a partir da reintrodução do relato como validade do saber, a emergência de dois tipos de heróis: o do conhecimento e o da liberdade. Quanto ao herói do conhecimento, suas leis científicas, que devem ser aceitas por sua validade ou veracidade, nada são além de enunciados denotativos, ao passo que o herói da liberdade, ao propor algo que deva ser considerado justo, propõe enunciados prescritivos, dos 
quais não se pode exigir veracidade ou validade. Além disto podemos colocar a questão da avaliação da competência daquele que profere o enunciado. A competência daquele que diz que "algo é tal como eu digo ser" não é da mesma natureza do que diz "isto deve ser feito tal como eu digo que deve ser feito". 31

Neste exato ponto, lembremo-nos da ideia, já abordada, de que a educação legou à Filosofia a cara tarefa da emancipação. A instituição escolar, lugar de propagação dos saberes científicos, tem sua legitimidade posta nos ideais de liberdade e emancipação. Assim o saber não se legitima a si mesmo, mas busca referência nestes ideais e promove a esta função heroica instituições como a escola e a universidade.

Como foram então que tais ideais, chamados por Lyotard de metarrelatos, perderam sua força de legitimação? Pois cumpre notar que o grande relato - com seu poder de unificação, seja qual for o tipo de relato - não encontra a mesma credibilidade de antes. Examinemos a questão tal como propõe Lyotard.

O declínio desses relatos é habitualmente associado ao crescente desenvolvimento das técnicas e tecnologias do pós Segunda Guerra Mundial e ao capitalismo liberal avançado, uma vez desprendido da resguarda keynesiana. Ainda que não se possa negar tal associação causal, o autor sugere que seja possível encontrar nos próprios princípios de legitimação da ciência, elementos que levaram à sua deslegitimação. Dito de modo mais resumido possível: o saber científico que propõe um discurso denotativo sobre um referente qualquer possui também um dispositivo especulativo que nutre uma suspeita sobre aquilo que acredita saber, desta forma, leva a um ceticismo em relação ao conhecimento positivo, uma vez que a própria linguagem de legitimação precisa legitimar a si mesma. Assim, a exigência científica de verdade deve aplicar a si mesma esta própria exigência.

Portanto, o processo de deslegitimação tem como motor o próprio processo de legitimação (2011, p. 69-71). Onde a ciência, a pesquisa e o ensino buscam encontrar seu princípio de legitimação neste novo cenário? Naquilo que Lyotard chama de desempenho. Os saberes não são mais avaliados pelo seu papel formativo, que exercem frente àquele que aprende, mas por uma pragmática ainda mais utilitária. Passa-se a se perguntar sobre o que é proposto como matéria de conhecimento ou aprendizado: “isto é vendável?”, “isto é eficaz?”.

${ }^{31}$ Acerca desta discussão em "A condição pós-moderna", pode-se dizer que ela adquire um outro tom em "Le Differend". Nesta obra, a discussão passa a ser sobre a ligação entre as frases, o que leva Lyotard a considerar que não é possível que uma frase prescritiva seja deduzida de uma frase denotativa ou cognitiva (da qual podemos julgar sua validade ou veracidade). Da frase "Existe uma grande desigualdade de riquezas neste país", a frase "devemos repartir as riquezas" não terá mais validade do que a frase "Os ricos devem se tornar ainda mais ricos pois fizeram por merecer." 
O que deve ser aprendido e ensinado serão competências que sejam operacionais. Por isso o saber parece cada vez mais indistinto de um "saber-fazer". O conhecimento a ser aprendido se irmana à técnica, que se orienta pela otimização das performances, entendidas como a relação entre "aumento do output (informações ou modificações obtidas) e diminuição do input (energia despendida) para obtê-las (2011, p. 80)". Os jogos aqui passam a operar por outro tipo de determinação, que deixa de ser o que é verdadeiro ou justo, mas o que é eficiente. Um lance é considerado bom ou bem sucedido quando despende pouco em relação ao que rende. Tais considerações são feitas por Lyotard para a legitimação do ensino ou da pesquisa, através do desempenho, tendo em vista principalmente a produção de conhecimento no interior da universidade. Vale ressaltar que a discussão do autor não aponta de forma mais específica e detida sobre a transmissão destes saberes ou da relação de ensino e aprendizagem na educação básica ou no Ensino Médio, etapa do ensino escolar que mais interessa para este trabalho.

Temos então que o princípio orientador da eficácia, que a técnica traz consigo, encerra uma relação com o investimento ou financiamento e o poder. Sabemos desde a primeira revolução industrial que não se pode conceber técnica sem riqueza, nem riqueza sem técnica. Assim, no jogo científico o papel do dinheiro se mostra decisivo: a otimização das performances do corpo humano que melhor administram aquilo que pretendem comprovar exige financiamento adequado. O critério de definição sobre o que deve receber financiamentos de maneira prioritária seguirá a orientação da eficácia da relação entre output e input. Daí, a seguinte questão colocada por Lyotard: o ímpeto de melhoria de performance resulta de um desejo de conhecimento ou de enriquecimento?

Assim são colocados os lugares de poder no jogo científico, o que leva a Lyotard a investigar o discurso do poder e suas possibilidades de legitimação. Parece já estar suficientemente claro que o princípio da eficácia orienta mais a pesquisa científica do que o faria a busca da verdade. O Estado ou a empresa não se orientam mais pelo relato de legitimação iluminista ou humanista (2011, p. 83). Se há maior investimento em cientistas e técnicos não se trata de uma maior predileção por um saber verdadeiro que poderia concorrer para a emancipação dos homens, mas para aumento de poder.

No entanto, ainda encontramos na tradição uma oposição entre força e direito. Ora, entre os diferentes jogos de linguagem possíveis, Lyotard percebe que a velha pertinência das oposições justo/injusto, verdadeiro/falso tem agora que conviver com o critério do eficiente/ineficiente. De acordo com o parecer do autor, a força só parece se relacionar com este último jogo de linguagem (2011, p. 83), o que pode nos levar à seguinte questão: como a 
força entra em um jogo de linguagem? Creio que não haja no escrito de Lyotard nada que nos permita dizer que os jogos de linguagem devam ser jogados entre pessoas em posições de perfeita igualdade, de modo que é necessário que entre a ideia de força e a ideia de terror haja uma diferenciação. Se um participante do jogo formula a proposição "Diga ou faça isto, senão não falará mais" elimina-se o parceiro e desfaz-se o vínculo social.

Assim, se na otimização do desempenho, obtém-se um melhor controle sobre a administração das provas necessárias para um experimento qualquer, sobre o contexto ou a "realidade" da qual é entendido como referente daquilo que se diz, a ampliação das possibilidades técnicas permite um maior domínio sobre a natureza. A consequência deste poder sobre a realidade implica também em ter maiores chances de estar certo ou até mesmo de ser justo. Assim a legitimação pelo poder toma a seguinte forma: o lance ideal de um jogo deve gerar a otimização do desempenho, este depende de recursos que ampliem as possibilidades técnicas que aumentarão as chances não só de ser mais eficiente, mas de encontrar maior certeza nas suas proposições. Assim podemos compreender melhor as justificativas de escolhas de maior aporte financeiro neste ou naquele centro de pesquisas.

Parece ser precisamente nesta legitimação pelo desempenho que encontramos os fundamentos do idioma que o mundo ensina aos jovens, que são jogados na instituição escolar. Se tais jovens falam uma língua permeada pela velocidade, pela competitividade, pelo sucesso ou pela realização (1993a, p. 125), tais exigências ou promessas deste idioma demonstram guardar grande afinidade com a legitimação pelo desempenho. Para Lyotard, “o mundo fala sob a regra da troca econômica, generalizada sob todos os aspectos da vida, incluindo as afeições e os prazeres". A regra da troca econômica, que tende a se generalizar, parece servir de suporte para que a legitimação pelo desempenho torne a ser cada vez mais a forma de legitimação hegemônica na contemporaneidade. Em Le Differend, o argumento destoa muito pouco deste. Nesta obra, Lyotard passa a considerar o Capital não exatamente como um gênero de discurso, mas como dando hegemonia política ao gênero de discurso econômico, que tem como principal tarefa ou objetivo ${ }^{32}$ ganhar tempo. Tempo que é medido

\footnotetext{
${ }^{32}$ Aqui o termo francês utilizado em Le Differend é enjeu, de difícil tradução. Na tradução para a língua inglesa temos o termo stake, o qual também não facilita nossa tentativa de tradução. Tal termo não pode ser confundida com a expressão en jeu, cuja tradução literal seria 'o que está em jogo', expressão que aparece igualmente com frequência na obra. Na tradução de Marina Appenzeler para o texto "Um parceiro estranho" (1996, p.123) encontramos a opção pelo termo 'desafio', que não considero o melhor termo para ser usado neste contexto ou neste momento.
} 
pelo lucro calculado em quantias de dinheiro (1988, p. 138, 139; LD 191) ${ }^{33}$. Assim não se trata apenas de otimizar uma performance a partir do princípio de obter ou render mais, frente ao que foi despendido, mas que as performances possam vir a economizar ou estocar tempo.

A partir destas considerações feitas sobre esta mudança do estatuto do saber que põe em descrédito a força de legitimação que antes possuíam as metanarrativas, coloco a seguinte questão: Como podemos pensar um ideal de formação que possa ser atribuído não somente à instituição escolar, mas também a disciplina de Filosofia que passa a integrá-la?

Ao destacarmos a tarefa da emancipação como objetivo maior da formação, foi possível aproximá-la da metanarrativa iluminista. Deste modo o problema parece estar fixado: a escola, na forma que a conhecemos, tem a sua razão maior de ser na realização daqueles objetivos colocados pelo Iluminismo, ou seja, sua função se deve ao poder de legitimação que tal metarrelato chegou a ter, pelo menos em determinado momento.

\begin{abstract}
O declínio dos ideais modernos acrescenta à persistência da instituição escolar republicana, que com eles se sustentava, esse efeito de atirar para o curso filosófico espíritos que lá não entram. Sua resistência parece invencível, precisamente porque não tem por onde se lhe pegue. Falam o idioma que lhes ensinou e ensina o 'mundo', e o mundo fala velocidade, gozo, narcisismo, competitividade, sucesso, realização. (...) Este idioma é completamente diferente do idioma do curso filosófico, é-lhe incomensurável. (...) $\mathrm{O}$ aluno e o professor são vítimas um do outro $^{34}$. (1993a, p. 125)
\end{abstract}

Apesar do declínio destes ideais, a escola que neles sempre se amparou, ainda persiste. A exigência por emancipação, a qual tomava como tarefa, passa a se situar em um território que apresenta sinais de algo parecido com um limbo. Esta exigência pode ser abandonada repentinamente ou trocada por algo melhor? Tal tarefa pode ser retomada, mesmo sem o amparo daqueles ideais? Ou ela será colocada de modo a ser reexaminada e revista a partir de outras perspectivas ou intentos?

Sendo este o diagnóstico que foi possível configurar, a relação entra a formação e o ensino de Filosofia torna-se um problema a ser discutido. Seja a partir do enfoque pelo qual as três perguntas feitas no parágrafo anterior se encaminham, seja de outra forma. A seguir,

\footnotetext{
${ }^{33}$ Uma vez que a obra Le Differend não foi traduzida para a língua portuguesa, toda indicação feita desta trará não somente a paginação da edição inglesa, mas também o seu parágrafo, sucedido pela sigla LD, para que possa ser conferida na versão original francesa ou em outras traduções.

${ }^{34}$ Mais adiante através do recurso à noção de 'diferendo' do qual Lyotard faz uso a partir da obra homônima, iremos precisa melhor o que é uma vítima em um diferendo e de que forma e em que medida neste contexto, aluno e professor são vítimas um do outro.
} 
pretendo discutir sobre possíveis modos de pensar esta relação a partir de três 'casos' que considero exemplares para tal discussão. Estes 'casos' são provenientes de estudos feitos acerca da discussão sobre a necessidade ou importância da inclusão da disciplina de Filosofia no currículo do Ensino Médio brasileiro. 


\section{Sobre as conexões entre ensino de Filosofia e ideal de formação:}

Acerca do debate sobre o ensino de Filosofia, muitas podem ser as formas de discutir a questão. A perspectiva escolhida neste trabalho é a de explorar as possíveis relações entre o ideal de formação e o ensino da disciplina de Filosofia nos currículos do Ensino Médio.

Quando o tema da formação aparece nos artigos e obras que dos anos noventa aos dias atuais se dedicaram a discutir - e na maioria das vezes militar a seu favor - a importância da inclusão da disciplina no currículo do Ensino Médio, encontramos o tema da formação com uma recorrência que não pode ser desprezada. No entanto, o modo como a formação deve ser pensada, ou levada em conta, nas reflexões sobre como se deve dar o ensino de Filosofia não alcança consenso. Se não há uma evidente querela sobre a discussão, há ao menos pontos de vista suficientemente dissonantes sobre a referida relação.

Antes de analisar cada um destes pontos de vista, proponho um breve exame acerca de alguns apontamentos encontrados em discursos que militavam para o retorno efetivo da Filosofia na grade curricular do Ensino Médio brasileiro ou que visavam garantir que este retorno não se limitasse ao plano formal de uma lei. Tais apontamentos serão analisados no sentido de examinar até que ponto podem indicar expectativas de um sentido formativo no ensino de Filosofia que estariam associadas aos anseios de redemocratização do país.

Tal exame deve nos servir de introdução para um debate sobre a forma como foram tratados os intentos formativos - assim como sua validade - do ensino da Filosofia no Ensino Médio brasileiro, em algum textos que, além de militar em sua causa, discutiram sua importância ou emergência.

Assim, mal o Brasil dava seus primeiros passos rumo à redemocratização, após o período da ditadura civil-militar, já era notável como diversos atores sociais concorreram para a reativação e defesa dos direitos sociais, que ainda viriam a ser garantidos pela constituinte que acarretaria na Constituição Federal de 1988, em especial no que tange à educação. No caso da militância para a presença da Filosofia nas escolas não foi diferente. Há muito tempo alijada $^{35}$ do currículo escolar, educadores e professores de Filosofia se valeram das primeiras

\footnotetext{
35 Em primeiro lugar não houve exclusão formal da disciplina pelo regime militar de modo que era expressamente proibido a sua participação nas grades curriculares, mas uma série de medidas, inclusive em governos anteriores, que acarretaram uma presença rara e incipiente da Filosofia nas escolas, uma vez que o caráter da disciplina era facultativo. Para uma historicização mais precisa do período e das diversas idas e vindas
} 
frestas da abertura democrática para encampar a luta por uma presença efetiva da disciplina no Ensino Médio, ainda chamado de Segundo Grau, naquele momento. Dado tal contexto, examinaremos nos textos e documentos a expectativa que recai sobre a contribuição que a Filosofia, inserida no currículo escolar, teria para a tarefa de reconstrução da cidadania. Desta forma, é possível inferirmos que a expectativa sobre o papel que a filosofia teria, a partir de sua inserção no currículo escolar, seria o de contribuir significativamente para a reconstrução da cidadania.

Sugiro que voltemos nossos olhares para alguns documentos e discursos destes períodos, no sentido de tentarmos encontrar afinidades entre a expectativa de um sentido formativo da Filosofia e o esforço pela reconstrução da cidadania e vida civil em uma sociedade outrora - mas também ainda naquele momento - regida pelo arbítrio despótico ${ }^{36}$. Tal contexto não pode ser elidido nem cair no esquecimento. A luta pelo retorno da Filosofia e a forma que assume na grade curricular, dependerá em alguma medida do estatuto que foi conquistado através de discursos tais como os que traremos aqui.

Farei uso de documentos propostos pela Sociedade de Estudos e Atividades Filosóficos (SEAF) publicados em 1986, em que chamaremos atenção sobre tal expectativa que recai sobre a Filosofia. A preocupação destes documentos cai muitas vezes no preparo para a cidadania que a educação formal deve propiciar, assim como também é nítida a preocupação com a desejável visão crítica que deveria ser despertada no aluno. Cidadania e criticidade $^{37}$ parecem ser os dois pontos fortes em que se apoiam um certo ímpeto formativo dos discursos deste período. Claro que, por cidadania, naquele momento se entendia, de maneira muito mais inequívoca do que hoje, a participação na vida política, anseio de uma população que se viu excluída dela por cerca de duas décadas. Tal participação deveria passar não somente pela escolha popular dos representantes, mas também pela participação na discussão dos principais problemas e questões do país.

\footnotetext{
da filosofia nas escolas, conferir ALVES, Dalton José. A filosofia no ensino médio: ambiguidades e contradições na LDB. São Paulo. Editora Autores Associados, 2002.

${ }^{36}$ Não quero sugerir que tal proposta encerre ou resuma as finalidades colocadas ao reingresso da filosofia na grade curricular. A intenção é somente avaliar uma perspectiva possível que considero poder ser estratégica para os objetivos deste estudo e para a discussão sobre as potencialidades da filosofia como disciplina escolar.

37 Já naquele momento Nielsen Neto (1986, p. 14 e 15), alertava sobre o desgaste da palavra crítica, e de um indesejável e frequente senso comum que dominava o uso do termo.
} 
Eu acho que a filosofia tem que ser uma reflexão sobre os problemas contemporâneos e no espaço cultural em que vivemos. Vivemos no Brasil, então temos que formar uma consciência crítica de nosso processo cultural, político, econômico e social. Não basta que saibamos repetir os grandes mestres da filosofia nem que conheçamos os princípios. É claro que temos de recorrer ao pensamento clássico, repensar os grandes autores, mas isto é insuficiente para que sejamos sujeitos do processo histórico. O processo educacional, no seu todo, deve ser crítico; a filosofia tem uma responsabilidade especial neste sentido, porque ela sempre foi crítica e quando não foi crítica se perdeu. (PEGORARO, 1986, p. 11)

O discurso aqui apresentado poderia muito bem ser proposto ou endossado em um momento como o atual, sem que sua exposição formal indicasse de maneira inequívoca estar inserido em um contexto de redemocratização e abertura política. Tais princípios ainda são válidos e podem ser defendidos para a Filosofia na escola hoje. Ainda assim, é necessário enfatizar o modo como foi valorizada a formação de uma consciência crítica tida como necessária para aquele momento.

Podemos apontar tal modo como bastante marcado por um espírito predominante do que se esperava do papel da Filosofia na vida escolar. Somente sua força crítica é o que poderia fazer de alguém sujeito do processo histórico, capaz de avaliar os diversos processos do contexto do país para dele tomar parte. Desta perspectiva, a Filosofia teria um papel que não pode ser entendido como desinteressado; ela não deveria se limitar aos problemas próprios de seus autores e temáticas, mas sim, partir do recurso a eles e de eventuais, talvez desejáveis, atualizações. Assim, a sugestão se dava no sentido de que o recurso à Filosofia ocorra sem que nossos olhos se desviem do momento presente.

Desta maneira, se o processo de engajamento para o retorno efetivo da Filosofia aos currículos escolares se encontra associado ou integrado a um movimento maior, que visa reabilitar os marcos para uma educação que seja o sustentáculo de uma democracia com ampla participação civil, o olhar que devemos ter para os discursos ali colocados deve dar especial atenção à recorrência de alguns temas ou abordagens.

É nesse contexto que nasce e toma forma o movimento pela retomada e revitalização do ensino de filosofia, e ele tende a ganhar, no setor das ciências humanas, uma dimensão emblemática do conjunto das críticas à política educacional, do governo e do sentido mais geral de nossas reivindicações. A oposição se firma nesta área particularmente contra a degradação do ensino acarretada pela reforma (apontando sobretudo para a desqualificação, intelectual e social, dos profissionais da educação que tiveram sua formação “encurtada"); contra 
o afastamento dos professores do trabalho de pesquisa, transformando-os em vulgarizadores de informações fragmentárias; e por fim, contra a desvalorização do saber e da formação moldados na tradição das humanidades, em primeiro lugar, da filosofia, que são mais aptos a introduzir os estudantes ao registro de um pensamento crítico e reflexivo (CARDOSO, 1986, p. 69-70)

Podemos perceber bem como Sérgio Cardoso coloca que a militância impetrada pela criação da Sociedade de Estudos e Atividades Filosóficos (SEAF) mirava contra as reformas que o regime planejava realizar, de maneira a cercear não somente o espaço e as potencialidades da Filosofia, mas também o núcleo humanístico como um todo, com notável prejuízo para a formação de um pensamento crítico e reflexivo por parte do aluno, que dificilmente seria realizada por disciplinas tais como Estudos Sociais ou OSPB, por serem entendidas como afinadas aos interesses do regime militar. Ainda que o ponto central, como o autor parece indicar, esteja antes em uma política de pauperização e enfraquecimento da função docente do que nas mudanças curriculares.

Deste discurso em tom mais combativo, que mobiliza os intentos da SEAF para o retorno efetivo da Filosofia, no fím da década de setenta, chega-se ao início da década seguinte em que o discurso oficial passa a absorver parte das reivindicações e a tratar da necessidade da Filosofia por um sentido que diverge, não completamente, mas em alguma medida, das propostas e interesses daqueles que buscavam o retorno efetivo da disciplina (CARDOSO, 1986, p. 72 e ss). Uma vez que o fracasso no sentido de especialização profissional que o Segundo Grau assumia era evidente, e aceito mesmo pelos órgãos oficiais, o discurso de uma "formação geral" passava a ter mais adeptos. Deste modo, o predomínio desta tendência foi entendida como portadora de um "consenso mínimo" que conciliaria dois polos divergentes. Um exemplo ilustrativo é a carta enviada pelo Departamento de Filosofia da USP em 1983 ao MEC:

(...) a Filosofia - diz se aí - se constitui como uma das formas de expressão cultural consagrada há milhares de anos, cujas marcas deixadas no ocidente são inegavelmente profundas. Privar os alunos do segundo grau do acesso a esta disciplina é arrebatar-lhes uma parte importante da sua própria história, é impedir que tenham acesso a uma esfera do saber que, ao lado dos demais, permitirá que elaborem, da melhor maneira possível sua visão crítica do mundo. Referência à cultura, história e crítica - traços fundamentais do Humanismo na sua forma clássica - completada, em seguida, pelo enunciado da sua dimensão emancipatória autonomia do pensamento face a toda a autoridade exterior - e cívica - apelo à liberdade no âmbito da lei e do direito (...) (apud. CARDOSO, 1986, p. 74, 75). 
Mas tal avanço não estava livre de perigos, como nota Cardoso, ao apontar que a Filosofia passa a ser defendida como bem cultural do qual todo cidadão deveria ter direito de se apropriar. Ainda que tal discurso não seja de todo divergente das propostas ou avaliações da SEAF, ele parecia estar propenso a ser tomado em um sentido mais conservador, tendo em vistas o modo como era encampado pelos órgãos oficiais. Assim, a formulação do argumento preocupa menos que a assimilação apressada, que poderia ser contrária ao que é específico do perfil da disciplina. O que o autor parece querer advertir naquele momento seria o perigo de que aquelas proposições fizessem com que a Filosofia se tornasse nada mais do que um saber positivo - não raro moralizante ou totalizador da experiência - desprovido de seu potencial de radicalidade e crítica.

Sendo este o contexto que propicia não somente a retomada da discussão sobre o ensino de Filosofia, como seu efetivo retorno no ano de 2008, examinemos a três diferentes perspectivas para discutir a relação entre ensino de Filosofia e ideal de formação, de acordo com o recorte aqui proposto.

A primeira se encontra em uma série de textos escritos por Franklin Leopoldo e Silva, ainda que nem todos versem sobre o ensino de Filosofia ou sobre sua inserção no currículo do Ensino Médio. Nestes textos, aponto o que chamarei de uma 'permanência' do ideal de formação ${ }^{38}$ nas suas propostas para o ensino de Filosofia. Ao longo do exame das propostas e análises contidas em seus textos, discutiremos como pode ser entendida esta permanência.

Nos textos que examinamos a seguir, encontramos espaço destacado para o ideal de formação, que parece permanecer nos desígnios da inserção curricular da Filosofia. De que maneira o autor recorre a esta noção? Inicialmente situando a de acordo com a expectativa de unidade, que nela estaria implícita, face a fragmentação da experiência e do mundo ou também da dispersão das ciências e saberes no currículo do Ensino Médio:

A fragmentação da experiência não é acidental nem deve ser tratada apenas psicologicamente. Os exercícios que visam levar o estudante à ordem do discurso filosófico possuem a finalidade de compreensão e ordenação reflexiva da

\footnotetext{
${ }^{38}$ Não teremos a ingenuidade de acreditar que em cada um dos autores que discutem o ensino de filosofia e o tema da formação, encontremos esta ideia tomada da mesma forma ou de maneira inequívoca. O uso que cada autor faz do termo possui particularidades que faz com que o debate nos impeça de tomar partido inequívoco de um ou outro lado, assim como é preciso tomar cuidado para não elidir as especificidades de preocupações que cada autor tem e que se distinguem umas das outras. Ainda assim, é possível aproximar estes usos, encontrar afinidades, dissonâncias e tensões que elas carregam consigo, seja elas tomadas isoladamente, seja em confronto uma com as outras.
} 
experiência. Este tipo de inteligibilidade distingue-se da racionalidade instrumental - ambiência mais natural do sujeito no mundo moderno —- primeiramente por levar a uma tomada de consciência da própria fragmentação. A objetivação da experiência é objetivação da fragmentação, na medida em que refletir sobre as relações entre sujeito e cultura é antes de mais nada pôr-se em condições de reconhecer a fragmentação do sujeito num mundo cultural fragmentado. Somente desta maneira é que poderão ser criadas condições para pensar criticamente a própria fragmentação. Para que isto ocorra é preciso que a fragmentação seja reconhecida como determinação histórica: isto já é parte da reflexão propriamente filosófica, pois é uma abordagem filosófica da História. Aqui os objetivos filosóficos e os propósitos "pedagógicos" entram em consonância, pois a formação só pode ser entendida a partir de uma postura crítica em face da fragmentação. O Eu como instância interior, a subjetividade epistemológica, a consciência representante, a cidadania como dimensão política do sujeito, as relações entre individualidade e democracia, a massificação, a dominação anônima, a reificação da intersubjetividade etc. são temas que de diversas maneiras se ligam à fragmentação da experiência no mundo contemporâneo. Por isto esta fragmentação não pode ser tratada apenas na dimensão do vivido imediato. Este é muito mais a instância em que repercutem injunções históricas mais amplas. A ausência de reflexão sobre tais injunções impedirá que a abordagem da experiência fragmentária seja ao mesmo tempo um caminho para superar a alienação. É neste sentido que o próprio espaço da aula adquire função formadora: quando a reflexão compromete o sujeito na busca sistemática dos significados das aparências e numa arqueologia da sua situação individual, social, histórica e política. O próprio enunciado destes vários aspectos já sugere que a abordagem crítica da experiência só terá um sentido filosófico se for ao mesmo tempo uma articulação destas várias instâncias situacionais. E a partir desta articulação que se constituirá a projeção transcendente enquanto singularidade humana: o sujeito se dará conta de que nenhuma das condições particulares sob as quais se exerce a sua subjetividade na diversidade de conjunturas do mundo que o circunda satisfaz o requisito global de humanidade, e que somente através da rearticulação crítica e vivida de todas essas dimensões é que ele poderá verdadeiramente encontrar-se e ao outro. (LEOPOLDO E SILVA, 1993, p. 803)

Portanto, a função maior do ensino de Filosofia deverá conter uma intenção formativa que situe a fragmentação da cultura e da experiência como parte de determinações históricas que nos afetam na contemporaneidade. A reflexão contida no trabalho a ser feito a partir de temas como a cidadania, a massificação ou a reificação são ocasiões para que seja possível estabelecer uma posição crítica diante desta fragmentação.

Se esta reflexão pode ser realizada nos exercícios que visam constituir com o estudante uma ordem no discurso filosófico que permita dar algum tipo de inteligibilidade e ordenação à fragmentação da experiência moderna, encontramos aí um intento formativo que estabelece um caminho que se propõe superar a alienação. Assim, para o autor, a fragmentação não pode ser entendida como algo banal ou casual, mas como consequência de uma série de injunções históricas que podem ser pesquisadas e compreendidas para que esta superação seja possível. 
É importante registrar que não podemos esperar da Filosofia um instrumento aglutinador desta fragmentação, a ponto de dar-lhe um sentido unívoco e reorientá-la para uma nova unidade. O mesmo pode se dizer da dispersão dos saberes no currículo escolar. Pois, a Filosofia também é uma dimensão da cultura e não escapa de ser afetada por esta mesma fragmentação, aponta bem o autor. Ao mesmo tempo, ainda que afetada por esta, o potencial interrogante e reflexivo da Filosofia possibilita colocar a fragmentação como objeto de análise e investigação. Não com o objetivo de refreá-la ou revertê-la. Deste modo, se a Filosofia e seu ensino não podem reverter as determinações históricas da cultura contemporânea, podemos entender que sua função seja a de:

(...) impedir que tais determinações sejam aceitas na aparente naturalidade com que se apresentam na experiência imediata; é questionar o valor dessas determinações, confrontando-as, por exemplo, com os ideais originários do humanismo moderno e principalmente com a necessidade de preservação da autonomia que deve fundar o curso da experiência humana.

(id., ibid., p. 804)

Assim, ainda encontramos como tarefa da formação a necessidade de preservar como princípio orientador a autonomia da experiência humana, tal como elaborada pelo Humanismo moderno, o que pode ser colocado como algo bastante próximo do ímpeto pela emancipação, traço maior do ideal de formação, como reforçado nos capítulos anteriores.

Isto não significa que a Filosofia deva ceder à tentação de se colocar como metalinguagem da educação, articulando todos os outros saberes tal como fosse uma metodologia abstrata, pronta a incorporar as especificidades das áreas do saber em sua potência unificadora ou generalista.

A força da Filosofia não estaria aí, mas na sua força interrogante, que a impede de estabelecer um vínculo meramente instrumental com o exercício do poder. O autor parece indicar que ao assumir esta característica como sua principal força, a Filosofia passa a nutrir uma relação tensa com a ideia de interesse:

(...) em nome da formação do homem e do cidadão, promove-se na verdade a disseminação de dogmas sob o pretexto da positividade do saber filosófico. Na raiz deste depauperamento da Filosofia estaria sempre o interesse, seja ele individual, corporativo ou do Estado. E a presença do interesse que distorce fundamentalmente a atividade filosófica, mesmo que tal interesse coincidisse com necessidades 
históricas ou com a preservação de crenças necessárias à manutenção da sociedade. (1993, p.800)

Desta maneira, não se espera que o filósofo esteja a margem do tempo ou se escuse das exigências que a ele parecem postas - revertendo em certa medida o postulado de Schiller mas sim que jamais se exima da singularidade criadora e questionadora, o que nunca estará em completo acordo com as necessidades do Estado.

Portanto, a Filosofia que integra os currículos escolares não pode se colocar como metalinguagem organizadora dos outros saberes presentes no currículo nem como interesse do Estado, muito menos como sistema filosófico acabado à maneira de um saber positivo que se coloque como 'a Filosofia', em detrimento das filosofias em sua diversidade de abordagens e gêneros discursivos ou estilísticos.

Se temos de convir com Schopenhauer que é desonesto ensinar uma filosofia como sendo a Filosofia, por outro lado o recorte que obrigatoriamente se opera na história e nas áreas temáticas não pode propiciar a perda do vigor da Filosofia como força interrogante, pois é isto que se trata principalmente de transmitir. (id, ibid, p. 802)

Tratar a Filosofia das formas acima citadas acarretaria em retirar dela seu principal vigor, que é a força interrogante que perdura por toda a sua trajetória na História. Assimilar o estilo interrogativo, que é distinto de adquirir um saber-fazer, é algo que só pode se dar de forma concomitante ao aprendizado dos conteúdos presentes em cada tradição ou obra filosófica, e que não pode ser separado do caráter formador da Filosofia.

\begin{abstract}
A inserção curricular da Filosofia se distingue da das outras disciplinas na medida em que pretende algo mais que o processamento da informação e o treinamento do raciocínio. Nas condições atuais, o caráter formador da Filosofia só pode ser pensado numa relação de tensão com a informação e com o treinamento, que esta tensão se manifeste no currículo escolar é algo que deve ser inevitavelmente assumido, já que é esta tensão que abre o espaço para a manifestação da característica formadora da Filosofia. (1993, p.804)
\end{abstract}

É neste sentido que o autor discutirá a formação a partir de uma distinção em relação a noção de treinamento. Para Leopoldo e Silva (1992, p. 157 e ss.) existem dois percursos distintos de aprendizagem. Um diz respeito às informações presentes no conteúdo curricular, 
enquanto o outro se refere aos requisitos e procedimentos cognitivos necessários a cada disciplina. A etapa do Ensino Médio seria o momento certo e adequado para o aluno tomar consciência dos efeitos da aprendizagem que ocorrem ao tomar contato com os conteúdos escolares, no sentido de se perceber quais requisitos passa a possuir e a fazer uso, assim como passa a entender os distintos processos cognitivos os quais mobiliza para diferentes tarefas e estudos no cotidiano escolar. Esta tomada de consciência seria concomitante à etapa da vida do adolescente em que vai se formando de modo cada vez mais sólido as bases de sua personalidade, assim como o seu pensar e agir sobre o mundo e sobre os diversos grupos sociais do qual faz parte.

Talvez seja possível notar que o que acontece, de maneira assaz frequente, é somente o prolongamento das regras básicas de aprendizagem da etapa anterior de ensino, na qual o aluno aprende algo sem o perceber, entendendo que a aprendizagem se resume à dimensão da memorização de esquemas e padrões. Ainda que tal prolongamento não ocorra, é comum também encontrar uma insatisfação pedagógica por parte do aluno que, de modo confuso e com pouquíssima clareza, passa a adotar uma postura de resistência e inconformismo pedagógico, com os quais os professores e instituições educacionais não sabem muito bem como lidar.

Portanto, temos que ser cuidadosos ao falar de resistência ${ }^{39}$, pois esta pode surgir por diversas motivações. Por um lado, podemos entender um tipo de resistência associada à construção de referenciais próprios e processo de reconhecimento de si como pessoa, à qual todo jovem está propenso em um ambiente de socialização tal como é o escolar. Por outro lado, - e aqui estou a ir além do que é colocado pelo autor - a resistência também pode se dar quando uma proposta formativa de aprendizagem se apresenta a um conjunto de alunos que, não habituado e não preparado a dissociar aprendizagem de memorização, exige do professor somente a resposta rápida e a solução pronta de utilidade imediata e facilmente localizada e aplicável. Deste modo, creio que por quanto mais tempo se prolongue esse modo de aprendizagem típico do Ensino Fundamental - sobretudo de seu primeiro ciclo - maior será a apatia - ou até mesmo um certo tipo de resistência - resultante nos alunos.

Uma vez que é bastante difícil pensar em aprendizagem sem a presença de uma

\footnotetext{
${ }^{39}$ No capítulo seguinte, voltaremos à questão da resistência frente aos ideais formativos na educação ou no ensino de Filosofia.
} 
postura interrogante, podemos considerar que haja um potencial crítico na inquietação do aluno, que não aceita passivamente que o processo de aprendizagem seja somente algo imposto. Tal potencial não deve ser subestimado, assim como devemos evitar a sua domesticação - o que ocorre com maior frequência, visto a dificuldade comum de lidar com posturas questionadoras, em geral indesejáveis se comparadas à uma expectativa de dócil respeito à autoridade docente - uma vez que pode conduzir a uma reflexão mais aprofundada sobre momentos do conteúdo das aulas, assim como relacioná-los com seu pensar e agir.

Esta postura interrogante se torna ainda mais necessária de acordo com a concepção do autor para o ensino de Filosofia, uma vez que é na interrogação que encontramos a principal força da Filosofia, como já comentado. Ainda que esta postura, quando manifestada por parte dos alunos, possa até mesmo se dirigir contra as ações e objetivos de um professor, - não somente nas aulas de Filosofia - ela não pode ser interrompida ou cerceada por motivos quaisquer, mas em alguma medida deve ser orientada para algo próximo aos desígnios formativos que a disciplina ofereceria, assim como também aproximar os alunos do trabalho de assimilação do estilo interrogativo presente na diversidade de textos filosóficos, se formos pensar dentro da chave proposta por Leopoldo e Silva.

A quebra da passividade almejada no processo de aprendizagem do aluno de Ensino Médio, que deveria acarretar em maior dinamização deste processo, teria o sentido de que este assumisse o caráter de uma formação, distinto do reduzido alcance da ideia de treinamento. Esta seria entendida como mera aquisição de habilidades pela memorização e repetição de regras e padrões. Enquanto a formação, se não dispensa tal dimensão, exige que esta esteja adequadamente integrada ao reconhecimento categorial de tais padrões, assim como a compreensão da gênese e fundamentação destes.

Em outro artigo, Leopoldo e Silva (2002, p. 8) comenta quais têm sido as consequências do progressivo desaparecimento do ideal de formação. Temos assim uma situação em que o progresso resultou na compreensão de que a Filosofia deixou de ser necessária, e toda recorrência a ela não é mais do que um gosto fúnebre por um artefato cristalizado do qual não encontramos vínculos possíveis com nosso momento atual. Ponto de vista decorrente de um predomínio crescente de uma racionalidade instrumental.

Ainda assim - pelo menos quando tratamos do Ensino Superior - a Filosofia continua a ser valioso recurso, exigido por outros setores da universidade, para fundamentações de ordem epistemológicas e metodológicas, ou até mesmo para maior afinidade com as discussões sobre questões de ética ou outros domínios. Assim, mesmo que 
não haja registro de coisa muito semelhante no Ensino Médio, percebemos tendências em pensar a Filosofia mais e mais emaranhada nas exigências de uma racionalidade técnica ou até mesmo utilitária ${ }^{40}$.

Leopoldo e Silva prefere nos indicar que enquanto o predomínio desta lógica não tiver se completado, ainda havendo algum espaço para o ideal de formação de nossos alunos, podemos com eles investigar o que diferencia o fato de seu sentido e de que há algo para além do imediatismo bruto dos fatos.

A caracterização de formação comentada no outro artigo visaria tal propósito: desaparecido tal ideal de nossa paisagem educativa, nada nos restaria para além de um treinamento destas habilidades que permitirão somente contemplar os fatos e artefatos culturais desfilando diante de nós desprovidos de suas fundamentações, regidos somente pela casualidade ou aleatoriedade de sua causa ou emergência. Lembremos que para Gerárd Lebrun $^{41}$ (1976, p. 152), o motivo maior de êxito do filósofo se dá justamente nos momentos em que ele obtém a expulsão do acaso como possibilidade de explicação. Ou seja, o trabalho a ser feito com a Filosofia no espaço escolar não poderia jamais perder de vista a busca pelo sentido que não está explícito nos fatos ou acontecimentos que nos acorrem. A recusa do acaso teria o seguinte objetivo: permitir que a força interrogativa da Filosofia ative a reflexão sobre o porquê dos acontecimentos.

Conforme afirmado anteriormente, o termo formação é usado nos textos educacionais, assim como nos textos aqui discutidos sobre ensino de Filosofia, de maneira a sugerir significados diversos, ainda que seu sentidos sejam próximos. Até mesmo nos textos de Leopoldo e Silva que aqui foram citados e debatidos, o termo formação apresenta, senão nítidas distinções, tons diferentes em seus usos.

No primeiro momento, notamos como a ideia de formação é requerida face a fragmentação notada no domínio do mundo cultural, assim como na experiência que temos com este. Assim, a formação passa a ser necessária para que seja alcançada alguma compressão ordenada desta situação de fragmentação, mesmo que sem a pretensão de revertê-

\footnotetext{
${ }^{40} \mathrm{O}$ que entendo como mais próximo a este fenômeno no ensino médio é o ganho crescente de espaço nos currículos de ensino médio técnico de disciplinas sobre ética. Tendência análoga é aquela que reconhece que a maior importância ou função das aulas de filosofia na educação básica seria o ensino de ética, ainda que muito provavelmente em uma perspectiva moralizante.

${ }^{41}$ Referência comum a textos de Favaretto e de Fabbrini, terá algumas de suas teses, que foram apropriadas para pensarmos o ensino de filosofia, discutidas adiante.
} 
$1 a^{42}$ ou superá-la. A formação é assim colocada como um objetivo que antagoniza frente ao predomínio de uma racionalidade instrumental que propicia ainda mais a situação de alienação e de reificação.

A fragmentação, com suas conseqüências, ocupa o lugar daquilo que deve ser combatido ou enfrentado na atividade que a formação pode exercer no ensino da Filosofia. Daí o recurso de confrontar tal experiência contemporânea com os objetivos do Humanismo moderno, que é orientado pelo princípio de busca da autonomia da ação humana. Um ensino de Filosofia que por aí se orienta, coloca em suspensão os valores das determinações do mundo fragmentado, para que voltemos nossos olhares ao que foi proposto, ainda que não alcançado, por aqueles ideais humanistas.

Para além de pensar a formação como um ideal ou horizonte regulador de uma atuação educacional frente a um diagnóstico da situação contemporânea, Leopoldo e Silva passa a apresentar a formação em uma acepção mais pragmática ao contrapô-la à noção de 'treinamento'. Tal oposição - que não é total, uma vez que a formação engloba o treinamento como uma de suas etapas, conforme já discutido - é formulada no contexto de uma discussão sobre o papel e potencialidade da Filosofia no currículo do Ensino Médio, frente aos desafios que constituem a especificidade desta etapa de ensino no desenvolvimento do estudante, dado que:

\footnotetext{
A Filosofia se insere numa situação educacional caracterizada, pois, pela ausência de articulação curricular, seja do ponto de vista intradisciplinar, seja da perspectiva interdisciplinar, fatores a que se acrescenta, pelos motivos expostos, também a ausência de articulação entre currículo e formação. (p.159)
}

Deste modo, é a partir de uma reflexão sobre a situação curricular de nossas escolas e sua estrutura de divisão disciplinar que a discussão sobre a relação entre currículo e formação mobiliza a oposição entre as noções de 'formação' e 'treinamento'.

Dito isto, creio que a ideia de formação 'permanece' nas propostas para o ensino de Filosofia nos textos de Franklin Leopoldo e Silva. Dada a situação de fragmentação contemporânea, o autor ainda recomenda como útil a referência aos pressupostos do humanismo moderno, assim como seu imperativo pela autonomia e a busca pela emancipação

\footnotetext{
${ }^{42}$ Ainda que o autor fale em "superação da alienação", entendo que disto não se pode inferir que seja possível anular ou reverter as condições que causaram a alienação, mas somente trazê-las à luz ou torna-las minimamente inteligíveis.
} 
daquele que passa pelo processo formativo que deveria ser a experiência escolar e também um curso de Filosofia no Ensino Médio.

Passo agora a examinar uma outra perspectiva da relação entre ensino de filosofia e formação. Esta parte do pressuposto de que há algo de negativo ou indesejável nos intentos formativos, o que acarretaria em um abandono da ideia de formação ou no descrédito da realização de seu ideal. Examinaremos esta perspectiva em escritos de autores como Walter Omar Kohan e Silvio Gallo.

Em um artigo que se propõe a examinar a relação acima apontada, Kohan afirma que o “ensino de Filosofia continua a ser enquadrado em uma lógica de formação (2003, p.40)" desde a República de Platão. A questão, para Kohan, estaria situada desde a Antiguidade, dos escritos de Platão até os autores contemporâneos, sem que as águas que passaram por debaixo da ponte da Filosofia tenham-na alterado suficientemente. O termo formação, para o autor, seria nada mais do que a fabricação de um certo ideal de pessoa ${ }^{43}(2003$, p. 36), ou seja, os propósitos da formação residiram em um ideal de imprimir uma certa forma nos jovens que irão se tornar os futuros cidadãos e, portanto, governar a república. Importaria, neste ideal formativo, não o que as crianças, os jovens ou os novos são, "mas o que serão, o que podem ser e o que devem ser. (2003, p.37)”.

Se formar é o mesmo que fabricar, supõe-se que seu alvo seja uma massa inerte cuja forma pode ser pré-estabelecida. Ao recorrer a Larrosa (apud KOHAN, 2003, p. 38), explica que a educação que está a serviço da formação deve ser entendida como uma tarefa moral, uma vez que tem como objetivo "com-formar, para dar forma a, a um modelo prescritivo que tenha sido estabelecido previamente. (...) como um ajustar a cada um a aquilo que deve ser".

Isto teria ocorrido pelos laços que a formação veio a instituir com a política, conforme indica Kohan. Quando assim pensada, a Filosofia que adentra as escolas, ou orientada para as crianças, não as têm como o que atualmente são, mas como o que virão a ser: futuros cidadãos com os devidos deveres a realizar em um dado momento futuro.

Desta forma Kohan busca, mesmo que brevemente, apontar para uma "lógica não formativa para o ensino da Filosofia" (2003, p.43-47). Tais apontamentos parecem residir no pressuposto de que se a Filosofia buscar ser um espaço de "experiência do pensamento ${ }^{44}$ ", ela

\footnotetext{
${ }^{43} \mathrm{O}$ autor também aponta que entre as mais diversas vias de discutir o ensino de filosofia, muitas tem como ponto comum estar "a serviço da formação".

${ }^{44}$ Expressão cara também a Silvio Gallo que dá titulo também ao livro por ele editado em 2014 e participante do Plano Nacional do Livro Didático (PNLD) em 2015.
} 
deve recusar o papel de estar a serviço de uma política positiva, seja ela qual for. Assim, um ensino de Filosofia que dá primazia à pergunta passa a tomar o lugar da utopia como princípio orientador. Assim, o perguntar desvincula-se dos projetos e das predeterminações. Não é a polis mais que importa como fundamentação do filosofar, mas a forma de vida que a pergunta possibilita engendrar. Tal perspectiva, que o autor assume, destaca que pensar o ensino de Filosofia nestes moldes passa a situar domínios como a religião, a política ou a moral como objetos de interrogação e não como finalidades anteriores ao exercício da Filosofia.

A mesma ideia de pensar sobre como se dá o ato educativo a partir de um fim prédeterminado também guia Kohan em suas reflexões acerca da forma como a educação lida com a infância. Mas, se no artigo anterior do qual comentávamos, a ideia de formação situava seu ponto fundante na República de Platão, a ideia de uma educação orientada por fins prédeterminados ${ }^{45}$ passa a ser associada ao Iluminismo.

\begin{abstract}
Parece nos que é nessa postura frente à novidade onde se afirmam os alcances conservadores ou transformadores de uma pretensão educativa. Tradicionalmente, a educação não esteve demasiado preocupada com essa novidade. A partir de óticas iluministas - carregadas de categorias como sujeito, progresso, teleologia, razão e verdade - as propostas educacionais são medidas sobretudo em função dos alcances, objetivos e fins predeterminados. Assim, promessas transformadoras, aquelas que se propõem a alcançar um outro estado de coisas frente à ordem dominante, são comumente consideradas como progressistas e aquelas que pretendem manter a ordem vigente são observadas como conservadoras. A importância da educação residiria, antes de mais nada, em sua capacidade para manter ou mudar a ordem existente. Noutras palavras, educamos os novos para transformar ou para conservar o mundo existente. (2005, p.238)
\end{abstract}

O problema para Kohan estaria menos em indicar se a educação a ser dada deve se orientar pela conservação ou transformação do mundo tal como é, do que preservar e afirmar a infância naquilo que apresenta como diferente ou diverso frente ao que já existe. Uma vez que a infância é entendida como a novidade em um mundo que há muito já existia, Kohan aponta que deveríamos lidar com ela sem qualquer tentativa de cooptação em nome de qualquer fim. A novidade já é transformadora por si se acolhida em sua diferença e peculiaridade, por isso que para o autor qualquer educação em nome de qualquer fim prédeterminado é conservador por natureza, pois usurparia este potencial que a infância traz consigo de nos possibilitar a experiência da diferença e da novidade do inesperado. Antes de preparar a infância para que as coisas estejam como estão ou tomem o rumo que dela é

\footnotetext{
${ }^{45}$ No texto que começo a discutir agora, "Uma educação da filosofia através da infância", o termo formação não é utilizado, mas o autor apresenta razões suficientes para que esta educação baseada em motivos iluministas seja entendida como também estando a "serviço da formação".
} 
esperado, entender a infância como afirmação da novidade é o que nos possibilita conceber que é possível "estar em outro mundo diferente do que se está” (2005, p 239).

Desta forma, a educação não deve se pautar para um objetivo futuro, não deve formar ou preparar para coisa alguma se quiser hospedar a pluralidade e dar espaço à diferença. Nestas propostas de Kohan, alerta o autor, não devemos pensar a infância de uma forma idealizada ou romantizada. A tarefa que é prescrita é a de recuperação desta infância, que passa a tomar o norte dos intentos educativos.

Daqui aproximamos as reflexões de Kohan às de Silvio Gallo ${ }^{46}$ para o ensino de Filosofia ou também para a educação, pois aparentam partilharem de muitos pontos e pressupostos em comum. O que parece se confirmar quando encontramos em Gallo a associação entre um certo tipo de intenção formadora e/ou emancipadora de um certo tipo de professor que o autor encontra a partir de uma consideração/distinção feita por Antonio Negri.

\begin{abstract}
Hoje não há mais profeta capaz de falar do deserto e de contar o que sabe de um povo porvir, por construir. Só há militantes, ou seja, pessoas capazes de viver até o limite a miséria do mundo, de identificar as novas formas de exploração e sofrimento, e de organizar, a partir dessas formas, processos de libertação, precisamente porque têm participação ativa em tudo isso. A figura do profeta, seja ela a dos grandes profetas do tipo Marx ou Lênin, está ultrapassada por completo. Hoje, resta-nos apenas essa construção ontológica e constituinte 'direta', que cada um de nós deve vivenciar até o limite (...) Creio, portanto, que na época do pósmoderno e na medida que o trabalho material e o trabalho imaterial já não se opõem, a figura do profeta - ou seja, a do intelectual - está ultrapassada porque chegou a ser total acabamento; e é nesse momento que a militância se torna fundamental. Precisamos de pessoas como aqueles sindicalistas norte-americanos do começo do século, que pegavam um trem para o Oeste e que, a cada estação atravessada, paravam para fundar uma célula, uma célula de luta. Durante toda a viagem, eles conseguiam trocar suas lutas, seus desejos, suas utopias. Mas também precisamos ser como São Francisco de Assis, ou seja, realmente pobres: pobres, porque é somente nesse nível de solidão que podemos alcançar o paradigma da exploração hoje, que podemos captar-lhe a chave. Trata-se de um paradigma 'biopolítico', que atinge tanto o trabalho quanto a vida ou as relações entre as pessoas. Um grande
\end{abstract}

\footnotetext{
${ }^{46}$ Entre os textos de Silvio Gallo, optamos por não discutir o seu mais explorado e influente artigo sobre ensino de filosofia: "A filosofia e seu ensino: conceito e transversalidade" pelo fato de não discutir o tema formação e não conter indícios fortes para relacionar suas teses com o tema. Ainda que sua abordagem siga o mesmo tom e se referencie também em teses de Deleuze e Guattari tal como nos outros textos que aqui abordaremos. Tal texto segue a via de ser mais propositivo para o professor de filosofia que pensa quais caminhos tomar para pensar ou elaborar sua aula. O enfoque deleuzo-guattariano utilizado pelo autor recai sobre a ideia de que a filosofia é uma atividade de criação de conceitos. Assim, sua proposição estabelece quatro passos didáticos, a saber: sensibilização, problematização, investigação, conceituação. Poderia ser profícuo investigar mais de perto, se seguir este caminho implicaria estar demasiado perto de uma noção de que tal aula de Filosofia acabaria por propor que o trabalho de conceituação fosse algum tipo de organização dos dados recolhidos pela experiência no sentido de organizá-lo e ordená-lo, o que parece bastante distante das proposições que observaremos nos escritos de Gallo. Esta possibilidade de hipótese talvez possa ser minimizada, se dermos crédito à sua tentativa de atribuir 'conectividade' ao conceito. Esta conectividade se deve ao caráter rizomático que Gallo encontra nos saberes. $\mathrm{O}$ rizomático se contrapõe ao aspecto arbóreo. A apropriação da ideia de rizoma que ele toma de Deleuze será um lugar comum em vários de seus escritos.
} 
recipiente cheio de fatos cognitivos e organizacionais, sociais, políticos e afetivos ... (apud GALLO, 2002, p. 170)

Se em Kohan a associação entre formação e uma educação para um fim prédeterminado era visto com grandes suspeitas, encontramos na apropriação que Gallo faz de Negri uma recusa a um certo tipo de intelectual, associado à modernidade ${ }^{47}$, que anuncia um porvir tal qual um profeta, para apostar na figura do militante que se mostra mais adequado ao pós-moderno.

Gallo, tal como Kohan, não vê com bons olhos uma educação que situa seu foco ou seus objetivos em um ponto futuro, uma vez que encontra no plano do presente o locus de movimentação das forças que hão de determinar como se dá a ação política ou a ação do educador. O mesmo podemos falar sobre o professor de Filosofia.

O foco da discussão de Gallo não terá seu ponto de partida em um entendimento sobre o que seria a noção de infância, como faz Kohan, mas se orientando pela oposição entre 'educação menor' e 'educação maior'.

\begin{abstract}
A educação maior é aquela dos planos decenais e das políticas públicas de educação, dos parâmetros e das diretrizes, aquela da constituição e da LDB, pensada e produzida pelas cabeças bem-pensantes a serviço do poder. A educação maior é aquela instituída e que quer instituir-se, fazer-se presente, fazer-se acontecer. A educação maior é aquela dos grandes mapas e projetos. Uma educação menor é um ato de revolta e de resistência. Revolta contra os fluxos instituídos, resistência às políticas impostas; sala de aula como trincheira, como a toca do rato, o buraco do cão. Sala de aula como espaço a partir do qual traçamos nossas estratégias, estabelecemos nossa militância, produzindo um presente e um futuro aquém ou para além de qualquer política educacional. Uma educação menor é um ato de singularização e de militância. (2002, p.173)
\end{abstract}

O autor se propõe a operar com uma outra lógica em educação, desvinculando-se das grandes metas ou planos, mas apostando no trabalho 'cru' do chão da escola, entendido como uma resistência, portanto militante. A referência está no trabalho de Gilles Deleuze e Felix Guattari: “Kafka - por uma literatura menor". Transposto o predicativo 'menor' da literatura para a educação, o autor coloca sob suspeita a 'macropolítica' educacional de forma análoga ao que foi dito sobre os "profetas críticos" anunciadores de um porvir típicos da modernidade

\footnotetext{
47 "No âmbito da modernidade, parece-me que podemos dizer que o professor crítico, o professor consciente das suas relações sociais, de seu papel político agiria como um professor profeta. Como alguém que vislumbrando a possibilidade de um novo mundo fazia a crítica do presente e procurava apresentar, então, a partir da crítica do presente, a possibilidade de um mundo novo. O professor profeta é alguém que anuncia as possibilidades, alguém que mostra um mundo novo. (2002, p.170)"
} 
ou sobre a formação para fins pré-determinados formulada por Kohan.

A educação maior é vista como uma "imensa máquina de controle" (p.174) a produzir indivíduos em série. A isto a educação menor deve resistir, uma vez que Gallo acredita que o aprender se dá de outras formas e não se dispõe ao tipo de regulagem que a educação maior intenta. Daí o uso de imagens que o autor busca em Deleuze, em que o ato de aprender é associado ao de um rato no labirinto e de um cão, alegre e furioso, cavando seu buraco. Se notarmos que estes atos são em nada pensados, planejados, antevistos, sendo até mesmo despropositados, a aproximação com os argumentos de Kohan parece ainda mais estreita.

Também aqui se trata de impedir a produção; trata-se de impedir que a educação maior, bem-pensada e bem-planejada, se instaure, se torne concreta. Trata-se de opor resistência, trata- se de produzir diferenças. (...)

(...) Não interessa à educação menor criar modelos, propor caminhos, impor soluções. Não se trata de buscar a complexidade de uma suposta unidade perdida. Não se trata de buscar a integração dos saberes. (p.175)

A resistência proposta se mostra aqui com o objetivo de produção de diferenças. Se a educação maior visa produzir (lembremos do termo 'fabricar' utilizado por Kohan para caracterizar a formação) indivíduos em série, a educação menor deve produzir diferenças ao ponto de recusar prerrogativas - conforme já discutido, associados ao ideal de formação e à modernidade - como a de uma integração dos saberes que possua a pretensão de constituir uma unidade da experiência ${ }^{48}$. Da mesma forma, pensar em modelos, anteriormente prédeterminados, caminhos que já conhecemos que levarão àquela solução já antevista pelo professor, nada farão além de produzir mais do mesmo, ao contrário de uma educação menor que visa singularizar e criar diferenças.

O termo diferença é usado até mesmo para designar uma "filosofia da diferença" que se opõe a uma "filosofia da representação", expressões mais uma vez tomadas de Deleuze. Nesta oposição, podemos encontrar novamente um certo modo de lidar com a Filosofia e/ou a educação que é associada à modernidade ou aos modernos, e que é vista com maus olhos.

\footnotetext{
${ }^{48}$ Tal recusa parece estar aqui colocada não como uma decorrência da situação contemporânea, mas como uma escolha consciente diante de outras possibilidades. Quiçá, esteja aqui um ponto nevrálgico da diferença entre Gallo e Kohan frente à Favaretto nas formas em que analisam o contemporâneo/pós-moderno, assim como aqueles se referenciam em Deleuze e alguns momentos Foucault, e este em Lyotard, mas por vezes também em Deleuze e Foucault. Se o que está sendo aqui sugerido proceder, podemos chamar a postura de Gallo como favorável ao pós-moderno, o que pode ser chamado de um pós-moderno afirmativo?
} 
Como vimos, a educação moderna foi pensada e produzida no contexto da filosofia da representação, tomando o outro como conceito, pensando a formação como sendo a repetição do mesmo. Como, então, pensar uma educação da diferença? Educar a diferença, já não seria domá-la, domesticá-la, reduzi-la ao mesmo? (2010, p.244)

$\mathrm{Na}$ "filosofia da diferença" ou no propósito de pensar uma educação da ou para a diferença, encontramos os mesmo motivos já destacados na "educação menor" ou na suspeita que incide sobre a noção de formação como fabricação. Aqui, no trecho citado o termo formação vem mais uma vez ligada à ideia de produzir o mesmo de operar de acordo com um modelo, o que é rejeitado por Gallo.

Pensar e produzir o processo educativo na ordem do acontecimental significa desmontar a lógica da educação representacional moderna. Significa abdicar do objetivo de formar o sujeito, a consciência, o indivíduo. (p.245)

Para o autor, a ideia de formar um sujeito é apresentada como algo a ser evitado, algo que bloqueia a diferença e a singularidade. Ideia que estaria associada a um projeto moderno que ainda insiste em se realizar, mas que se mostra por vezes como inalcançável, por outras indesejado $^{49}$. A ideia de formação, como pensada por estes autores, ao ser marcada por um fim pré-determinado ou de acordo com um modelo, acaba por ter como principal objetivo o controle ${ }^{50}$.

Disto e de outros apontamentos de Gallo, encontramos dois pontos que merecem ser trazidos à tona. $\mathrm{O}$ primeiro seria o de que, se encontramos tantas vezes a modernidade ou os intentos modernos vistos em chave negativa, ainda assim não encontramos uma defesa ou reclame por uma atitude pós-moderna, como algo oposto ao moderno. A exceção estaria na referência a Antonio Negri, citado páginas atrás. O segundo ponto é o uso da noção de acontecimento, tal como elaborada por Deleuze, que é mobilizada como chave para pensar a educação para além do representacional moderno. Esta noção ou termo, não é de uso

\footnotetext{
49 O argumento que se coloca em oposição a esta de ânsia de controle dos modernos, tem seu aspecto inalcançável a partir da ideia, mais uma vez tomada de Deleuze, de que há algo de incontrolável (GALLO, 2002, p.174) no aprendizado, uma vez que nunca sabemos como e por que alguém aprende algo ou se mostra hábil e desenvolto em alguma arte ou assunto. Em relação ao aspecto do indesejado, pressupõe-se que haja uma escolha entre agir tal como os modernos ou não, como discutido na nota precedente.

50 Associação que é abordada no artigo "Ensino de filosofia e cidadania nas "sociedades de controle": resistências e linhas de fuga" do mesmo autor em parceria com Renata Lima Aspis.
} 
exclusivo de Deleuze e é formulada também por autores como Jean-François Lyotard $^{51}$ e Jacques Derrida.

Se encontramos de forma reincidente em Kohan e Gallo uma visão negativa sobre a modernidade e o pensamento filosófico hegemônico desse período, pode ser-nos útil recorrer a um outro autor que tentou caracterizar de maneira mais detida o que seria o moderno e o que seria o pós-moderno na educação. Ainda que este autor não esteja ocupado com a Filosofia e seu ensino, mas com o debate sobre currículos.

Tomaz Tadeu da Silva, ao tentar discutir as diferentes teorias do currículo que se manifestaram em diferentes períodos históricos, propõe a distinção de tais teorias em tradicionais, críticas e pós críticas. Entre as teorias pós-críticas encontramos o pósmodernismo como uma de suas vertentes.

O pós-modernismo para o autor seria "um movimento intelectual que proclama que estamos vivendo uma nova época histórica (...) radicalmente diferente da anterior, a Modernidade" (2010, p. 111). Para além de quão controversa esta afirmação possa ser ${ }^{52}$, vale destacar que, segundo o autor, é a partir do Iluminismo que encontramos os princípios e pressupostos maiores do modernismo que serão questionados pelo pós-modernismo. Tal questionamento se daria pelo motivo de que algumas ideias centrais do Iluminismo, como ciência, progresso, racionalidade entre outras, estariam na raiz dos problemas a assolar a atualidade.

Não somente aquelas ideias, mas a própria educação, como instituição moderna por excelência, estariam encarregadas não apenas de transmitir os conhecimentos historicamente acumulados, mas também possuiriam a pretensão de formar um ser racional e autônomo, ao mesmo tempo em que o molda como o cidadão da moderna democracia representativa (p.112).

Podemos inferir que é a partir destas pretensões que o autor se refere à modernidade como carregada da ânsia por ordem e controle, que levou à formulação das grandes narrativas,

\footnotetext{
${ }^{51}$ Nos próximos capítulos analisaremos mais de perto a filosofia de Lyotard e a forma como ela possibilita uma aproximação do campo da educação e do ensino de Filosofia. Nestes momentos também dedicaremos atenção especial à noção de acontecimento proposta por este autor.

${ }^{52}$ Esta ideia, apresentada por Tadeu da Silva, não será aceita por muitos autores. Favaretto, por exemplo, aponta em Giorgio Agambem um parecer bastante distinto: "E é exatamente a sua obscuridade, lembra Giorgio Agambem, que caracteriza o contemporâneo - um tempo crítico que só pode ser surpreendido em relação a outros tempos, que por sua vez também foram contemporâneos. Assim, hoje só podemos falar em contemporâneo em relação ao que foi moderno, ou que ainda é moderno. A contemporaneidade é, assim, simultânea à modernidade. (2012, p.1)
} 
típicas da modernidade, que acabavam por funcionar como via explicativa geral dos fatos e fenômenos de acordo com sua perspectiva exclusiva e totalizante.

No entanto, desta obsessão totalizante que a modernidade traz consigo, as consequências teriam sido algo muito distante da sociedade perfeita sonhada pelos iluministas. Seu verdadeiro resultado foi uma sociedade totalitária e burocraticamente organizada.

De forma a contestar esta atitude, Tadeu da Silva afirma que nosso tempo pode ser considerado como portador de uma identidade pós-moderna que é múltipla, descentrada e fragmentada (p.114).

Não se trata de atribuir o rótulo de pós-moderno a autores como Kohan e Gallo, ou qualquer outro rótulo ou filiação a movimentos. Sequer termos como pós-modernidade ou pós-moderno são usados por estes autores nos seus textos aqui discutidos, como já apontado. No entanto, é perceptível o grau de similaridade entre os questionamentos que Tadeu da Silva relata com as diversas suspeitas que Kohan e Gallo dirigem à "educação maior" ou à formação como fabricação. Creio não ser exagerado que tanto na escrita destes como na daquele, encontramos uma concepção comum sobre o que é a modernidade e o que é o Iluminismo.

Por ser tal caracterização tão negativa a ponto de propor a rejeição dos princípios iluministas ou modernos para a educação ou para o ensino de Filosofia, acredito ser razoável afirmar que a postura destes autores é de um afastamento do ideal de formação ao ponto de um total descrédito e abandono.

Ainda há, em ao menos um outro autor, uma perspectiva que não coincide totalmente com aquelas que encontramos nos autores anteriormente discutidos. Imaginar que o ideal de formação não possua o vigor ou crédito de outrora, ou até mesmo aceitar a falência do projeto moderno, em algum sentido, não precisa implicar em seu completo abandono. A discussão sobre a falência do projeto iluminista ou moderno pode ser em algum sentido esclarecedor, ou seja, talvez seja importante ou até mesmo necessário revisar os fracassos daquela agenda e investigar as razões para isto. Da mesma forma, retomá-lo sem saber o porquê do seu insucesso é algo que não pode ser aventado ${ }^{53}$.

\footnotetext{
${ }^{53}$ Caracterizar a via de Franklin Leopoldo e Silva desta maneira apressada, não é a leitura que aqui foi proposta. A persistência do ideal de formação apenas permanece como ideal regulador e não como objetivo último
} 


\begin{abstract}
Assim, estas considerações põem em relevo, repetimos, a necessidade de se pensar a educação no horizonte das transformações contemporâneas, da crítica das ilusões da modernidade e da necessidade de se proceder à reorientação dos seus pressupostos o que implica pensar o deslocamento do sujeito, a produção de novas subjetividades, as mudanças no saber e no ensino, a descrença dos sistemas de justificação morais, políticos, estéticos e educacionais e as mudanças dos comportamentos. Trata-se, mais precisamente, de se reconsiderar a fundamental idéia de formação e de reexaminar as justificativas e os pressupostos da crença nos tradicionais componentes do processo educativo. É disso tudo que se trata quando nos propomos a pensar as questões educativas e culturais sob a perspectiva da nossa atualidade, da qual somos contemporâneos, tendo, contudo, como referência o pensamento iluminista, que ainda é determinante em grande parte do que somos, pensamos e fazemos hoje, ainda que seja insuficiente para dar conta da indeterminação e do insuportável da experiência contemporânea. (FAVARETTO, 2012, P.7,8)
\end{abstract}

Nesta citação de Favaretto, já é possível reter uma informação estratégica para nossos intentos: "a fundamental ideia de formação" não será simplesmente retomada ou reformulada, muito menos posta de lado. O caminho proposto será o de seu reexame, no sentido de reconsiderar suas propostas em seus sucessos ou em seus fracassos, mesmo que estes possam ser considerados como mais evidentes ou notáveis. Mais do que isso, é preeminente que isto seja feito tendo como referência o pensamento iluminista, pela força que ainda possui em determinar o modo pelo qual pensamos ou agimos. Ou seja, não é por uma decisão espontânea que rompemos com o Iluminismo ou nos declaramos não iluministas ${ }^{54}$. Pelo contrário, é preciso adotar a via de examinar a que ponto ainda nos referenciamos neste movimento e em que sentido ele nos levou a situação contemporânea. Isto não implica em afirmar que o pensamento iluminista guarda a chave para entendermos o que se passa hoje. Favaretto é claro ao afirmar que tal referência não será suficiente para dar conta da indeterminação e do insuportável da nossa experiência. No entanto, ainda assim será indispensável.

Desse modo, o Iluminismo, ou qualquer outro grande discurso de legitimação - se quisermos utilizar o léxico lyotardiano -, não oferece uma linguagem para colocar as coisas em seus devidos lugares, ou reestabelecer algum tipo de ordem a ponto de satisfazer nossos desejos de conferir-lhes sentido. Desejos que, em geral, recaem na forma de tarefas legadas à educação.

perfeitamente alcançável e que por esse motivo pode ser retomado. Afirmar isto, colocaria o autor próximo de algumas teses de Jürgen Habermas em textos, polemizados por vários autores, como "A modernidade: um projeto inacabado", aproximação que não parece nem um pouco razoável.

${ }^{54}$ Este argumento parece ser baseado no texto de Foucault, citado por Favaretto, "O que são as luzes", em que o filósofo francês recusa a imposição de uma escolha "simplista e autoritária" entre ser a favor ou contra a Aufklärung, uma vez que ela a caracteriza como sendo um "conjunto de acontecimentos políticos, econômicos, sociais, institucionais, culturais dos quais somos ainda em grande parte dependentes, constitui um domínio de análise privilegiado (2005, p. 345)”. 
Algo ocorre com o estatuto do saber, uma vez que ele não é mais "magnetizado por uma ideia, como aquela do projeto moderno de emancipação da razão e da liberdade humanas" (1991, p. 121), na situação pós-moderna, postula Favaretto a partir das análises de Lyotard em "A condição pós-moderna". Como situar as tradicionais tarefas habitualmente legadas à educação quando a atualidade passa a ser afetada por transformações substanciais no campo tecnológico e informacional, de modo a desafiar nossos usuais entendimento e concepção sobre o que é o saber e para que ele deve servir?

Em sua análise sobre o modo como se configura a atualidade, ao tentar colocar em questão quais podem ser nossas ações no campo educacional - ou quais tarefas ainda podem ou se devem ser colocadas - o autor ressalta dois pontos para se entender as transformações modernas: por um lado é possível notar que há um deslocamento cada vez maior das fronteiras conceituais e históricas nos mais diversos campos do saber ou áreas do conhecimento; por outro, a experiência contemporânea alcança um nível de indeterminação que a dota de um caráter da ordem do insuportável (FAVARETTO, 2012, p. 2,3; 1991, p.121).

É importante notar que estes dois pontos colocam em xeque duas expectativas que recaem sobre o ideal de formação, assim como sobre o espírito do Iluminismo, uma vez que suas "fontes são a razão e a experiência, na tentativa de realização da razão no indivíduo e na história, tendo como finalidade a emancipação (2012, p. 8)". Assim, os deslocamentos conceituais rompem a esperada univocidade do saber, a qual o processo de formação visava atingir ou realizar. Algo próximo também pode ser dito da experiência que deixa de cumprir o esperado papel de guia condutor para a emancipação, tornando-se somente um elemento de perturbação e indeterminação.

Visto que se deposita na educação a esperança pela continuidade de uma sociedade e de suas instituições, ainda é possível perceber nos discursos vigentes um impulso para tratar a questão educacional como se pudesse compor uma totalidade (1991, p.122), daí a necessidade de que suas ações sejam orientadas por um princípio de reunificação da experiência - do qual o ideal de formação visaria atingir - que traria consigo também uma expectativa por alcançar valores consensuais que possam ser transmitidos ou formados (2012, p. 6).

Entender que nossa percepção da experiência seja fragmentada - e que o acesso ao saber não mais nos proporciona sua unificação nem mesmo pode formar uma unidade que se manifeste de maneira inteligível - é algo que encontramos muito antes de tempos ditos pósmodernos. Tal preocupação e intenção já encontrávamos nos escritos de Schiller, como 
reportado no capítulo inicial. O que é colocado em questão aqui é algo diferente. O dilema que aponta Favaretto, e desafia a ação dos educadores na contemporaneidade, é de outra ordem:

(...) com que espécie de unidade sonham os educadores: Aquela, sócio-cultural moderna, em que todos os elementos da vida cotidiana e do pensamento encontrariam um lugar como em um todo orgânico? Ou uma outra ordem, em que os jogos de linguagem heterogêneos (os do conhecimento, da ética, da política) se cruzam, se superpõem, sem aspirar a uma síntese efetiva?

(1991, p.122)

Duas vias são apresentadas, uma vez que o campo da educação é confrontado com a situação contemporânea ou pós-moderna. Uma mais próxima às teses de Habermas ${ }^{55}$, outra mais próxima às proposições de Lyotard. Ora, uma vez que Favaretto faz uso do diagnóstico sobre a pós-modernidade feita pelo filósofo francês, as posições de Habermas acabam por se mostrarem bastante despropositadas. Ainda assim, o problema permanece, uma vez que a passagem sugere que algum tipo de unidade possa ser aventado, mas que venha a se manifestar sem violentar a heterogeneidade ou singularidade dos jogos de linguagem que se entrecruzam.

Antes de tentar entender ou decifrar o que seria uma unidade sem síntese, cumpre notar que Favaretto coloca as intenções habermasianas como manifestações de um "impulso conservador" desesperado face à desterritorialização dos domínios do saber e do conhecimento que acorrem aos indivíduos. O pânico a que se refere o autor (1991, p. 122, 123), seria decorrente de não sermos capazes de encontrar uma "linguagem que esteja à altura de traduzir o estado atual das coisas". Um movimento por reterritorialização passaria por esta linguagem que se encontra em lugar algum. O impulso conservador habermasiano tentaria, nesta perspectiva, forjar esta metalinguagem que voltaria a colocar cada coisa em seu lugar, dando dimensão ou valor inequívocos para cada fenômeno ou acontecimento.

Próximos a este movimento de reterritorialização estariam tanto uma "atitude reativa" quanto uma tentativa de "resgate de valores" (1991, p. 123, 124). Tais propostas visariam enfrentar "a banalização, a dessubstancialização e a individualização do conhecimento e da experiência, a atomização programada que rege o funcionamento das sociedades capitalistas". Favaretto comenta que os discursos que apontam para tal direção se esforçam para encontrar algum tipo de redenção, de forma a reconstituir um passado ou uma origem anterior aos danos

\footnotetext{
${ }^{55}$ Conferir nota 53.
} 
ou erros que ocasionaram a situação presente. Assim, seria possível remontar um cenário sem a marca dos erros e dos crimes que nos assolam no cenário atual.

Um outro caminho é apontado pelo autor: o da reiteração, que é proposto a partir do recurso que Lyotard faz à terapêutica psicanalítica. Um trabalho que se aproxima ao da anamnese que se ocuparia de buscar o que havia de implícito nos projetos modernos, naquelas realizações que se deram sem saltar aos olhos, mas que podem ter sido mais ou menos determinantes para o que teria resultado no cenário atual. Buscar estes elementos através da reiteração não deve nos levar ao objetivo de tentar ou evitar repeti-los, mas de trazê-los em relevo, ao ponto de encontrar suas específicas diferenças, a fim de compor um estoque cultural que possa estar à disposição para fins não determinados de antemão.

Deste caminho proposto, em que a relação que temos com o saber começa a adquirir outros contornos, o autor propõe que é necessário ir ao encontro de uma certa concepção estratégica para o saber. Propor-se-á, então, que o perspectivismo se encarregue de tal relação estratégica a se ter com o saber e com a produção dos conhecimentos (1991, p.124, 125). Relação que pretende estabelecer como atuam as diversas forças em um determinado campo, de modo a saber como estas atuam e se tensionam umas com as outras. Desta forma, o trabalho que é proposto passa a ser mais interpretativo do que elucidativo ou explicativo.

Sendo este o quadro da situação contemporânea ou pós-moderna, desafiando os educadores de nosso tempo, como devemos pensar o ensino de Filosofia? Quais propostas ou intenções estariam mais ajustadas à tal condição?

As dificuldades estariam precisamente no ato de assumir o valor formativo que tradicionalmente associamos à Filosofia, de modo a imaginar que este valor implica não somente na unidade da experiência, mas também em um requisito de sistematicidade. Ainda assim, Favaretto ressalta que para além desta pretensa visão de totalidade, que estaria na intenção formativa que a Filosofia - e também em seu ensino - traz consigo de forma implícita, também poderíamos considerar que há muito tempo a Filosofia também se mostra resistente a totalizações (2004, p.43). Ao não se fixar no mesmo lugar, cambiando seus temas e lugares de enunciação, é possível afirmar que a Filosofia recusa-se a se colocar no posto de um saber soberano, ainda que tentativas neste sentido tenham sido feitas um sem número de vezes. Esta resistência que podemos caracterizar a partir do movimento de fluidez ou de deslocamento daquilo que chamamos de Filosofia em sua história, a impediria de ser colocada tal como um saber cadastrado. 
Mesmo a Filosofia sendo entendida desta forma, ela ainda guarda alguma sorte de conexão com a ideia de formação, tomada como "a ideia de que o espírito humano está sempre à espera de algo que o leve a cumprir-se". Assim a formação é entendida como um processo que ao seu término desencadearia na conquista da autonomia de pensamento e existencial do educando, resultando assim em sua emancipação.

Mas se a Filosofia, como caracterizada por Favaretto, é enfatizada em seu caráter múltiplo e disperso, ela não poderá se colocar em curso tal como a imagem tradicional de formação supõe. Ao entender que - seguindo a trilha de Lyotard - a Filosofia está sempre "em curso", no meio ou ao longo de algo que ainda acontece, ela não pode ser confundida como algo que se finda ou que se dá ao completar de um processo. Ainda assim, nesse exercício de pensamento, talvez seja possível encontrar uma tônica formativa que nos leve a pensar que a formação pode ainda ocorrer, mas não como ...

(...) algo que decorre do que se aprende na filosofia, mas que é destilado nas variadas operações do pensamento, que mantêm a especificidade das singularizadas expressões da filosofia. Um reexame dos pressupostos e subentendidos dos discursos permite entender o trabalho filosófico e surpreender a sua tônica formativa pela elaboração que, ao articular o que está em curso como o que foi cursado, dá acesso ao impensado no que já foi pensado (2004, p. 44).

A ideia de formação que passa a ser proposta provém não de um esforço por sistematizar conhecimentos dispersos, mas daquele de ressaltar cada operação do pensamento ou cada modo de enunciação ou configuração de problema que a Filosofia em sua pluralidade proporciona. Encontramos também nesta passagem mais uma vez o recurso à ideia do trabalho psicanalítico da anamnese, tal como recomendado por Lyotard. O trabalho de reiteração que era proposto para fazer frente aos discursos tão abundantes de "perda do sentido" ou de "resgate de valores", aparece no trabalho de reexame dos pressupostos e subentendidos que podem estar mais ou menos implícitos nos discursos que acessamos na leitura dos textos de Filosofia. Tentar encontrar o "impensado no que já foi pensado" vai ao encontro do esforço de coletar tudo o que não estava explícito naqueles projetos modernos, mas que em sua realização mostraram estar presentes de forma imprevista e que agora passam a estar disponíveis para fins diversos.

Tal trabalho de anamnese, indica o autor, radicaria naquilo que seria o essencial da atividade filosófica: a leitura filosófica. Esta se apresenta, usando mais uma vez os termos tomados de Lyotard, como um "exercício de escuta" (1985, p.80, 81). Exercício que opera na 
mesma forma de reexame dos sentidos imanentes a um texto sejam eles claramente expressos ou implícitos tal como era apontado. Portanto uma leitura que funciona como elaboração e portanto requer paciência pois não se finda e muito menos se propõe a encerrar um processo podendo sempre ser retomado por uma nova perspectiva, se quisermos aderir à proposta de perspectivismo como sugerida há pouco.

O trabalho a ser desenvolvido em aula pode se assemelhar também ao de um “egiptólogo", sugestão que Favaretto pesca em Gilles Deleuze ${ }^{56}$. A proposição consiste que cada objeto passível de ser conhecido, ou a partir dele aprendermos algo, emite signos. Aprender seria então uma arte de se tornar sensível aos signos e às suas emissões a ponto de nos familiarizar com eles. Tal exercício implicaria em podermos nos apoderar destes signos, e de seus possíveis usos, uma vez que se encontram decifrados (2004, p.45)

Seja no trabalho de anamnese que leva sempre ao paciente exercício de escuta ou na decifração de signos à maneira de um "egiptólogo" encontramos uma mesma dificuldade que está relacionada aos interesses dos alunos. Se entendermos, como aponta Favaretto, que os alunos têm seus interesses já fixados, dada a homogeneização da cultura e também pela tendência que existe ou o hábito que possuem de criticar as coisas de forma imediata, o trabalho de desconcertação paciente dos sentidos do texto ou de decifração de signos se coloca em sentido completamente oposto. $\mathrm{O}$ autor enfatiza que a crítica não pode anteceder as condições que a possibilitam (2004, p.46). O ensino de Filosofia deveria contribuir para formar nos alunos tais condições que passam pelas propostas que ressaltamos. Mais importante ainda é sublinhar que a crítica, para ser exercida, leva tempo e não pode ser feita com pressa. Trabalho que será necessariamente árduo para ser feito em aula, uma vez que sabemos como o imperativo do "ganhar tempo", do sucesso e do prazer aderem ao pensar, ao agir e aos desejos dos alunos.

\begin{abstract}
Eis, então, uma posição quanto à ideia da formação pela filosofia: a filosofia gera condições, indiretas é claro, da intervenção na realidade, nos modos dos jovens se situarem face à multiplicidade e heterogeneidade dos problemas, fatos, acontecimentos em que estão envolvidos. Intervir significa então descobrir o funcionamento e o sentido das configurações (teorias, ideologias e mitologias, religiosas, científicas, tecnológicas, artísticas); significa interrogar, formular questões e objeções. Para isso, reafirmando, os jovens utilizam os sistemas de referência constituídos no curso de filosofia, como uma experiência (acima de tudo, sobre os processos enunciativos) de uma diversidade significativa de trabalhos filosóficos." (2004, p. 46)
\end{abstract}

\footnotetext{
${ }^{56}$ A referência é feita a partir da obra "Proust e os signos", que curiosamente não é utilizada por autores como Kohan e Gallo, que se apoiam em diversos conceitos e noções do referido autor.
} 
Apropriar-se destes sistemas de referências ou dos procedimentos de interrogação, assim como tentar se familiarizar com os mais diversos signos que se apresentam exigindo diferentes modos de interpretação não ocorrerá facilmente. Mais do que notar sua dificuldade, é preciso entender que se trata de um processo que leva tempo. Das colocações feitas por Favaretto para pensarmos acerca de como deve ser o ensino de Filosofia, percebemos que todas elas encerram uma certa relação com o tempo, que é radicalmente oposta à relação que o mundo ensina aos jovens. Se o ideal de formação em sua imagem tradicional também carrega consigo o tempo que leva para o completar de sua jornada, esta nova imagem de formação que encontramos aqui forjada parece conservar, em certa medida, esta relação com o tempo. Talvez seja possível inferir que tal relação é extrapolada, uma vez que não se tem mais em vista a completude do processo, antes almejada.

A possibilidade de pensar a ideia de formação, um tanto deslocada de sua tradicional imagem, ainda que sem se colocar de maneira radicalmente oposta àquela, pode ser facilitada pela menção que Favaretto (1995, p.78-80) faz a uma reflexão de Gerárd Lebrun sobre o posicionamento dos jovens diante das potencialidades da Filosofia.

Nunca acreditei que um estudante pudesse orientar-se para a filosofia porque tivesse sede de verdade: a fórmula é vazia. É de outra coisa que o jovem tem necessidade: falar uma língua da segurança instalar-se num vocabulário que se ajuste ao máximo às "dificuldades" (no sentido cartesiano), munir-se de um repertório de "topoi", em suma, possuir uma retórica que lhe permitirá a todo instante denunciar a "ingenuidade" do "cientista" ou a "ideologia" de quem não pensa como ele. Qual melhor recurso se lhe apresenta senão tomar emprestado um discurso filosófico?

(LEBRUN, 1976, p. 151)

A recusa de Lebrun por partir do pressuposto de "sede de verdade' não é corriqueira. Essa suposta sede está implícita no ideal de formação ${ }^{57}$, tal como conhecemos. Ao propor um afastamento deste - sem seu total abandono -, o pressuposto é trocado por algo que possa estar mais próximo do universo dos jovens alunos que é a necessidade de falar uma "língua de segurança" que, pelas indicações do autor, funciona mais como uma retórica do que como um saber positivo sobre as coisas. O jovem não é mais tomado como alguém que aspira a um saber, que quer modificar sua relação com o mundo e consigo próprio a partir da aquisição de saberes ou neles progredir. A relação que o jovem almeja seria outra, a de se situar melhor

\footnotetext{
${ }^{57}$ Percebemos os mesmo no Bildungsroman, o herói que se engaja na aventura formativa, o faz pois busca algo nela, anseia para percorrê-la em busca de algum tipo de resposta, conhecimento ou alívio de inquietudes.
} 
perante os desafios ou jogos que a vida contemporânea lhe impõe. Para isso uma linguagem ou ao menos um conjunto de referências - apropriada se faz necessária, para que lhe assegure, em certa medida, a possibilidade de enfrentar tais desafios.

A aproximação desta proposta da aquisição de instrumentos (retóricos?) para constituir uma língua de segurança conjugada com o diferendo entre os idiomas falados pelo mundo e pelo "curso filosófico" apontado por Lyotard possibilitam a Favaretto conceber ainda alguma conexão entre a ideia de formação e o ensino de Filosofia, ainda que despida de parte daquelas motivações antes apontadas. A ideia de emancipação talvez não possa ser colocada como objetivo último ${ }^{58}$ como antes, mas pensá-la como impossível de ser alcançada, tanto antes como agora seria igualmente reativo. Reorientar se para o exame dos motivos de sua não realização é o que pode promover uma nova ideia de formação que colabore para uma emancipação cuja forma será dificilmente prevista.

Ainda há um elemento na imagem tradicional do ideal de formação que é propício trazer à pauta ao discutirmos o ensino de Filosofia. A relação entre a Filosofia e a ágora, ou seja o espaço público de debate e de deliberação política, em que se manifestam a isonomia e a isegoria.

Ricardo Fabbrini ${ }^{59}$ ao examinar tal relação, expõe que se há ainda algum lugar no mundo atual que pode ter semelhança com a ágora, este lugar é a sala de aula. Seja qual for o grau ou dimensão desta semelhança, o autor indica que a sala de aula manifesta-se como ágora residual por ser "o único lugar, em tempos de suposto "pensamento único", em que ainda se pode amar as discussões" (2005, p.18).

Para se configurar como um espaço onde esta philia se manifesta em oposição ao pensamento único, é importante que o autor destaque que a discussão em sala de aula não possa ser aprisionada pela esfera da "opinião corrente (...), da doxa mass-mediática (2005, p.12)",

A vinculação à Bildung, ao ideal de formação, teria sua possibilidade inscrita pelo exato motivo de que o exercício de escuta negaria a instrumentalização da linguagem.

\footnotetext{
${ }^{58}$ Aqui não é inoportuno repetir: a diferença que encontramos nos posicionamentos de Favaretto e de Leopoldo e Silva não é o de continuidade na aposta pela emancipação contra o seu descrédito. Leopoldo e Silva a mantém como norte para os projetos, Favaretto parece apontar para a reelaboração de seus propósitos a partir de sua não realização.

${ }^{59}$ Em seu textos sobre o ensino de filosofia: "O ensino de filosofia no $2^{\circ}$ grau: uma língua de segurança" ou "O ensino de filosofia: a leitura e o acontecimento", encontramos uma discussão que segue muito próximo a trilha de análise proposta nos textos de Favaretto, contendo não somente referências em comum, mas também proposições bastante próximas ou análogas, o que é consentido em uma das notas de rodapé do segundo artigo.
} 
Fabbrini sugere a associação entre uma imposição da racionalidade instrumental ao falar dos alunos, com a noção do idioma da troca econômica que o mundo ensina aos jovens. Assim a noção do idioma da 'realidade', que é oposta ao idioma do curso filosófico nas proposições de Lyotard, teria seu fundamento na racionalidade instrumental ${ }^{60}$. Resta saber se as pretensões da Bildung seriam coincidentes em algumas medidas com aquilo que o 'curso filosófico' com seu exercício de escuta à leitura e aproximação da anamnese operariam ${ }^{61}$.

De uma forma ou de outra, o apelo para que a aula de Filosofia se paute em se aproximar da imagem da ágora se dá menos pela exigência de atuação na esfera pública após ultrapassar a etapa da formação escolar, do que por uma relação outra com a linguagem, que deixa de ser instrumentalizada ou colonizada pela técnica. A sala de aula só poderá ter semelhanças com a ágora grega se puder constituir algum tipo de epokhé (2005, p.16), em que os critérios da dita realidade se encontrariam em suspensão, para que os alunos tenham outra relação com a linguagem, agora pautada pelo paciente exercício de escuta, similar à da anamnese.

Ao apresentar três possibilidades de propor relações entre o ensino de Filosofia e o ideal de formação, tentei marcar as nuanças que o sentido do termo ou da noção de formação apresentam entre os diferentes autores e textos. O que não implica que seja impossível encontrar pontos de encontro nas propostas dos autores ou nos pressupostos que fundamentam suas propostas.

Ainda que os textos aqui analisados não estejam todos preocupados com a temática específica do ensino de Filosofia, ou com a necessidade, a especificidade e as vantagens de sua implementação nos currículos do Ensino Médio, todos eles dão especial atenção à questão do contemporâneo ou da atualidade. Nenhum texto, ao pensar a Filosofia em relação às questões e desafios do tempo presente ou do mundo contemporâneo, se descola totalmente destas.

Ao voltarmos nossos olhos para os recortes temáticos, recursos conceituais, fontes bibliográficas e autorais ou aos tipos de abordagem realizadas, teremos a confirmação da preocupação dos autores em pensar o ensino de Filosofia como algo minimamente ajustado

\footnotetext{
${ }^{60}$ Aqui curiosamente, Fabbrini opta por um curso que parte das proposições de Lyotard, como a do exercício de escuta à leitura, como recurso de oposição à racionalidade instrumental. Neste ponto estaria localizada a justificação da vinculação do ensino de filosofia ao ideal de formação. Parecer que estaria mais próximos das propostas de Leopoldo e Silva do que das de Favaretto.

${ }^{61}$ Discussão que será encaminhada no capítulo seguinte conjuntamente com outros tópicos da filosofia de Lyotard, conforme já foi indicado na nota 51.
} 
aos tempos atuais, e de alguma forma significativa para a vida do jovem e o modo como este se insere na configuração da sociedade em suas diversas esferas.

Isto não significa que qualquer recurso à temas, debates ou autores muito afastados de nosso tempo não possa servir de importante recurso para pensarmos o ensino de Filosofia. Muito menos que devemos a todo custo atualizar a Filosofia ou abordá-la somente com a necessidade de servir se dela para nos auxiliar pragmaticamente. ${ }^{62}$

O que parece estar contido nas proposições dos autores, em diferentes medidas, seria conceber de que Forma a Filosofia pode contribuir para o jovem em sua escolarização, ou melhor, o que poderia convir para sua formação ${ }^{63}$.

${ }^{62}$ Pensar nesta chave parece estar muito próximo da perspectiva que Pegoraro apresenta para o ensino de Filosofia, conforme citação no início do capítulo.

${ }^{63}$ Claro está que Kohan concebe a ideia de formação em chave negativa. Esta só seria admitida se pensada sem um fim prescritivo que determinasse de antemão a forma que o ensino tomaria, ou estivesse subjugado àquilo que os alunos devessem se tornar após o fim do processo de formação. 


\section{O acontecimento, o diferendo e a escritura. Tópicos lyotardianos e a educação.}

$\mathrm{O}$ que se espera que aconteça em uma aula de Filosofia? Feitas as discussões e reflexões dos capítulos precedentes, é razoável afirmar que não podemos esperar que os alunos se encontrem sedentos ou ansiosos por conhecimentos, menos ainda que nossas aulas assim como as outras - possam ser orientadas pela expectativa de formar o aluno emancipado.

Não estamos mais providos da mesma retaguarda ou fundamento da expectativa formativa que a modernidade e o Iluminismo nos legaram. Mas também não colocamos os dois pés completamente fora deste período com todas as suas prerrogativas ou esperanças. Ao concordarmos com o parecer de Foucault (2005, p.345) de que não podemos ser manifestamente antipartidários da Aufklärung, em parte a razão para isto pode estar no motivo de ainda sermos, em muitos aspectos, por esta constituídos.

Reconhecemos que a tarefa emancipatória da metanarrativa iluminista não foi alcançada tal como se esperava, e acreditamos cada vez menos em sua promessa. Tampouco continuamos a olhar para o futuro com a esperança que trazíamos outrora. Neste cenário, que tem um pouco de desesperador e também de melancólico, ainda podemos esperar algo da Filosofia que passa a se fazer presente nos currículos do Ensino Médio? Se a expectativa de outrora não mais é posta, há algo ainda a se esperar?

Ao encaminhar as questões desta forma, após as considerações pinçadas dos autores do capítulo anterior, é que podemos transitar por algumas ideias e reflexões presentes em diferentes obras e textos de Jean-François Lyotard que recaem, direta ou indiretamente, sobre o campo da educação.

Respostas definitivas não serão encontradas, mas indícios e sinais que talvez apurem mais nosso faro para melhor colocar as questões que possam dar expressão aos desafios feitos a nós. Isto, caso estivermos dispostos a não fazer tábula rasa das intenções, explícitas ou implícitas, dos projetos mal-fadados da modernidade, menos ainda em crer que partimos de um ponto zero ou de uma etapa nova completamente aberta para novas iniciativas.

“A educação tem pois um papel fundamental - o da escola francesa desde há dois séculos: fazer com que a nação se torne uma República de direito" (LYOTARD, 1993b, p. 49). Sendo este o objetivo que a modernidade e as Luzes legaram à escola, assim como a ideia de formação como emancipação se tornou vinculada, não somente à educação, mas também à Filosofia, o que ocorreu foi tanto a não realização deste intento quanto o declínio e perda de credibilidade destes ideais. Alguns dos motivos disso já foram expostos aqui, mas também 
não podemos esquecer o quanto de atrocidades foram cometidas em um espaço de duzentos anos, ou mais, supostamente em nome destes ideais (id, ib.).

O que passamos a examinar agora, a partir da leitura de textos de Lyotard, é que a tentativa de efetivação destes ideais legou ao nosso tempo algo mais do que desesperança, desilusão ou descrenças. Não se trata de um esforço para sermos menos pessimistas em nossos intentos educacionais, mas precisar melhor o alcance de nossas possibilidades, uma vez que o princípio de fundamentação de nossa ação é cada vez mais posto em xeque.

Após o intenso debate que a obra "Condição pós-moderna" propiciou, Lyotard pode reconsiderar o uso do prefixo 'pós' a preceder termos como 'moderno' ou 'modernidade'. A expressão passou a ser tomada de maneira equívoca e dúbia, sugerindo um período temporal ou histórico de marcas próprias e distinto do precedente. Não era isto que estava sendo proposto, como tentou demonstrar em entrevistas, cartas e artigos: "Não se entra numa nem se sai de outra como se muda de divisão ou de casa. É a divisão, ou a casa que muda. Reconhecêmo-la ou não a reconhecemos. A palavra pós-modernidade é suficientemente equívoca para designar esta incerteza. (id, ib.)".

Nesta obra, que se tornou a mais celebre e discutida do autor, encontramos principalmente o objetivo de marcar "a posição do saber nas sociedades mais desenvolvidas (2011, p. xv)" de modo a tornar mais perceptível qual era o estatuto do saber naquele momento, de acordo com as transformações dos mais diversos campos durante a segunda metade do século XX. Não era, pois, questão de distinguir um período ou caracterizar uma nova fase, mas antes notar uma condição ou um cenário com suas marcas distintas, em maior ou menor grau, se comparados a outros.

Falar de uma 'condição pós-moderna' ou de um 'novo cenário' não implica deixar de tomar a modernidade como problema. Postular que seus projetos não se realizaram não equivale a determinar seu término ou esgotamento. Antes, o cenário contemporâneo pode ser pensado como ocasião daquilo que Lyotard chamou de "reescrita da modernidade".

Ao aventar essa possibilidade, Lyotard pretende evitar os seguintes entendimentos: 1Reescrita no sentido de começar algo do zero, isento de pressupostos, como se os ponteiros de um relógio fossem reposicionados em seu ponto inicial. 2- Reescrita como uma relembrança que se encarrega de identificar e reparar os crimes e erros localizados em um momento passado. Reescrever a modernidade neste segundo sentido seria apenas ir em busca do ponto preciso em que algo saiu do planejado, e impediu a realização de seu projeto. Para o autor, tal tentativa não faz mais senão repetir e perpetuar o erro sem dar-lhe um fim. 
Por via distinta, considera Lyotard (1989, p.38-40), reescrever guarda parentesco tanto com a techné do analista freudiano quanto com a busca do artista em propiciar o efeito do gosto em seu público. Tal techné consiste na atenção flutuante que o analista deve ter ao escutar seu paciente de modo a seguir a regra de suspender preconceitos ou qualquer tipo de julgamento dando a mesma atenção a todo e qualquer tipo de acontecimento, inclusive na forma em que acontece, relatado pelo paciente. Este, por sua vez, também deve dar curso livre a todas as ideias, nomes, cenas que o ocorrerem sem nenhum tipo de seleção. Tal trabalho decorre da dissociação proposta por Freud entre perlaboração (Durcharbeitung) e relembrança (Erinnerung) ${ }^{64}$. Tal procedimento realizado na análise seria conduzido por esta tentativa de perlaboração que, a partir do que foi livremente captado pela techné do analista no fluir de relatos de seu paciente, acaba por constituir um quadro ou uma cena, a qual deve ter uma relação com algo acontecido em um passado mais ou menos distante. Não é possível saber o que realmente se passou. Lyotard argumenta que o conhecimento de um objeto ou de sua causa não está em jogo, pelo fato de que a análise não está sujeita ao conhecimento, mas à arte. Algo muito semelhante se passa com a intenção e ação do artista do belo ao querer provocar tal efeito em seu público, de acordo com o Kant da terceira Crítica. Não há domínio do artista sobre este efeito, ainda que haja intenção de provocá-lo. O juízo do belo não se apoia sobre um objeto de conhecimento. Não há um conceito do belo que uma vez alcançado através de uma pesquisa, possa ser posteriormente aplicado.

O que Lyotard busca com estas referências a dois atos distintos - o trabalho de criação das Belas Artes, mesmo sem um conceito de belo, e a análise freudiana que se exime de recuperar e expor um passado originário das neuroses do paciente - é a relação que a modernidade tem com seus fins e como a sua reescrita elabora uma nova relação.

É possível agora clarificar uma segunda acepção, diferente, deste 're-'. Ligado de maneira fundamental à escrita, ele não significa de maneira nenhuma um retorno ao começo mas, de preferência aquilo que Freud designou por 'perlaboração', a Durcharbeitung, ou seja um trabalho dedicado a pensar no que, do acontecimento e do sentido de acontecimento, nos é escondido de forma constitutiva, não apenas pelo pressuposto anterior, mas antes por estas dimensões do futuro que são o pro-jecto, o pro-grama, a pro-spectiva, e mesmo a pro-posição e o propósito de psicanalisar. (1989, p. 35)

\footnotetext{
${ }^{64} \mathrm{O}$ texto de Sigmund Freud ao qual Lyotard faz alusão neste escrito se refere a "Erinnern, Wiederholen und Durcharbeiten". O texto original está contido em: Gesammelte Werke, 10, p. 126,136, Frankfurt am Main: Fischer Verlag. Traduzido para o português temos: Recordar, repetir e elaborar. In: Obras completas, volume 10, São Paulo: Companhia das letras, 2010.
} 
É, portanto, no sentido de uma perlaboração, que Lyotard propõe ou ao menos sugere uma reescrita da modernidade. Isto implicaria dirigirmos nossa atenção de maneira a encontrar aquilo que não estava manifesto ou que ficou obscurecido pela força dos projetos e propósitos que tentaram se realizar, e em muitos casos com grandes esforços. Sair à busca daquilo que nos foi escondido não deverá nos trazer uma esperança redentora ou de reconciliação com uma origem traída. Muito menos podemos esperar encontrar a causa do fracasso daqueles projetos.

Este trabalho ou atividade que se coloca de maneira outra com a modernidade precisa constituir uma relação diversa com a ideia de fim ${ }^{65}$. Daí o porquê de recorrer à techné do psicanalista freudiano e a do artista do belo, como pensado por Kant. Ambas nutrem uma relação com a liberdade e não com a determinação de uma finalidade: de um lado a livre escuta, sem seleção ou julgamento, de tudo o que for relatado pelo paciente em análise, de outro o livre jogo do prazer estético que não pode ser explicado por uma determinação ou encadeamento conceitual. Deste modo, essa reescrita só pode ser um registro (p.39), nunca uma reconstituição do que no passado causou o momento presente ou causará eventos futuros, que se dará somente com o uso da livre imaginação e não de uma inferência lógica.

Esta acepção de reescrita, julga Lyotard, diz respeito à anamnese ${ }^{66}$ (p.42). Portanto, um tipo de trabalho que o autor já havia sugerido como algo que faz parte do 'curso filosófico'(1993a, p.120, 121). Este depende em larga escala daquilo que o autor chamou de leitura filosófica, leitura que deverá fornecer o essencial para a conversa que temos com nós mesmos acerca de um tema ${ }^{67}$. Deste modo, o curso filosófico se desenvolve como um ato que nada tem a ver com transmissão ou aquisição de um saber. Professor e aluno são interrogados - mesmo que não da mesma forma - por aquilo que leem. Leitura que está sempre aberta a novas releituras, que nunca se finda e sempre pode ser retomada. Entendida como uma anamnese, por ser um exercício de escuta que vai ao encontro do que pôde ainda permanecer impensado, mesmo no que muitas vezes já pensado. "Formar-se na escuta na leitura" funcionaria tal como uma elaboração, sugere o autor. Desta forma, este exercício de escuta,

\footnotetext{
${ }^{65}$ Lyotard (1990, p. 380) se preocupa em ressaltar a ambiguidade do termo fim, também presente no francês fin.

${ }^{66} \mathrm{O}$ argumento não é banal, como apresento neste momento, na verdade possui implicações de grande ordem, da qual chamaremos atenção mais adiante neste capítulo.

${ }^{67}$ Esta "conversa que temos com nós próprios" é retomada como nossa região "inumana" no prefácio de "O Inumano" e também em outros textos. Esta conversa, nesta carta, passa pelo que seria uma tentativa de "reatar com essa estação da infância" (p. 120). Tal relação que encontramos entre 'conversa interna', infância e aprender será discutida com maior ênfase mais adiante.
} 
que trabalha de forma a desconcertar as estruturas e sentidos de um texto, será também um exercício de paciência ${ }^{68}$.

A mesma anamnese da psicanálise, que serve de modelo ao paciente trabalho de exercício da escuta dos dizeres e manifestações dos alunos, em um 'curso filosófico' ou em uma aula de Filosofia, atua também no esforço de reescrever a modernidade no intento de coletar e registrar o que passou despercebido e obscurecido pelos grandes projetos e seus meios de legitimação. Entender de que forma estes elementos registrados marcaram e que talvez permaneçam a marcar o nosso pensar e agir ou, até mesmo, entender sua relação com aqueles projetos é algo que esta reescrita viria a realizar. Claro que proceder desta forma não implica encerrar a modernidade em um ciclo, para iniciar um outro. Se a reescrita pode ser considerada uma atitude pós-moderna, é muito mais pelo motivo de que a dita pósmodernidade tenta reescrever "alguns traços reivindicados pela modernidade (p.42)". Lembremos que situar os acontecimentos em uma ordem diacrônica, e também de importância, assim como assinalar o fim ou início de algum ciclo é uma operação tipicamente moderna. Uma vez que "a temporalidade moderna comporta em si o impulso para se exceder num estado que não é seu" pode-se mesmo inferir que "a modernidade está grávida do seu pós-modernismo (p.34)"

A modernidade não é retomada, nem repensada como objeto do conhecimento para esclarecer o nosso momento presente. Também não é simplesmente relembrada, se isso for o mesmo que repeti-la ou atualizá-la. Ela é reescrita.

O que vem a ser esta escrita que se volta para si em uma reescrita? Recorro agora ao modo como Lyotard se refere ao trabalho de escrita no texto "Mensagem a propósito do curso filosófico ${ }^{69}$ ":

Esta singularidade do curso de Filosofia, quero dizer: neste curso, e que lhe marca o curso, é a mesma que marca o curso filosófico. Quero dizer: escrever um texto filosófico, sozinho à mesa de trabalho (ou a andar...), leva exactamente ao mesmo paradoxo. Escreve-se antes de saber o que há a dizer e como, e para o saber, se possível. A escrita filosófica está adiantada em relação àquilo que deveria ser. Como uma criança, é prematura, inconsistente. Recomeçamos, não é fiável para chegar ao próprio pensamento, aí, ao fim. Mas o pensamento está aqui, emaranhado

\footnotetext{
${ }^{68}$ Conforme já foi discutido no capítulo anterior, a partir da forma que as reflexões de Favaretto e Fabbrini sobre o ensino de filosofia se referenciam no "exercício de escuta" proposto por Lyotard.

${ }^{69}$ Conforme o que foi indicado/sugerido na introdução as principais questões que tento discutir neste trabalho surgiram deste texto ao qual me refiro. Por este motivo (talvez não somente) é que confiarei nele o papel de um guia condutor através dos temas da filosofia de Lyotard que podem ser relacionados à educação e ao ensino de filosofia. A investigação e a pesquisa sobre estes temas mostraram que através do modo como se encadeiam algumas das questões deste texto, é possível elaborar conexões ou ligações entre estes temas que possam colaborar para possíveis esboços de respostas para as questões que este trabalho coloca.
} 
em não pensamento, tentando desemaranhar a língua perdida da infância (1993a, p.122,123)

O trabalho da escrita é esse próprio esforço do pensamento por desemaranhar-se do não pensamento, um esforço ou mesmo uma luta para dizer o que não se sabe ainda dizer. Por isso, a escrita se adianta. Ela se inicia sem saber o que há a dizer, mas para sabê-lo é que se coloca em tal curso. Somente o transcorrer desta escrita o dirá o que pode ser dito e a forma como pode ser dito. Tais coisas não podem ser antevistas antes da escrita se iniciar. Podem até ser pensadas, mas não projetadas.

De que forma, esta escrita se converte em reescrita, no caso da modernidade? Qual afinidade ela tem com o trabalho da anamnese? A escrita se inicia sem um projeto $^{70}$, sem finalidades prévias, com poucos ou nenhum indício sobre como proceder de acordo com cada contingência. Se comparado com o trabalho da anamnese já descrito, ou com o exercício de escuta que procura no texto algo de impensado, e portanto não indicado previamente, a escrita também não escolhe ou projeta aquilo que lhe convir, somente elabora para tentar descobrir o que dizer e como dizer. O que se procura - podemos inferir a partir destas reflexões do autor é a busca de que algo se torne inteligível. O que antes não poderia ser dito, agora o pode e ainda pode ser expresso para outros; o que era imperceptível agora passa a ter sua presença notada; o que antes não era pensado, pois não encontrávamos forma possível para pensá-lo, passa a ser possível de ser pensado.

Cada uma destas modalidades de 'exercício' - todas seguindo de alguma forma o modelo da anmnese - possibilitam encontrar não "a diferença" ou "a alteridade"71, mas algo que é chamado a tomar forma, algo que não encontrava expressão possível. Algo que não poderia ser detectado, percebido ou esperado, seja pela falta de uma linguagem ou idioma adequado ou quaisquer outras condições que de alguma forma atrapalham nossa percepção desses elementos.

\footnotetext{
${ }^{70}$ Lyotard (1989, p.35) ressalta como os termos, que compartilham do mesmo prefixo: projeto, programa ou prospectiva, contém em si dimensões do futuro.

${ }^{71}$ Acerca deste ponto considero oportuna a citação de um breve texto, contido na coletânea "Moralidades pósmodernas" em que Lyotard (1996, p.13, 14), opta pela forma satírica. O texto é narrado em primeira pessoa pela professora universitária francesa Marie, convidada para conferências no Japão. Na passagem ela reflete sobre seu papel no mercado contemporâneo e a experiência que vive naquele momento: "Estou satisfeita com minha conferência. Eles não vão entender nada. É lacônica demais. E escrita demais. Parece Maurice. "Francês" demais. Ou irlandês. Tende ao minimalista. Eles querem bons fluxos límpidos. Explicar de onde isso vem, para onde vai. Uma introduçãozinha. Situa-se o ponto no contexto. Ernst defendeu isso. Dick objetou aquilo, Ruth explicou que o problema está mal colocado: abordagem falocrática. E Ron, que todo mundo continua pensando de modo ocidental, enquanto existem os outros. Ah, os outros! Eles só falam disso. A diferença, a alteridade, o multiculturalismo. É a mania deles. (...) Toda essa especulação cultural, os colóquios, as entrevistas, os seminários, por quê? Só para garantir que todos falem da mesma coisa. Do quê então? Da alteridade. Unanimidade sobre o princípio de que a unanimidade é suspeita.”
} 
Mas os desafios da escritura vão além do que foi apontado. Aquilo que ainda há de ser dito, de maneira ainda não descoberta, já possui um destinatário determinado?

\begin{abstract}
Existe, portanto, na obra de escritura e de pensamento, uma indeterminação pragmática ou de destinação. O destinador, escritor, pensador, não sabe e não soube a quem ou a que se dirige o que escreve. Só soube uma coisa, formulada pragmaticamente, é que ele devia escrever e pensar como fez. Também sabe que a obra realizada não está à altura desse dever. Permanece em dívida. O destinatário indeterminado que lhe encomendou a obra permanece insatisfeito com o que lhe é entregue e o autor permanece seu devedor. É assim que ele permanece, ao mesmo tempo, devedor de todos os seus destinatários ulteriores, leitores, críticos, comentadores que, tentando propor escutas da obra, colocam-se no lugar de seu destinatário possível. (LYOTARD, 1996, p.131,132)
\end{abstract}

A escritura é marcada por uma indeterminação ainda mais ampla que atinge a dimensão do destinatário. A obra desta escritura, e também do pensamento, permitirá escutas de seus possíveis destinatários. Mas nada se sabe sobre a maneira como isso se dará. Para além da descoberta do 'que' e do 'como' no curso da escritura, os possíveis destinatários e suas possíveis escutas se darão na interlocução entre destinador (remetente) e destinatário.

Nem sempre o autor ou remetente de uma escritura ou pensamento dirá o que julga que tem a dizer de forma a receber a escuta que acredita ser adequada por parte de um destinatário. Entre as escutas possíveis, o autor provavelmente tem em mente uma que espera que seja a mais adequada em relação a outras. Se isto é provavelmente verdadeiro quando temos em vista um pensamento que tenha como referente algo sujeito à averiguação no gênero cognitivo, o mesmo não pode ser dito se situamos o trabalho de escritura no campo estético. Ou seja, nesta interlocução, ou melhor, no jogo ${ }^{72}$ entre escritura e escuta, cada parte joga com os mesmos critérios ou regras? Cabe a alguma das partes, dizer quais regras são válidas ou pertinentes e quais não são ${ }^{73}$

Desta forma, percebemos que é possível que cada uma destas partes esteja a jogar com regras distintas e que estas sejam irredutíveis umas às outras, seja por vontade das partes, seja pela característica intrínseca dos jogos e das regras. Ou, também pode ser o caso, se uma das partes pergunta a outra sobre a natureza do jogo e como se faz para jogar e nada obtém como resposta da outra parte.

Acho que o razoável é tentar aprender o jogo do outro. (...) Este (o escritor) tenta aprender a arranjar as palavras e as frases como presume que seu "interlocutor"

$72 \mathrm{O}$ uso do termo 'jogo' vem da apropriação que Lyotard faz dos 'jogos de linguagem' formulados por Wittgenstein.

73 Aqui já trazemos indícios da ocorrência daquilo que Lyotard chama de diferendo. Noção que será discutida ainda neste capítulo. Conferir também notas 29, 31 e 32 do capítulo 2. 
mudo as arranja. Isso se chama escrever, e eu diria o mesmo do pensamento. Se algo de novo surge como o acontecimento de uma obra no pensamento e na escritura, só pode ser nessa desordem pragmática (p.136)

O surgimento de algo imprevisto, no caso a obra de um pensamento ou de uma escritura é entendida como um acontecimento que só pode irromper no contexto de uma desordem pragmática que é caracterizada por este arranjo de palavras e frases forjado de acordo com o que imagina que seja o arranjo de seu interlocutor. No entanto, se esta é a postura desejada por Lyotard, outras também são possíveis. Se meu interlocutor se recusa a jogar com as mesmas regras de meu jogo, permanecendo impávido em seu jogar, eu ainda posso me retirar e sair à procura de outro que aceite as minhas regras, “(...) e isso é uma violência ao acontecimento e ao desconhecido, de maneira que você cessará de escrever ou de pensar (...) (p.137)".

Se a recusa ao aprender e a entender as regras não expressas ou explicadas pelo seu parceiro silencioso é uma violência ao acontecimento e ao que não conhecemos e não podemos prever, Lyotard nos lembra que também há algo de violento no ato de pensar e também de aprender:

(...) ou então você irá violentar a si mesmo para tentar aprender os movimentos que seu parceiro silencioso impõe às bolas, isto é, às palavras e às frases que você ignora. Isso se chama a violência de aprender a pensar ou a escrever que está contida em qualquer educação. (p.137)

A ideia de acontecimento, que é recorrente nos textos do autor, aqui é apresentada de forma conexa ao que seria desconhecido. A postura daquele que recusa o trabalho de pensamento que implica tentar aprender um jogo cujas regras não são expostas ou demonstradas é colocada como um impedimento ao acontecimento. Assim, só há abertura para o acontecimento quando há possibilidade para o imprevisto e o impensado.

Do que foi discutido nas passagens anteriores, podemos entender que o acontecimento poderia ser tratado como algo que escapa de nossos modelos de compreensão usuais. Isto seria o mesmo que dizer que somente a partir do acontecimento podemos atingir novos modos de compreensão novas linguagens, novas formas, novos idiomas?

A ideia ou noção de acontecimento não é apresentada de forma explícita, tampouco Lyotard formula uma teoria geral sobre o que seria um acontecimento (SIM, 2011, p. 70) ${ }^{74}$.

\footnotetext{
${ }^{74}$ A formulação é de Anthony Gritten no vocábulo 'Event' do Lyotard Dictionary.
} 
Mas há uma sugestão, que se aproxima bastante do que seria o seu significado no texto "Glosa sobre a resistência ${ }^{75}$ ".

(...) O que faz um acontecimento do encontro de uma palavra, de um cheiro, de um lugar, de um livro, de um rosto, não é a sua novidade comparada com outros acontecimentos. É o ter valor de iniciação em si mesmo. Só mais tarde se sabe disso. Abriu uma ferida na sensibilidade. Sabe-se, porque a partir daí ela se reabriu, e voltará a abrir-se, marcando o compasso de uma temporalidade secreta, talvez despercebida. Esta ferida fez entrar num mundo desconhecido, mas sem nunca o dar a conhecer. A iniciação não inicia a nada, começa (1993a, p.110).

Se nossa sensibilidade usual está habituada a acolher o que acontece de determinadas formas, o acontecimento marca uma ruptura com estas formas, inaugurando uma nova maneira de perceber ou sentir algo que só pode passar a ser percebido ou sentido pelo fato de que este acontecimento exige uma nova forma, uma nova linguagem ou idioma. Ela não inicia um novo tempo de fato, mas irrompe um novo registro de temporalidade que irá passar a marcar o que vier a acontecer a partir do modo como o acontecimento abriu esta ferida na sensibilidade. Enquanto a ferida ainda estiver aberta ou se reabrir, podemos entender que nossa sensibilidade continua aguçada pela irrupção daquele acontecimento.

No entanto, a ferida pode não permanecer aberta, pode haver esforços pela sua cicatrização: "luta-se contra a cicatrização do acontecimento, contra sua classificação sob a rubrica de 'criancices', para preservar a iniciação (p.110)." O que Lyotard pensa que pode ser mobilizado nesta luta é a escrita ou escritura com sua contingência incontrolável. É justamente a escritura com seu caráter prematuro que tenta se adiantar àquilo que ainda não é, que mantém viva a expectativa de manter a ferida aberta ou reabri-la. Se esse movimento incerto e incontingente da escritura - que como vimos é inspirada no modelo da anamnese for logo catalogado sob uma rubrica qualquer, ou taxado de 'criancice', ela não poderá expressar algo que antes não poderia ser dito e o acontecimento será impedido. Ou seja, é classificada de antemão em uma categoria predeterminada, escamoteando o que pode vir a ser sua singularidade e seu valor de iniciação.

Assim, se a linguagem ainda for capaz de mobilizar seus poderes de representação, criando novos idiomas para expressar o que antes não podia ser expresso, o acontecimento ainda é possível. Para Lyotard, a novilíngua orwelliana coloca em risco a sorte do acontecimento. Se for bem sucedida, transforma a linguagem em algo inerte, impede que algo

\footnotetext{
${ }^{75}$ Texto da coletânea "O pós-moderno explicado às crianças" em que a discussão proposta parte do texto "Le corps interposé" de Claude Lefort acerca da célebre obra "1984", de George Orwell. Assim, a escrita da qual fala Lyotard neste texto é a do personagem Winston em seu diário.
} 
seja dito para além do que já era permitido dizer, ordena a desordem pragmática que possibilita aprender e conhecer novas regras e novos jogos. Em suma, realiza o sonho do domínio burocrático de um totalitarismo.

No entanto o autor, não considera que a situação contemporânea seja a realização do quadro pintado no romance de Orwell. O que não o impede de perceber que há um parentesco entre a situação atual e o descrito na obra:

\begin{abstract}
Mas se repararmos na generalização das linguagens binárias, no apagamento da diferença entre aqui-agora e ali-então, que resulta da extensão das tele-relações, no esquecimento dos sentimentos em benefício das estratégias, concomitantes à hegemonia do comércio, concluiremos que as ameaças que pesam por conta desta situação, a nossa, sobre a escrita, sobre o amor, sobre a singularidade, são, na sua natureza profunda, parentes das que foram descritas por Orwell. (p.114)
\end{abstract}

Desta forma, existem riscos - os quais incidem sobre o trabalho da escritura ou da singularidade das diferentes expressões, linguagens e idiomas - que são propiciados pelo avanço nas técnicas, ciências e comunicações. Tais riscos guardam uma grande afinidade com os que a opressão totalitária proporciona.

Se em um caso a escrita luta para preservar a sua contingência contra a tentativa totalitária de colocar tudo o que ocorre no registro do já previsto, ela também se encontra em risco na situação contemporânea ou pós-moderna. Esta situação passa a ser cada vez mais orientada pelo princípio do desempenho ${ }^{76}$ com sua expectativa de aumento progressivo de eficácia. As consequências do predomínio deste princípio geraram uma relativa homogeneidade do pensar, do agir e das expectativas das pessoas. Estas estão quase sempre amparadas por ideias tal como a velocidade, a competitividade, o sucesso ou a realização ${ }^{77}$. A busca ou orientação generalizada por estas ideias, também implicam em uma pressa e em um imperativo por ganhar tempo. Algo que parece ir em direção contrária do que podemos entender que seja necessário para o acontecimento. $\mathrm{O}$ acolhimento ligeiro daquilo que nos escapa em um primeiro momento, com sua classificação apressada, impede que nossa sensibilidade se abra ou permita uma nova forma de recepção. O singular é diferente da novidade, do novo, - atributo de grande valor nos tempos atuais - o acontecimento propicia uma outra linguagem para expressar aquilo que antes não poderia ser dito a partir das formas vigentes. Aquilo que passa a ser chamado de novo é apenas mais um rótulo que promete algo

\footnotetext{
${ }^{76}$ Este princípio, proposto em "A condição pós-moderna" foi discutida a partir da página 8 do $2^{\circ}$ capítulo desta dissertação.

${ }^{77}$ Essas ideias estão na discussão sobre o idioma que o mundo ensina aos jovens presente no texto "Mensagem a propósito do curso filosófico". Foi feito referência a tal discussão no $2^{\circ}$ capítulo.
} 
que os anteriores não apresentavam, mas este novo será recebido sem alterar em nada nossas formas de sensibilidade (1993a, p. 110, 111).

Lyotard (1989, p.10, 11) insiste que “(...) a escritura e a leitura são vagarosas, avançam para trás, na direção da coisa desconhecida 'no interior'. Perde-se o tempo em busca do tempo perdido. A anamnese é o antípoda (...) da aceleração e da abreviação.” Somente em sua vagarosidade, pode a escritura manter a possibilidade de que o acontecimento possa vir à tona. Tal como o 'curso filosófico' exigia um trabalho paciente de escuta de maneira oposta aos valores contemporâneos orientados pelo princípio do desempenho, a escritura da mesma forma é mobilizada para combater a aceleração e a apressada categorização de tudo o que ocorre.

Mas não é somente a situação contemporânea ou um domínio burocrático que se esforça por colocar toda possibilidade de acontecimento sob seu controle (SIM, 2011, p. 72). As narrativas operam com o intuito de propor um sentido prévio ao que acontece para que esteja em concordância com o rumo e com a estrutura da narrativa. Se entendermos que o acontecimento possui caráter desordenador, a narrativa se organiza para situar as ocorrências ou as frases de um discurso na ordem que antes já era estabelecida. $\mathrm{O}$ que pode ser um modo bastante efetivo de se preservar diante da ameaça desordenadora que o acontecimento traz consigo (1988, p. 140, 141; LD 198). Ao tentar bloquear a força do acontecimento, a narrativa se empenha em manter sua estrutura intacta. Se isto pode ser dito sobre o modo como a narrativa acolhe o acontecimento, isto deve ser ainda mais restritivo se pensarmos em termos de uma metanarrativa.

Desta forma, destacamos os perigos que são lançados para a sorte do acontecimento com seu valor de iniciação. Para que ele seja possível, o trabalho de escritura é mobilizado como um motor de resistência frente às forças que tentam fazer da linguagem algo cristalizado e inerte.

Na discussão proposta por Lyotard sobre a Filosofia na sala de aula, em seu 'curso filosófico', percebemos que a ideia de resistência pode ser tomada em dois momentos distintos:

Em primeiro lugar, é necessário resistir à instauração da novilíngua. Tal resistência se dá na luta da escritura contra a cristalização da linguagem, na medida em que a anamnese é oposta à aceleração. Em segundo lugar, podemos perceber uma certa resistência dos alunos ao exercício de escuta.

Neste segundo exercício de resistência, encontramos um choque entre dois idiomas distintos, presentes na sala de aula (1993a, p.121-125): o do curso filosófico que exige a 
paciência, a demora no exercício de escuta, no reexame dos pressupostos e subentendidos de cada texto ou cada discurso; e o idioma falado pelos alunos que é justamente aquele que o mundo lhes ensina sob as marcas da velocidade, da performance, da competitividade, do sucesso entre outros. Dois idiomas sem medida comum, incomensuráveis.

Como resolver tal embate, em que a busca por um consenso entre as partes não está no horizonte? Uma vez que um não pode se medir pelo outro, quais critérios podem ser mobilizados para regular este choque?

O que existe entre o 'curso filosófico' e o idioma regido pelo princípio do desempenho, que é falado pelos alunos, é aquilo que Lyotard chama de diferendo. Esta noção é discutida na obra "Le differend", publicada em 1983, quatro anos após a "Condição pósmoderna".

Primeiramente, o diferendo é colocado de modo a se distinguir de um litígio. Neste, a discordância pode ser resolvida em um tribunal que determina quais regras são pertinentes para resolver a disputa das partes, enquanto estas devem estar de acordo com tais regras ou critérios para que o tribunal tenha legitimidade para dar fim ao litígio. Nada disto ocorre no diferendo. Este se configura (LYOTARD, 1988, p.9; LD §12) ${ }^{78}$ quando o queixoso se encontra despojado dos meios de argumentar em seu favor, tornando se assim uma vítima ${ }^{79}$, de maneira que a regulação do conflito seja feita no idioma de uma das duas partes, sendo que o prejuízo sofrido pela outra parte não tenha significância neste idioma. Assim, a vítima se encontra impossibilitada de colocar seu prejuízo em um enunciado, em um discurso que encontre significado no idioma que ocupa o lugar da regulação.

Reconhecer o diferendo, em vez de querer transformá-lo em um litígio, é tentar encontrar novos significados para as queixas da vítima, fazendo com que ela deixe de ser uma. A tentativa de dar expressão ao seu prejuízo em novas frases ou novos regimes de discursos implica em criar novos remetentes e novos destinatários, assim a vítima que não tinha a seu dispor um idioma que expressasse seu prejuízo, passa a ocupar um lugar que não poderia ocupar antes, o de remetente de enunciados e frases. Deste modo, o diferendo seria "o estado e instante instáveis da linguagem em que algo é possível de ser colocado em frases, mas ainda não pode ser" (1988, p.13; LD §21, 22,23). Por isso que o diferendo 'pede' para ser expresso em frases. Também por este motivo que o imperativo de prestar testemunho ao diferendo deve se transformar na tarefa de buscar os idiomas que hão de ser criados para que

\footnotetext{
78 De modo que usamos a tradução para a língua inglesa de "Le Differend", optamos por colocar também a numeração das seções que estão tanto na edição inglesa como na francesa.

${ }^{79}$ A situação da vítima seria explicada pela condição de não ter direito a testemunhar o dano sofrido para um público e, sobretudo para um tribunal.
} 
o prejuízo da vítima possa ao menos ganhar expressão.

Talvez seja possível afirmar que as metanarrativas que visavam emancipar a humanidade, nos fizeram acreditar ser possível transformar todo diferendo em litígio a partir de um tribunal da razão universal. Não é possível negar que uma revolução e sua mudança de regime político sejam capazes de trazer alguns diferendos a luz e dar expressão às queixas que não eram ouvidas em seus idiomas. Mas jamais poderá instituir o fim dos diferendos ou sua definitiva substituição por litígios. Não é possível postular que a linguagem pode eliminar de vez seus momentos de instabilidade.

Podemos dizer, então, que é no momento em que o diferendo é percebido que a possibilidade para o acontecimento se dá. Ou melhor, a ocasião em que há a irrupção para o acontecimento pode ser justamente a do momento entre a percepção de que um idioma sofre o prejuízo na regulação por um segundo idioma, e o surgir de um terceiro que dá expressão a esses prejuízos, de forma a não mais ocupar a mesma posição de vítima em que se encontrava antes.

De que maneira é possível entender a motivação da formulação da ideia de diferendo? Ideia que parte de uma disputa entre parceiros concebida de maneira bastante mais complexa do que a ideia de litígio. Não se trata somente da diversidade de idiomas ${ }^{80}$ ou de gêneros que são presididos por regras bastante peculiares e diversas entre si. Mais do que isso, é importante apontar que cada indivíduo é constituído por um diferendo interno e é este que podemos apontar como motor do trabalho de escritura e do pensamento (LYOTARD, 1996, p. 132, 133, 136). O jogo entre a escritura e suas possíveis escutas - apontado anteriormente não é mais do que o que ocorre quando o escritor busca o melhor idioma para expressar o que ainda não sabe e que ainda não sabe como será escutado. No trabalho de escrita - e também no do pensamento - o escritor discute consigo mesmo o que e o como irá dizer, assim como a forma que será entendido ou interpretado. Assim, o parceiro silencioso que não nos informa quais as regras do jogo que joga, também se encontra 'dentro' de nós ${ }^{81}$.

Há, portanto, antes de uma comunidade de parceiros que jogam diferentes jogos e operam diversos idiomas, algo ou um parceiro que nos povoa, que nos provoca a forjar um novo idioma ou simplesmente a pensar.

Seria possível afirmar, na linha proposta por Lyotard, que neste ser divisível em vários parceiros que somos, possuímos uma região que nos provoca e nos impele ao que ele chama

\footnotetext{
${ }^{80}$ Conferir nota 29 do capítulo 2.

81 'Em primeiro lugar, verá que ela (a pragmática) é 'interna', por assim dizer, tanto quanto externa, na medida em que cada indivíduo suposto é divisível e verossimilmente dividido em muitos parceiros - o que, em suma, Freud, pelo menos ensinou-nos há quase um século e não é razoável ignorar.” (LYOTARD, 1996, p. 132, 133)
} 
de trabalho de escritura, e que é, em suma, o mesmo que pensar e aprender?

Uma outra região ou uma existência separada para a qual Lyotard atribuiu nomes diferentes. 'Inumano ${ }^{82}$, ' 'no men's land', 'parceiro estranho'. Todas elas indicando uma região da qual ao mesmo tempo em que nos impele a não permanecer no mesmo estado, também escapa a qualquer tipo de controle, seja por iniciativa própria seja por constrangimento externo. Ao afirmar esta divisibilidade que há em cada um de nós, Lyotard propõe que antes de jogarmos com parceiros externos, temos de nos haver com este outro que é estranho e familiar ao mesmo tempo.

Em um debate em que existem posições antagônicas, é habitual entender que um pretende persuadir o outro de que tem a razão, enquanto o outro não terá. O que acontece neste debate interno? Este outro que povoa cada um pode ser colocado na posição de rival? Antes de discutir nestes termos, que partem do pressuposto de que todo jogo implica em ter um lado vencedor e outro derrotado ${ }^{83}$, talvez seja melhor equacionar a questão da seguinte forma: O que nos coloca a pensar? Se pensar é um árduo e penoso trabalho, o que nos provoca ou nos impele a pensar, escrever, criar, representar, imaginar?

Há muito partilhamos de uma tradição que concebe o pensar como uma predestinação da humanidade. Não se trata de querer somente romper com a tradição, mas repensar esta condição. Tal condição é elaborada de forma a vir acompanhada de seu duplo, daquilo que Lyotard (1990, p.10) chamou de inumano.

\begin{abstract}
Existiriam assim dois tipos de inumano. É indispensável mantê-los dissociados. A inumanidade do sistema em curso de consolidação, sob o nome de desenvolvimento (entre outros), não deve ser confundida com aquela, infinitamente secreta, de que a alma é refém. Acreditar, como aconteceu comigo, que a primeira possa substituir a última, dar-lhe expressão, é cair no engano. A consequência maior do sistema é a de fazer esquecer tudo o que lhe escapa. Mas a angústia, o estado de um espírito assombrado por um hóspede familiar e desconhecido que o agita, fá-lo delirar mas também pensar - se pretendemos exclui-lo, se não lhe damos uma saída, agravamolo. O mal-estar aumenta com esta civilização, a exclusão com a informação.
\end{abstract}

A hipótese que o autor apresenta é de que é próprio do homem, em sua humanidade, ser habitado pelo inumano. E que aquilo que ele chama aqui de desenvolvimento, e em outros momentos de princípio de desempenho, por mais que possa ser considerado como inumano, é

\footnotetext{
82 Termo que é usado como título para uma coletânea de textos e palestras (1990). As passagens aqui utilizadas provêm de seu prefácio: "Do humano".

${ }^{83}$ Pode se jogar de diversas formas afirma Lyotard (1996, p. 121), inspirado nos distintos domínios da crítica kantiana: "Digo que não se acaba com o dissentimento da mesma maneira , conforme se trate de resolver uma equação de segundo grau, de estimar a beleza de uma escultura, de explicar um fenômeno físico, de avaliar a justiça de uma ação, de escolher um voto quando de uma eleição. (...) A racionalidade só é razoável se admitir que a razão é múltipla, como Aristóteles dizia que o ser se diz multiplamente."
} 
completamente distinto deste outro inumano que nos habita. Este nos provoca, nos angustia e nos impulsiona a não permanecer os mesmos. É importante notar que não é apesar deste estado de espírito, que nos faz delirar, mas também pensar, por nos colocar em um estado de desassossego, que somos coagidos ao trabalho de pensamento. $\mathrm{O}$ ato de pensar não é algo prazeroso ou espontâneo - o que imaginam os humanistas, parece indicar Lyotard - mas que fazemos por que somos perturbados por esta outra existência.

Que poderemos chamar de humano no homem? A miséria inicial da sua infância ou a sua capacidade de adquirir uma 'segunda' natureza que, graças a língua, o torna apto a partilhar da vida comum, da consciência e da razão adultas? Num ponto estamos todos de acordo: esta última assenta e suporta a primeira. (1990, p.10)

Assim, seria por causa deste hóspede familiar e desconhecido que somos propriamente humanos. Por causa dele é que suportamos nossa miséria inicial a ponto de nos dotarmos de uma segunda natureza que nos coloca como partícipes de uma vida comum possibilitada pela linguagem e pela cultura e que leva à superação daquela etapa inicial.

Por estes motivos, é que Lyotard encontra na imagem da infância a melhor representação do que é o humano. Nada mais humano do que a criança refém da comunidade adulta. Sendo ela desprovida de palavra e incapaz de projetar seus interesses ou benefícios, estará sempre em um estado de aflição ou de hesitação. É este estado de inconstância, que permite um lento progredir da criança para munir se da linguagem, que a fará participar da comunidade adulta. De maneira próxima, o adulto é acossado por sua inumanidade a tornar se mais humano.

É devido ao inumano que o homem, adulto ou infante, pode tornar-se mais humano no sentido de estar mais avesso à inumanidade do sistema em desenvolvimento regido pelo princípio do desempenho. É somente no testemunho ou percepção dos diferendos, internos e externos, que é possível a criação de mais idiomas, assim como de novos remetentes e destinatários. O inumano, se não é bloqueado ou impedido de ganhar expressão, permite que os homens se tornem mais humanos, enquanto o desenvolvimento opera no sentido inverso, colocando em curso outro tipo de inumanidade.

É importante lembrarmos do ritmo próprio da escritura, do exercício da escuta ou mesmo da paciência que é necessária para perceber um prejuízo e forjar o idioma que o expresse. Por outro lado: “A consequência maior do sistema é a de fazer esquecer tudo o que lhe escapa". Aquilo que não é de imediato proveito, que não se encaixa nas formas preestabelecidas, ou que simplesmente resta e nos escapa, torna-se digno de suspeição e deve 
ser logo esquecido.

\begin{abstract}
Não me agrada esta pressa. O que apressa, o que esmaga, é o que acabo sempre por constatar ter tentado sob os mais diversos nomes, trabalho, figurabilidade, heterogeneidade, dissentimento, acontecimento, coisa, preservar: o inconciliável. ( E não sou o único, razão pela qual escrevo 'nós'.) Que a diferença insensível seja votada a ter sentido, enquanto oposição num sistema dito estruturalista, é uma coisa; outra é que ela seja prometida ao devir-se sistema. Como se a razão não tivesse que duvidar da sua vocação para extrair o indeterminado, dando-lhe depois forma, e que desta acção não pode deixar de sair triunfante. É contudo apenas ao preço desta dúvida que a razão é raciocinante. (1990, p.12)
\end{abstract}

Lyotard insiste que, apesar do ímpeto que a razão humana tem de a tudo buscar desvendar, algo permanece resistente a tais investidas. Entre a confiança e a dúvida desta vocação de extrair o indeterminado é que parece situar-se também nossa região inumana. A confiança nos poderes de nossa razão em se expandir depende em muito da dúvida que a mesma nutre sobre tais poderes. Assim, há sempre algo de inconciliável nos esforços de determinação de nossa razão. Nossa humanidade caminha entre nossa indeterminação nativa e a razão que quer se instituir. O que nos leva a afirmar que o acontecimento, com sua abertura para os possíveis, não poderá ser de todo bloqueado, por mais que o sistema em desenvolvimento opere neste sentido.

A ideia de escritura, usada pelo autor com frequência, pode ser entendida de uma forma mais ampla do que simplesmente o ato de escrever, uma vez que é associada ao ato de pensar. Devemos passar a entender a escritura como o processo de elaboração do pensar. Que é sempre prematuro e hesitante em relação ao que tenta se tornar.

(...) Escreve-se antes de saber o que há a dizer e como, e para o saber, se possível. A escrita filosófica está adiantada em relação àquilo que deveria ser. Como uma criança, é prematura e inconsistente. Recomeçamos, não é fiável para chegar ao próprio pensamento, aí, ao fim. Mas o pensamento está aqui emaranhado em não pensamento, tentando desemaranhar a língua perdida da infância. (LYOTARD, 1993a, p.122, 123)

Toda escritura ou todo pensar precisa se haver com sua prematuridade. Em seu curso, hesita e se adianta rumo ao que ainda não sabe dizer, escrever ou pensar. O pensamento, neste sentido, parece nunca abandonar a estação de sua infância de fato.

Se é na escritura - ou como discutíamos antes, no jogo estre escritura e escuta - que encontramos conjugados o pensamento e a infância, talvez esteja aqui o ponto privilegiado em que a filosofia de Lyotard apresenta pontos de contato com a discussão educacional. 
Ao passo em que somos habitados por uma segunda existência, somos impelidos neste movimento hesitante a colocarmo-nos no rumo de descobrir as expressões e idiomas possíveis daquilo que ainda nem sabemos que temos a dizer. Assim também é a criança tomada refém do mundo adulto, assim é o trabalho do escritor que não sabe como sua obra será acolhida.

O aprendizado que a educação visa, poderá recorrer a esta mesma imagem? No jogo com aquele parceiro estranho, que segue em seu jogo sem elucidar suas regras, hesitamos em tentar imitar seus lances para jogar junto, inseguros se jogamos da maneira apropriada ou não. Sabemos que o jogo pode caminhar ou não para o aprendizado das regras criadas pelo nosso parceiro silencioso, ou que em cada um dos lances, de ambos os lados, deem origem a um novo jogo. Mas o que interessa é que não há predisposição natural ou imediata que faça com que este jogo seja assimilado pela parte que antes o desconhecia. Isso se dará com o esforço e com a violência que é exercida sobre si próprio para se forçar a aprender algo que ainda não conhece. É isto que Lyotard (1996, p. 137) chama de "violência de aprender a pensar ou a escrever que está contida em qualquer educação".

Percebe-se que a educação é entendida aqui não como consequência de uma coerção externa para a conformação ou assimilação de regras, mas como um processo interno que é o de coagir-se a si próprio, entendido como necessário para qualquer aprendizagem.

Sem a existência e o contato com este parceiro estranho, que nada mais é do que o que Lyotard chama de inumano, não podemos entender o que é o humano e sua peculiaridade de transitar de sua miséria inicial a uma razão instituída. Não pode haver formação do homem mesmo preservando as múltiplas facetas e significados do termo - sem essa separação interna que dá contornos a região inumana.

Assim, toda educação pode ser entendida como inumana, infere Lyotard (1990, p, 12)

(...) Toda educação é inumana visto que não funciona sem contrariedades e terror, e refiro-me à menos controlada, menos pedagógica, aquela que Freud chama de castradora e o que faz dizer a propósito de 'boa maneira' de educar as crianças, que de qualquer forma será má (nisto próxima à melancolia kantiana). E inversamente, tudo o que no instituído pode, por vezes, deixar transparecer o infortúnio e a indeterminação é de tal maneira ameaçador que o espírito razoável não pode deixar de temer justificadamente, uma força inumana de desregulação.

Sabemos que as crianças não são todas puras e programadas pela natureza. Caso os humanos nascessem tal como os gatos nascem gatos, não haveria necessidade de educar as crianças. Por isto que este processo de progredir ou de humanização, uma vez que não é somente fruto do curso da natureza, implicará de alguma forma em contrariedades ou 
até mesmo em momentos de terror, em que o educando é impelido a trilhar um caminho que não sabe qual será e a que levará.

Por estes motivos é que a educação, mais ou menos controlada, será má, pois implica uma violência, ainda que interna. Quando o educando já está melhor inserido no mundo da linguagem e da cultura - pensemos nos nossos alunos de Ensino Médio ou naqueles jovens que Lyotard afirma falarem o idioma do desempenho, ensinado pelo mundo não há violência ou coerção que o faça aprender coisa qualquer. Só ele pode, por decisão mais ou menos voluntária, forçar-se e violentar-se, tentanto entender e fazer uso de regras de outros jogos que ele não domina.

Desta forma Lyotard recusa uma ideia de aprendizagem ligada ao prazer ou a uma conciliação com uma natureza intima que, uma vez restabelecida, inibiria os conflitos inerentes ao ato educacional. Parece ser isto que Lyotard (1993b, p.51) chama de 'pedagogismo'.

(...) Há actualmente nos estabelecimentos de ensino jovens que não estão lá a fazer nada. Estão lá porque é obrigatório, exatamente como no quartel. Tal como os recrutas, procuram sobretudo iludir os meios da instituição, pelo que parecem estranhos ao fim desta, que é os de os instruir. Parecem antes querer gozar o que está imediatamente disponível. O "pedagogismo" concede-lhes isso. Ele contribui para o fracasso da escola. (...)

Esta ideia de pedagogismo é apresentada como a saída fácil para os estudantes que estranham o ato de instrução e jogam para escapar ou evitar seus procedimentos, que carregam os traços dos quais citamos acima. Lançar mão do pedagogismo é ceder aos anseios de que a tarefa educativa deva se pautar pelo prazer ou pela amenidade, o que parece ser bastante avesso ao modo como Lyotard concebe a aprendizagem.

Isto pode ser confirmado em mais um momento (p.52) em que o termo pedagogismo é usado:

O 'pedagogismo' é um exemplo de aplicação infeliz da democracia à escola. Ele supõe que todas as opiniões são boas, que é saudável que as pessoas se exprimam. Que erro! Isso não faz bem a ninguém e enfada toda a gente porque as suas opiniões são, na maior parte dos casos, preconceitos. Os filósofos desde sempre nos disseram que o diálogo não é a troca de opiniões. É um exercício terrivelmente rigoroso e constrangedor.

Sabemos como uma aula de Filosofia, entre outras, pode apresentar uma ilusória benevolência no acolhimento à fala do outro. Nada mais enfadonho, aponta Lyotard, de maneira certeira. Não se trata de restringir a fala do aluno em sua imaturidade, mas que o 
direito a toda e qualquer opinião não pode ser tomada como princípio democrático. No capítulo anterior falávamos de como a sala de aula guarda semelhanças com a ágora, lugar onde tudo pode ser dito e onde se pode ainda amar as discussões. Mas somente na medida em que não se prejudique o rigor que a reflexão deve preservar, e que não se esqueça que o exercício do pensamento se dá em ritmo próprio, e que o opinar a todo custo, geralmente de maneira apressada e atabalhoada, parece estar muito mais próximo dos valores que regem o desenvolvimento e o desempenho. A prematuridade e hesitação infantis são marcas constitutivas do trabalho de pensamento, e que correm grandes riscos de serem refreadas no estímulo descuidado ao opinar apressado que o pedagogismo alimenta.

Parece ter ficado bastante claro que a ideia de pedagogismo é uma má resposta, seja para o suposto fracasso dos ideais formativos modernos, seja para o diferendo entre o curso filosófico e o idioma falado pelos alunos. Claro está também que um abandono completo de tudo que estava implicado no ideal de formação não resultaria em uma forma de exercício pedagógico qualitativamente superior. Assim como os pressupostos presentes no curso filosófico não respondem àquilo que os jovens habitualmente demandam. O que nos leva a investigar qual grau de semelhança podemos encontrar entre o ideal de formação moderno e o curso filosófico proposto por Lyotard.

A primeira coisa a ser comparada são seus fins. O ideal de formação visa à emancipação do educando ao cabo de um processo, assim vislumbrando que se trata de um processo que alcançaria seu esgotamento atingindo sua completude. Neste ponto o curso filosófico diverge em grau suficiente, pois seu curso não tem fim ${ }^{84}$, está sempre no meio, 'em curso', sempre disposto ao recomeço (1993a, p. 120). Não há fim em um processo, que pode sempre recomeçar, que nunca se exime de buscar o impensado no já tantas vezes pensado e que precisa buscar os outros possíveis do pensamento, mas que não puderam vir à tona.

Ainda assim, é possível encontrar semelhanças entre os dois registros. Ambos encerram uma relação com o transcorrer do tempo ${ }^{85}$. Discutimos no capítulo anterior, a partir da apropriação que Favaretto faz de Lyotard, a forma como tais propostas de ensino de Filosofia, ou do curso filosófico, conservam em certa medida a relação que a imagem tradicional de formação carrega consigo. Nesta, temos um processo que transcorre em tempo próprio, preparando o jovem emancipado para a vida pública. No curso filosófico a relação que se tem com o tempo também é pautada pelas suas próprias exigências. Em ambos os casos há uma suspensão do tempo, ou o seu temporário esquecimento. Deixam-se de lado as

\footnotetext{
${ }^{84}$ Lembremos da ambiguidade do termo fim, comentado na nota 65 deste capítulo.

${ }^{85}$ Conforme já discutíamos no capítulo anterior.
} 
exigências do mundo para aguardar o seu lento progredir. No capítulo anterior, aventei a possibilidade de que o curso filosófico extrapola a relação que o ideal de formação nutre com o tempo. Não somente o coloca em suspensão, mas dispensa de certa forma seus fins. O faz por não acreditar que a emancipação do estudante se dê pela capacidade de encontrar uma unidade de experiência, pois pressupõe a heterogeneidade dos conhecimentos e técnicas que exigirão respostas e condutas diferentes. Não há unidade no mundo contemporâneo.

Ainda que tais diferenças sejam bastante marcantes e significativas, ambas tentam fazer frente a intentos claramente reativos. Se a emancipação concebida pelos modernos se encontra interditada, quando pensada naquela chave, é preciso estar suficientemente atento para os contornos que a situação contemporânea apresenta, para que qualquer tipo de emancipação ou exercício de resistência ${ }^{86}$ seja inviabilizado.

Ora, o curso filosófico não projeta um fim tal como o faz o ideal de formação para a emancipação. Disto não se pode inferir que tarefas não possam ser colocadas, ou que não há nada para se realizar, seja no campo educacional ou em outros.

(...) E assim se circunscreve uma tarefa decisiva: tornar a humanidade apta a adaptar-se a meios de sentir, de compreender e de fazer muito complexos que excedem o que a humanidade procura. Essa tarefa implica no mínimo a resistência aos simplismos, às palavras de ordem simplificadoras, aos pedidos de clareza e facilidade, aos desejos de restaurar valores seguros. Já se torna visível que a simplificação é bárbara, reactiva. (LYOTARD, 1993a, p. 103, 104)

Há perigos a serem evitados. Se não podemos mais projetar fins para a ação educacional como antes, isto não implica em nos eximir de responsabilidades. Insistir na recusa aos 'pedagogismos' e também das frágeis tentativas de reconciliação e de restauração de valores seguros é algo urgente e que deve ser tomado como tarefa por quem se situa no campo da educação. Reunir estas perigosas propostas sob a rubrica de 'simplismos' resume bem o imperativo pela complexidade, a qual Lyotard (1993b, p.50) sugere como estratégia razoável para os impasses que permeiam a ação educacional no cenário pós-moderno:

Nesta perspectiva, se eu devesse atribuir uma finalidade à educação - é uma pura hipótese da minha parte, - seria a de tornar as pessoas mais sensíveis às diferenças, de fazê-las sair do pensamento massificante. É preciso educar, instruir, nutrir o espírito de discernimento, formar para a complexidade.

${ }^{86}$ É notável a forma como o termo resistência é cada vez mais utilizada pelos autores da segunda metade do século XX, enquanto o termo emancipação parece rarear. 
Não contramão dos simplismos, que podem até levar à barbárie, a educação deve trabalhar para que estejamos mais aptos a discernir as situações que se apresentam em formas mais e mais complexas. A mesma sensibilidade que o acontecimento exige é evocada aqui mais uma vez como antídoto ao pensamento massificante. A humanidade não encontrará uma chave única e mágica para seus problemas, tampouco a educação formal a ensinará ou a legará aos jovens. Mas, se nossos esforços educacionais ainda puderem se dirigir para o melhor discernimento das múltiplas situações que exigem novos olhares, idiomas diferentes para problemas diferentes, o pior ainda poderá ser evitado. Alguma resistência pode encontrar espaço, e o acontecimento não se dará por bloqueado de maneira definitiva.

Então temos a hipótese de que tarefas ainda podem ser concebidas e até mesmo finalidades - não na forma de projetos que orientem nossa ação de maneira unitária e coesa podem ser imaginadas para fazer frente à barbárie ou às piores formas de reacionarismo. Como podemos imaginar o escopo de ação do professor de Filosofia?

Lyotard nos oferece uma comparação, da qual podemos fazer uso para esboçar uma resposta. Em "Le Differend", o autor discute as diferentes responsabilidades do filósofo e do intelectual. O papel do filósofo é de detectar diferendos - os quais podem estar mascarados sob outras formas - e encontrar o idioma para expressá-los. O intelectual, por sua vez, irá advogar por um certo gênero de discurso a ponto de conquistar hegemonia frente aos outros gêneros, o que leva a esquecer ou obscurecer diferendos.

Se o esforço do intelectual for bem sucedido, uma consequência possível é a maior recorrência de vítimas. Se há um gênero hegemônico, muitos apelos podem ser reduzidos ao silêncio e a linguagem vai perdendo gradativamente sua inconstância e sua desordem que a permite ser sempre reorganizada, repensada e rearticulada. Diferendos não mais serão reconhecidos, as portas para o acontecimento estarão prestes a se cerrar e a novilíngua - se levarmos tal situação ao extremo - pronta para se instaurar.

O que isto nos indica sobre o trabalho do professor de Filosofia em suas aulas? Quais diferendos pode ele detectar? Parece claro que seu ofício passa a ser o de exercitar, no seu trabalho constante com a linguagem, uma outra sensibilidade a lidar com as coisas não da maneira simplificadora da qual falávamos. Ele não pode chegar para suas aulas encerrado sob um idioma único que responderá a todos os problemas e questões. Sejam quais forem os diferendos, idiomas ainda não criados, ou queixas existentes, se o paciente exercício de escuta não for propício para dar-lhes expressão, a experiência de pensamento que o curso de Filosofia ensaia de pouco servirá. 


\section{Considerações Finais}

Procurarei neste momento final da dissertação tecer algumas considerações acerca das questões, discussões e apontamentos que surgiram por ocasião da investigação aqui feita. Ao tentar investigar sobre as relações possíveis entre o ideal de formação e o ensino de Filosofia que se tornou obrigatório no Ensino Médio brasileiro, percebemos as mais variadas formas de interrogar não somente o ensino de Filosofia como objeto específico, mas também a diversidade de maneiras em que tal relação pode ser expressa, pensada e discutida. Relação que pensamos ser de importância máxima estabelecer e discutir, se quisermos pensar na presença da Filosofia no Ensino Médio. No entanto, tal relação nem sempre é discutida, e por vezes aparece pouco explicitada em alguns estudos, pelos mais diversos motivos.

Sendo muitos os caminhos para discutir o ensino de Filosofia, elencamos como fio condutor a sua relação com o ideal de formação e a forma que tal relação toma na contemporaneidade ou na pós-modernidade. Na tentativa de encaminhar este intento, este trabalho acabou por se ocupar de uma gama de variados assuntos os quais, por vezes, se afastavam em certa medida da temática do ensino de Filosofia ou não apresentavam relação direta com ele. Assim, tal temática teve discussão privilegiada no terceiro capítulo desta dissertação. Assim, se muito do que foi discutido nos demais capítulos se afastou em alguma medida dos assuntos educacionais e também do ensino de Filosofia, tentarei reaproximá-los daquelas discussões neste espaço.

De maneira um pouco arriscada pretendo ir ainda um pouco mais além das discussões presentes nesta dissertação, para confrontá-las com a experiência do ensino de Filosofia que é ministrada hoje nas escolas. Não me interessa aqui discutir que formas ele toma ou que metodologias são utilizadas, ou quais escolhas temáticas são feitas. Creio ser de um interesse maior destacar o que é possível atentar no que permeia o imaginário dos alunos e na forma como eles mobilizam o seu pensamento para os temas de uma aula de Filosofia, e também para o da realidade que podem perceber a sua volta ${ }^{87}$.

Sendo que o termo formação não é de todo inequívoco, podendo suscitar diversos entendimentos - e o mesmo pode ser dito para a expressão 'ideal de formação ${ }^{88}$ ' -

\footnotetext{
87 Para isso, nenhuma pesquisa empírica foi feita. Portanto, não imagino que o que for apresentado aqui tenha valor suficiente para algum tipo de orientação mais sistematizada para planos de ensino ou qualquer tipo de diretriz para políticas públicas. Parto somente de experiências pessoais em sala de aula e impressões colhidas no cotidiano escolar com os seus mais diversos atores. Experiências e impressões que não podem ser generalizadas para uma maior amplitude de casos, mas que uma vez confrontadas com a discussão teórica aqui feita, podem apontar para questões interessantes.

${ }^{88}$ Em alguns momentos a expressão utilizada foi 'ideia de formação'.
} 
concebemos o primeiro capítulo para melhor delimitar o tema e explicitar suas principais características. A opção foi por tentar esboçar um quadro de características que podem ser encontradas quando falamos de formação ou no termo alemão Bildung. Para tanto, também examinamos a noção de Bildungsroman.

Ainda que os traços que compõem o quadro tenham todos a sua relevância, foi possível eleger alguns e a eles dar maior importância, sobretudo se visamos discutir dentro do campo da educação. Uma vez que os anseios da Bildung pareciam estar muito próximos daqueles do movimento do Iluminismo, a emancipação e a autonomia se mostraram como traços a serem destacados. Assim, estes traços parecem ter sido legados à tarefa educacional por força da vinculação do ideal de formação com o Iluminismo ${ }^{89}$. Não à toa, escolhemos como fio condutor inicial desta discussão o texto de Kant "Resposta à pergunta: O que é o esclarecimento".

Ainda que a importância de tais traços tenha que ser destacada, há uma outra que se mostrou fundamental para pensarmos sobre o alcance do ideal de formação na contemporaneidade $^{90}$. Falo do tempo em que se dá a formação em seu processo. Principalmente ao fazermos recurso ao romance de formação, percebemos que é apenas lentamente que o personagem se forma e de uma maneira que pode chegar a ser totalmente imperceptível.

Para além deste intento, examinamos três textos ${ }^{91}$ que penso serem estratégicos para melhor entender a noção de Bildung. Nestes, identifico um traço comum que é um jogo entre potências antagônicas que, de alguma forma, entram em ação em um processo que pode ser considerado formativo. De modo breve, tento resumir quais seriam estas potências para cada autor: em Kant, um princípio social se digladia com um antissocial; para Schiller há várias oposições e a que parece fundamental, e até pressupor as demais, é a oposição entre os impulsos formal e sensível; finalmente em Nietzsche, os impulsos fundamentais da arte grega: o apolíneo e o dionisíaco.

\footnotetext{
${ }^{89}$ É o que parece apontar Lyotard (1993a, p. 123) em passagens como: “(...) A modernidade, as luzes, a própria reflexão kantiana colocaram a escola no centro do interesse popular e prático da razão. Desde há dois séculos, principalmente em França, e também de outro modo na Alemanha, o objetivo desse interesse chamou-se formação do cidadão na república. A tarefa filosófica viu se confundida com a da emancipação".

90 No $3^{\circ}$ capítulo, retomamos a questão da formação e do tempo no qual ela transcorre. Ali, destaco o uso que Favaretto faz da expressão "imagem tradicional de formação". Uma imagem que pressupõe que a formação não se dá somente no transcorrer do tempo mas também visando um fim, um telos. Voltaremos a tal ponto, mais adiante.

91 Conforme discutido no $1^{\circ}$ capítulo, falo dos textos "Ideia de uma história universal de um ponto de vista cosmopolita" de Immanuel Kant. "A educação estética do homem" de Friedrich Schiller e o "Nascimento da tragédia" de Friedrich Nietzsche.
} 
Naquele capítulo lancei uma suspeita ou hipótese sobre a formação. A de que a Bildung moderna traz consigo tanto a ideia de conservação quanto a de transgressão ou de singularização. Ao chamar atenção para a forma como aquelas potências ou impulsos eram apresentados naqueles diferentes escritos, uma questão há de ser colocada: cada uma das oposições pode ser classificada, em alguma medida, de modo a serem associadas a cada um destes dois princípios?

Examinemos mais de perto. Em Kant, a associação parece ser mais fácil se tivermos em vista que o que é objeto de discussão é a propensão da natureza humana à sociabilidade humana, contenda que tem como ponto fundamental a Política de Aristóteles e foi tantas vezes debatida pela filosofia política moderna, como sabemos.

$\mathrm{O}$ princípio que chama o homem à socialização, caso estivesse isolado do outro princípio, o colocaria em permanente estado de indolência e concórdia com os demais, conservando-se nesse estado. Mas aquilo que Kant chama de princípio antissocial é que impede essa permanência. Se não se trata de um ímpeto ou chamado à transgressão de uma dada ordem estabelecida, ele é ao menos uma propensão para colocar a vontade própria à revelia das demais, delas se apartando e se singularizando.

Em Schiller, a aproximação requer maiores cuidados. Para o autor, há exigências que são feitas por cada um dos impulsos. Lembremos que o impulso sensível só trata de casos, enquanto o impulso formal exige leis. A exigência por formalidade absoluta por parte do impulso formal pode ser aproximada da ideia de ordenação que estaria conjugada a de conservação. Por outro lado, o impulso sensível só trata de casos que se dão no fluxo do espaço e do tempo e que não estão sujeitos à mesma ordenação formal. A ela escapa, o que pode indicar um ímpeto de se diferenciar ou se singularizar mais do que tentar se colocar de uma forma transgressora em uma tentativa de ordenação.

Na obra de Nietzsche, notamos como tanto o princípio Apolíneo quanto o Dionisíaco nutrem uma relação de certa contraposição à realidade cotidiana. Ambos tentam não aderir a ela por completo ou recusá-la por completo, seja no sonho apolíneo ou na embriaguez dionisíaca. Ainda assim, há uma oposição maior que pode ser melhor aproximada da díade conservação-transgressão. O Apolíneo, que incide principalmente nas artes plásticas, ao trazer consigo o princípio de individuação, acaba por manifestar-se na forma de imperativos e prescrições. Enunciados como: "conhece-te a ti mesmo" e "nada em demasia" expressos na forma de leis indicam um chamado à justa medida ou à ordenação.

Por outro lado o Dionisíaco, que por sua vez incide sobre a música, escapa a estes anseios. Não se submete a processos de individuação ou é regido por prescrições. O transporte 
da embriaguez dionisíaca escapa à unidade e à individuação ao possibilitar cada subjetividade se colocar livre do ímpeto da individualidade, ao tentar se fundir com o Uno-primordial.

Ao usarmos a dupla de termos transgressão e conservação/ordenação, percebemos um leve desajuste na oposição quando aproximada daquelas contidas nos textos de Kant, Schiller e Nietzsche. Mesmo que o termo transgressão seja matizado pela ideia de singularização, que também pode ser oposta ao outro polo desta díade. Transgressão pode se entendida como a não conservação ou não ordenação, suas negações. Algo diferente acontece nas oposições encontradas nos impulsos/princípios daqueles filósofos alemães. Cada princípio se opõe ao seu par ao afirmar por si mesmo características intrínsecas que seriam completamente opostas ao de seu polo antagônico. Um polo não nega o outro: o sensível não nega o formal, da mesma forma como o Dionisíaco não nega o Apolíneo. Até mesmo o antissocial não nega o princípio socializante, ainda que o termo possa sugerir a negação, apenas indica um modo oposto à propensão natural pela socialização.

Uma vez que é preciso refletir sobre o modo como o ideal de formação ainda pode ser concebido na atualidade, tentei discutir no segundo capítulo desta dissertação a questão da falência dos ideais modernos. Para isso, fiz recurso à obra "A condição pós-moderna" de Jean-François Lyotard, assim como outras do mesmo autor, que tematizam tal questão ao discutir a 'pós-modernidade' como período em que os ideais modernos passam a ser vistos com maior desconfiança, levantando suspeitas sobre sua legitimidade.

Uma vez que foi preciso apontar a vinculação que notamos entre o ideal de formação e o projeto iluminista - que legitima a instituição escolar desde o advento da República francesa e seu sistema educacional que a tantos outros sistemas influenciou, assim como o nosso também se torna necessário discutir se, no cenário atual, o projeto de emancipação iluminista ainda sustenta a instituição de escolar e aquilo que chamamos de ideal de formação.

Por isso que julgamos necessário fazer recurso ao exame que Lyotard faz dos princípios de legitimação e como eles funcionam tanto na modernidade quanto no momento de sua falência ou derrocada. Assim, foi discutido como as metanarrativas faziam uso de discursos de legitimação para se afirmarem. Neste contexto, a tarefa educacional se viu na função de fazer dos homens cidadãos e emancipados.

Desta forma, foi importante acompanhar a argumentação de Lyotard, para entender de que forma os ideais modernos perdem a sua legitimidade. A legitimação pela busca da verdade que impulsiona a ciência carrega em si os germes de seu contrário. É o próprio processo de autolegitimação que a ciência põe em curso que leva à sua deslegitimação. 
Se não se pode mais fazer recurso à busca da verdade ou da justiça como pontos de legitimação, Lyotard propõe que um outro princípio passa a se impor: o do desempenho. Ao descrever e discutir este princípio, foi possível melhor entender em que se fundamenta o idioma do mundo que é falado pelos jovens no texto "Mensagem a propósito do curso filosófico". Idioma que, como vimos, é incomensurável em relação ao idioma do curso filosófico, o que leva a um diferendo entre alunos e professor.

Não se trata ainda de tentar resolver este diferendo, se é que algo assim é possível, ou de entendê-lo melhor. Mas é que é na força cada vez maior deste princípio de desempenho que os intentos formativos vêm se mostrando menos profícuos. Assim, podemos inferir que este novo cenário - cada vez mais regido pelo princípio de desempenho e seus critérios passa a apresentar grandes impedimentos, tanto para o ideal de formação quanto para o 'curso filosófico' baseado no exercício de escuta, próximo à anamnese.

Identificado este problema acerca da forma como o ideal de formação ainda pode fundamentar, ou ao menos permear, tanto os intentos educacionais como os objetivos do ensino de Filosofia, foi possível encaminhar o debate que foi proposto para o capítulo seguinte. Ainda ao final do segundo capítulo poderíamos inferir três distintas maneiras de lidar com o problema da relação entre o ideal de formação e o ensino de Filosofia. De forma resumida, estas maneiras seriam: tentar preservá-lo em seu cerne, rejeitá-lo por completo, reexaminar os seus fundamentos e como fundamentaram nossa prática.

Antes de iniciar o debate apontado, trato de maneira breve, o modo como alguns documentos da SEAF, discutiam o reingresso ${ }^{92}$ da Filosofia nos currículos escolares no findar da ditadura civil-militar. Ali, julguei importante ressaltar que o contexto nos fornece muito para entender algumas apostas e confianças depositadas na presença da disciplina. Ainda assim, para além destas expectativas os documentos também apresentavam problemas, como a questão da formação dos professores e o cuidado dispensado ao núcleo humanístico do currículo.

No entanto, a questão central que o recurso a tais documentos pôde mostrar foi o ponto em que em que era possível encontrar um tom formativo nos discursos presentes em tais documentos ${ }^{93}$. Entendo que isto pode ser dito a partir da ênfase pela cidadania e criticidade,

\footnotetext{
${ }^{92}$ Sobre o 'reingresso' da disciplina, conferir nota 35.

${ }^{93}$ Ao examinar quem fez parte deste movimento naquele momento e comparar com quem são os autores que discutem o ensino de filosofia nos últimos dez anos ou um pouco mais, podemos notar algo que discutirei brevemente mais adiante. Se naquele período, houve um engajamento maior por parte dos departamentos de filosofia de diversas universidades, o que passou a ser visto no segundo momento, foi a presença de professores provenientes das faculdades de educação nas universidades tomando a frente do debate.
} 
pontos fortes em que a Filosofia poderia se firmar para se justificar enquanto indispensável à formação escolar dos jovens brasileiros, sobretudo naquele momento.

Ainda assim, vimos que havia uma preocupação por parte dos participantes daquele movimento em reconhecer que, nos momentos em que suas reivindicações pudessem ser atendidas, isto poderia ocorrer a partir de uma leitura apressada de suas proposições, acarretando a possíveis retrocessos. Conforme apontei, isto se daria ao colocar a Filosofia como um saber positivo, esvaziado de seu potencial crítico e radical, mas talvez com um caráter moralizante.

Tais esforços, expectativas e motivações aparecem de alguma forma não somente nos diversos textos que discutem o ensino de Filosofia, mas também naqueles em que examinei as possíveis relações entre a ideia de formação e o ensino de Filosofia.

Entre os modos de discutir tal relação apontei em uma série de textos de Franklin Leopoldo e Silva uma tendência em entender uma permanência do ideal de formação nos desígnios do ensino de Filosofia.

Parto inicialmente da caracterização que o autor faz da formação como algo que exerce uma postura crítica em face da fragmentação. Uma vez que haveria uma fragmentação da experiência no mundo contemporâneo, o discurso filosófico teria a capacidade de propiciar uma ordenação reflexiva da experiência face a razão instrumental. Assim os intentos formativos se colocam em oposição àquilo que Theodor Adorno e Max Horkheimer chamaram de razão instrumental ${ }^{94}$.

A ênfase e o cuidado em discutir o tema da formação é frequente nessa série de textos, e vão além da questão da fragmentação da experiência. $\mathrm{O}$ ensino de Filosofia, tal como propõe o autor, deve sempre reafirmar sua força interrogante - característica que parece ser o essencial de tal exercício - e questionadora, evitando se colocar como um saber positivo.

Tal força interrogante, cujo estilo devemos tentar propor que nossos alunos assimilem, deve ser apresentada jamais por força de algum interesse maior. $\mathrm{O}$ autor nos adverte que em nome de uma certa ideia de formação pode estar somente a disseminação de dogmas tentando disfarçar o interesse individual, corporativo ou do Estado.

Para além disso, o ensino de Filosofia que se orienta pela prática do questionar também não pode ser confundido com um saber-fazer, reduzido a uma finalidade ou função pragmática. Ao contrapor formação e treinamento, vimos como o autor enfatiza a forma como

\footnotetext{
${ }^{94} \mathrm{O}$ recurso a esta noção dos filósofos da Escola de Frankfurt tem importância significativa nas propostas de Leopoldo e Silva, de modo que trataremos adequadamente mais adiante. Será útil também aproximar esta noção à alguns temas encontrados na filosofia de Lyotard e examinar suas semelhanças e confluências.
} 
a Filosofia realiza o exercício, de uma maneira própria, que não estaria acessível a outras disciplinas, a de ensinar conteúdos, estruturas e padrões integrados às suas gêneses e condições de possibilidade. Visto que o aprendizado em nível médio é caracterizado por uma etapa de reconhecimento das formas pelas quais se aprende algo e do conteúdo daquilo que é aprendido - algo que não acontece nas etapas iniciais de ensino - o ensino orientado por esta ideia específica de formação se torna mais apropriado para privilegiar sua força interrogadora, pois não dispensa que os objetos aprendidos o sejam de acordo com as razões que possibilitaram sua emergência ou formulação.

Acerca do que foi mais uma vez apontado e destacado sobre o ideal de formação nos escritos de Leopoldo e Silva, creio que é possível inferir que tal ideal ainda permanece como princípio regulador, como um horizonte que permite orientar e planejar as ações. Isto não significa retomar a aposta nas pretensões emancipadoras do Iluminismo, fazendo tábula rasa da nãorealização de seus intentos.

Frente a uma perspectiva que vislumbra uma certa permanência do ideal de formação nos intentos do ensino de Filosofia, discutimos uma outra, da qual podemos dizer que concebe um afastamento ou até o abandono do ideal de formação. Em ambos os autores de que fizemos uso para pensar tal perspectiva, Walter Omar Kohan e Silvio Gallo, encontramos a formação vista em uma chave negativa. Sua ideia é, em geral, apresentada como estando a serviço de fins conformadores ou cerceadores daquilo que poderia produzir o novo, o singular ou a diferença. Desta forma, para tais autores, ela deve ser abandonada, ou não levada em conta, como princípio orientador de qualquer prática educacional.

Uma vez que entendem a formação como um fabricador de certo modelo de pensar conformado a um fim pré-determinado, os autores sugerem uma educação que afirme a novidade da infância ou uma 'educação menor'.

Também foi importante destacar como os autores associam os intentos formativos à modernidade, uma etapa que para eles - assim como para Tomaz Tadeu da Silva - estaria vencida e sendo sucedida por outra ${ }^{95}$. O exercício de resistência proposto pelos autores visaria singularizar e produzir diferenças, as quais a insistência nos ideais modernos acabaria por bloquear, pois uma educação formativa voltada a fins pré-determinados não faria mais do que gerar conformidade e produzir sempre o mesmo.

Um apontamento breve que é necessário fazer sobre um aspecto, de razoável importância, é o da argumentação de Kohan. Ao defender uma educação que deve lidar com a

\footnotetext{
95 Alegação que, como já apontamos, é polêmica e voltará a ser discutida.
} 
infância e que opte por não cooptá-la para qualquer tipo de fim - o de conservação do mundo ou de transformação do mundo, que são entendidas pelo autor como sendo, em última análise, igualmente conservadoras - existiria nesta defesa um pressuposto? A saber, que a educação escolar é a única instância que 'forma' a infância no sentido de uma cooptação para fins prédeterminados. E que, portanto, nenhuma outra o fará.

Ainda assim, por mais que seja o caso de convir que a concepção de ideia de formação apresentada pelos autores esteja bastante arraigada a fins conformativos, é importante notar como tais propostas estão especialmente atentas a um perigo já reconhecido pela militância em torno da luta pela efetiva inclusão da Filosofia no fim do estado de excessão: reduzi-la ao papel de um saber positivo e moralizante.

Ao discutirmos os escritos de Celso Favaretto, percebemos um posicionamento outro em relação à nossa questão. Não se trata de colocar sua posição a meio-termo das outras duas, mas distingui-la como não demasiado próxima ou afinada com elas, ainda que aproximações e similaridades sejam concebíveis.

O pressuposto inicial que permite tal colocação, e uma leitura mais adequada às propostas do autor para a educação e para o ensino de Filosofia, é o de que testemunhar a falência do projeto moderno não implica obrigatoriamente seu total abandono ou o enterro de suas pretensões.

É tão necessário lançar suspeitas ao projeto Iluminista quanto é urgente revisar suas intenções em seus sucessos e fracassos, sem nunca deixar de perceber que ainda carregamos conosco muitos de seus pressupostos.

O trabalho que restaria fazer - e que isto não seja motivo para lamentos - é de colocar em ação o reexame daquilo que não se cumpriu, ou que se realizou de forma diversa da projetada. Neste ponto que a influência da ideia de anamnese de Lyotard se faz presente. O que se relaciona bastante com a concepção deste filósofo sobre o que seria a modernidade e o que seria o pós-moderno ${ }^{96}$. Daí o curioso exercício proposto de reiteração. É preciso se afastar dos discursos que adotam a forma de lamentos, de "perda de sentido" ou "crise de valores". Se um sentido unívoco, fornecido por uma metanarrativa, não pôde ser alcançado, isto não impede de buscar múltiplos sentidos, a partir de como os projetos não realizados nos levaram a modos de pensar, viver ou agir diferentes, também entre si, daqueles concebidos pelos projetos modernos. O saber, que deixa de ser magnetizado pela ideia de emancipação como

96 Cuja relação temporal discutiremos adiante, conforme apontei na nota anterior. 
era antes, vai perdendo seu poder elucidativo de desvelar uma verdade escondida e redentora, para ser mais interpretativo.

Isto leva Favaretto a reter a tradicional imagem da formação para a ela contrapor o que pode ser proposto para o nosso cenário pós-moderno. Um ponto que julguei oportuno explorar é a relação da formação com seus fins. Termo que não pode ser pensado sem sua ambiguidade. A formação, nesta imagem tradicional, visa uma finalidade que se dá quando atinge seu acabamento, seu término. Kohan e Gallo exploraram a formação pela via de que esta empreende uma ação com um fim pré-determinado. Para Favaretto, o trabalho com a Filosofia, que, inspirado na anamnese, exerce um "exercício de escuta" acabaria por extrapolar a relação com o tempo. Isto ocorreria ao suspender-se a ideia de acabamento. Nesta nova imagem da ideia de formação, não haveria fim a ser atingido em um transcorrer de tempo programado, o que não implica necessariamente em negar qualquer tipo de finalidade. Uma educação simplificadora ${ }^{97}$ ou excessivamente conformadora é claramente reativa, mas abrir mão de toda e qualquer finalidade não parece ser uma consequência imediata diante disso.

Este apontamento parece ter alguma relação com a polêmica sobre o que distingue o moderno do pós-moderno. Ressaltamos que Kohan e Gallo, nos textos discutidos, não advogam por uma educação pós-moderna, de forma explícita. No entanto, em diversos momentos relacionam os intentos formativos aos projetos modernos. Assim como apontei que a única pista para aproximá-los de uma ideia de pós-moderno seria a citação, destacada no terceiro capítulo, que Gallo faz de Antonio Negri ${ }^{98}$.

Dessa maneira, julguei que o modo como Tadeu da Silva concebe o pós-moderno, como radicalmente diferente do moderno, poderia ser suficiente para afirmar que a descrença ao ponto de abandono dos ideais modernos se dá pelo seu esgotamento ter como consequência uma etapa completamente diferente daquela. Desta forma, os ideais modernos poderiam ser descartados e facilmente substituídos por algo melhor.

Neste ponto, as propostas de Favaretto parecem ser suficientemente distintas, uma vez que julga que o ideal de formação deve ser considerado e que o Iluminismo ainda está presente em muito da forma como pensamos e agimos.

Acerca da separação brusca entre modernidade e pós-modernidade, percebemos que as avaliações feitas por Lyotard sobre a polêmica - que foram discutidas no quarto capítulo,

\footnotetext{
97 Vimos como Lyotard pensa que o saber é sempre complexo e que a educação deve formar para o discernimento e a complexificação.

98 Naquela citação, Negri fala que vivemos na "época do pós-moderno" em que o esgotamento da figura do profeta leva a afirmação do papel do militante.
} 
sobretudo nas passagens sobre a 'reescrita' da modernidade - parecem ser suficientes para entendermos que tal alegação de Tadeu da Silva aparenta ser ao menos apressada.

Há de se notar que a visão de formação daqueles autores é apresentada como sendo unívoca, o que não se repete em autores como Jorge Larrosa (2003, p. 31,32), também citado por Kohan (2005,p 236) em um de seus textos. ${ }^{99}$ Para Larrosa, podemos pensar em formação a partir de dois aspectos: um que dá forma e desenvolve disposições preexistentes, e outro que leva a conformar-se com um modelo que foi preestabelecido anteriormente.

Sugeri no primeiro capítulo algo que também destoa daquela univocidade da formação e que parece ir ao encontro da duplicidade pensada por Larrosa. Naquele momento - como repeti também no início desta seção - lancei a hipótese de que todo ato formativo coloca em jogo duas ideias distintas, talvez opostas: a de conservação e a de transgressão. Desenvolver predisposições não significa o mesmo que transgredir, mas implica em não se conformar a uma mesma coisa e ir além do estado em que se encontra. Mesmo Larrosa, naquele texto, aposta em uma ideia de formação que se apoia somente no primeiro aspecto, tentando escapar da força do segundo. Seria isto possível?

Levando em conta a caracterização feita por Larrosa, vimos no primeiro capítulo que a ideia de formação traz consigo tanto esta dimensão de desenvolvimento do que possuímos potencialmente, para nos tornarmos algo que antes não era possível ser, quanto a dimensão de que é necessário o contato com a alteridade, e isto inclui modelos que pedem ou exigem algum tipo de conformação a uma forma dada anteriormente. É possível separar estas duas dimensões? Uma que visa um desenvolvimento para nos tornar singulares, de outra que exige a conformidade com um modelo? Podem ser cindidas ou conciliadas estas duas instâncias em que uma singulariza e diferencia e uma outra que conforma?

Mesmo a Filosofia em suas manifestações na história, como visto nos textos de Favaretto, também carrega uma aporia similar. Ao mesmo tempo em que carrega consigo pretensões de se assumir como saber soberano, também demonstra escapar dessa pretensão, resistindo a ser catalogada como um saber cadastrado. Da mesma forma, sua intenção formativa tenta a Filosofia a se comportar tal como um saber totalizante acima de todos os outros, mas sem deixar de se mostrar também resistente a tais totalizações em diversas de suas manifestações ao longo de sua história.

Um impulso para se elevar diante dos demais saberes, de forma totalizante, esforçando-se se para colocar tudo de acordo com seus ditames. Outro que resiste a essas

99 O texto em questão é: "Uma educação da filosofia através da infância". No entanto, Kohan se vale de um texto distinto do que é aqui apresentado. 
totalizações ou conformações, que visa se singularizar em relação a estas pretensões. Desta forma, ao pensarmos a Filosofia em sua tarefa formativa, encontraremos sempre estes dois caracteres?

A conciliação não parece possível entre estes dois regimes incomensuráveis entre si. Mas uma questão ainda permanece. No cenário pós-moderno, esta aporia que está contida no ideal de formação persiste sob alguma forma? Talvez a chave esteja na relação entre a noção de acontecimento e de narrativa, ou de metanarrativa, proposta nas obras de Lyotard.

$\mathrm{O}$ acontecimento, conforme a leitura aqui proposta, pode ser entendido como a ocasião em que algo irrompe de uma forma singular, que exige uma nova forma de recepção a qual nossa sensibilidade ainda não concebia nem podia exercer. A narrativa propõe uma estrutura e determinadas regras para encadear cada acontecimento - entendido aqui em um sentido mais amplo $^{100}$ - ou cada frase, para manter a inteligibilidade e coerência proposta de antemão. Ou seja, tudo o que acontece deve ser entendido de uma forma antes prevista que seja coerente às regras de encadeamento daquela narrativa. Portanto, a estrutura da narrativa concebe uma ordem conformadora que procura se opor diante da pragmática desordenadora do acontecimento.

No segundo capítulo, discutimos como a narrativa, nas formas de histórias ou lendas, traz nos seus conteúdos modelos felizes ou infelizes de integração às instituições estabelecidas de um povo. Desta forma, a narrativa se presta ao papel de consolidar as normas que regem a convivência de uma comunidade e a continuidade de sua cultura, e também em muitos casos, protegendo-a da violência ameaçadora do acontecimento. Claro é que nenhuma narrativa é forte ou inerte o suficiente para manter suas instituições inalteradas diante de qualquer tipo de acontecimento, dada a sua imprevisibilidade.

Se o jogo entre singularização e conformação marca todo ato que se pretenda formativo, Lyotard parece nos indicar que o cenário pós-moderno traz perigos que devem ser reconhecidos.

Para encaminhar a discussão que propus acerca dos temas presentes na filosofia de Lyotard que guardam conexões com a educação e o ensino de Filosofia, mobilizei a seguinte pergunta: O que pode se esperar da Filosofia, uma vez que ela não se orienta para a emancipação?

${ }^{100}$ Fabbrini (2005, p. 24) usa as expressões "acontecimento em sentido fraco" e "acontecimento em sentido forte". 
Para além do tema do acontecimento, outros foram levantados. De forma que só foi possível atingir o ponto em que era possível debater sobre a noção de acontecimento após um trajeto sobre outros temas e discussões.

Uma vez que muito desta dissertação é motivado pela relação entre professor e aluno com os seus respectivos idiomas - na situação pós-moderna, achei oportuno fazer a referência ao texto em que Lyotard reconsidera o uso do prefixo 'pós' para relacionar a modernidade, optando por passar a fazer uso do prefixo 're' contido em 'reescrita'. Com isto, acompanhamos a argumentação de Lyotard para recolocar a relação que a modernidade tem com os seus fins.

Se o intento daquele capítulo estava em poder repensar a tarefa educativa - desprovida de um fim formativo emancipatório - foi preciso discutir essa relação da modernidade com suas finalidades, algo que já era possível notar de forma implícita, na análise feita dos autores que discutiam o ensino de Filosofia, conforme apontei há pouco ${ }^{101}$. Assim, o esforço por reescrever a modernidade se coloca de modo a se eximir de buscar as causas pelos fracassos dos projetos, como se fosse possível expiar uma culpa ou se redimir dos erros passados, o que levou ao exame da relação que há entre a anamnese - que ao lado do trabalho de criação das Belas Artes eram os modelos para a reescrita da modernidade - e a escritura, e também o jogo entre escritura e escuta.

A elaboração da noção de escritura, inspirada na anamnese, se mostra crucial para entender o exercício de escuta que é proposto no 'curso filosófico' 102 e que fundamenta muito do que foi colocado, e aqui discutido, por autores como Favaretto e Fabbrini.

Por isto, acreditei ter sido importante destacar o modo como Lyotard caracteriza este trabalho de escritura, que se inicia sem saber o que dizer, nem como dizer e menos ainda a forma daquele que o escutará. O curso filosófico, assim como a escrita filosófica, entra em curso desta forma ao tentar desenvolver as possíveis escutas daquilo que está contido e foi desenvolvido nestas escrituras ou escritas.

Da mesma forma, a escritura presente na tentativa de reescrita da modernidade visava também ira à busca do que não foi percebido, mas o faz sem a dimensão do projeto. $\mathrm{O}$ curso

\footnotetext{
${ }^{101}$ Discussões presentes no terceiro capítulo sobre o modo como Kohan e Gallo pensam na ideia de formação como conformação a fins pré-determinados e como Favaretto elabora uma nova ideia de formação em uma relação outra com a temporalidade.

102 "Escreve-se antes de saber o que há a dizer e como, e para o saber, se possível. A escrita filosófica está adiantada em relação àquilo que deveria ser”(LYOTARD, 1993a, p.122).
} 
filosófico também não projeta seu fim antes de se por em curso ${ }^{103}$, coloca-se em marcha de maneira incerta e indeterminada. Somente durante seu percurso podem ser encontradas uma forma ou uma inteligibilidade que não podiam ser imaginadas ou projetadas antes.

Como destaquei, isto permite ir ao encontro não da 'diferença' ou da 'alteridade', mas com o impensado. Aquilo que não encontrava expressão possível, que não possuía idioma próprio para ser dito nem um arranjo de frases adequado para tanto. $\mathrm{O}$ que leva a importante noção de diferendo que se torna central para a filosofia de Lyotard $^{104}$.

Lembremos que a noção de diferendo já estava presente no 'curso filosófico'. Dois regimes de discurso que são incomensuráveis entre si e que não podem ser arbitrados por uma terceira instância: o idioma falado pelo mundo e pelo aluno e o idioma falado pelo 'curso filosófico'. Se no caso dos diferendos caracterizados em "Le differend", apenas o lado em que seu prejuízo não ganha expressão em um idioma era considerado vítima, no outro caso há vítimas dos dois lados, aponta Lyotard (1993a, p. 125). Professor e aluno são vítimas um do outro.

Aqui podemos retomar, a pergunta formulada parágrafos atrás, que ficou sem resposta. Haveria, no atual cenário, uma persistência da aporia ou do jogo entre singularização e conformação que estavam contidos no ideal de formação? Ora, já foi colocado em diversos momentos que não se pode mais projetar a mesma esperança neste jogo que visava a emancipação. Se, para alguns, é importante apontar que, se nos livrarmos dos perigos da conformação, abrem-se espaços para a singularização, Lyotard parece nos indicar uma outra via.

Para falarmos em um esforço de preservar a possibilidade de singularização nos escritos de Lyotard, temos que recorrer ao que aparece em termos como 'Inumano', 'no men's land', 'parceiro estranho', conforme apontamos. Trata-se desta instância que nos ocupa e da qual temos pouco ou nenhum controle; ela que nos desassossega, nos impede de sermos sempre os mesmos, nos perturba e nos faz pensar. É precisamente essa região humana que está sob perigo no atual cenário, aponta Lyotard. Perigo que guarda semelhança com o pesadelo totalitário orwelliano que não se concretizou. Ou seja, não somos vítimas de um

103 “É preciso re-começar. O monstro criança não é o pai do homem, é no meio do homem o seu de-curso, a sua deriva possível, ameaçadora. Começa-se sempre pelo meio. É por isso que um projecto de um curso filosófico, projecto que vem das ciências exactas, parece votado ao fracasso" (p. 120)

104 Após a "Condição pós-moderna" de 1979, a ideia de diferendo passa a estar presente em boa parte dos textos que fazemos uso nesta dissertação para pensar as conexões entre a filosofia de Lyotard e a educação. Após "Le differend" de 1983, temos a "Mensagem a propósito do curso filosófico" de 1984, "Glosa sobre a resistência" de 1985, "Prefácio: do humano" (prefácio ou primeiro capítulo de "O inumano") de 1988 e "Um parceiro estranho" de 1993. Nestes textos, a ideia de diferendo é não somente central, mas também o que mobiliza em grande parte as discussões propostas. 
extenso domínio conformador ou repressor que inibe a expressão do singular, fazendo que a ordem imponha somente a repetição do mesmo. Pelo contrário, somos forçados a nos expressar a todo custo e a nos manifestar e reivindicar o que temos direito de ser, de fazer ou de pensar. Impelidos a buscar o novo, propor o novo, até mesmo ser o novo. Aí é que reside o perigo a nossa região inumana, que é pressionada pelo regime da pressa e da velocidade que caracterizam o idioma falado pelo mundo.

Aqui chegamos a dois pontos, para finalizar essas considerações, que já desistiram de ser breves. Primeiro, tentarei pensar qual grau de afinidade parece haver neste perigo do predomínio do idioma do gênero econômico ou do princípio legitimador do desempenho, elaborados por Lyotard, em relação à ideia de razão instrumental que é discutida por Leopoldo e Silva e também por Fabbrini. Feito isto, tento pensar nestes 'perigos' e problemas do diferendo apontados por Lyotard no 'aqui' e no 'hoje' das nossas aulas de Filosofia ministradas no Ensino Médio, pensando nos jovens que hoje encontramos, e com que frases e idiomas estão mobilizando e manifestando seu pensamento.

Ao retomarmos nestas considerações a discussão que Leopoldo e Silva propõe para o Ensino Médio, destacamos como ponto nevrálgico a tentativa de se antepor frente à fragmentação da experiência e ao predomínio da razão instrumental. No artigo "A perda da experiência da formação na universidade contemporânea", Leopoldo e Silva (2014, p. 86, 87) discute a partir de um texto de Adorno ${ }^{105}$ como a não realização do projeto da modernidade de emancipação da razão, junto com a falência do humanismo clássico - por não poder mais vincular as ideias de consciência, verdade e felicidade - se mostram concomitantes ao predomínio da razão instrumental.

Não podemos certamente recuperar essa esperança, mas podemos ao menos tentar
compreender as causas que a tornaram frustrada. Na impossibilidade de um exame
mais pormenorizado dessas causas, diremos apenas, alertando para a inevitável
simplificação, que o processo de desenvolvimento da razão emancipada - aquela
que se pretendia como sustentáculo de um equilíbrio perfeito entre a teoria e a
prática - provocou efeitos civilizatórios contrários aos seus pressupostos,
exatamente pela impossibilidade de manutenção desse equilíbrio entre a razão como
meio da produção de instrumentos científicos e técnicos de aprimoramento da
civilização, e a mesma razão como discernimento dos fins humanos a que tais
instrumentos deveriam servir, para o efetivo aprimoramento da vida. É precisamente
esse desequilíbrio, e a conseqüente prevalência dos meios, isto é, da razão
puramente instrumental, que nos coloca hoje na posição, impensável para um
humanista clássico, de poder enunciar a pergunta: progresso - para quê? Isso
significa que a separação entre meios e fins, que na origem tinha o propósito de
permitir a articulação das duas instâncias na unidade da razão, tornou-se um
isolamento e uma desconexão total e absoluta entre meios e fins, o que tende a fazer

$105 \mathrm{Na}$ verdade um debate radiofônico com Helmut Becker que recebeu o título de "Educação - para que?" contida na coletânea "Educação e emancipação". 
da racionalidade técnica e instrumental uma força cega, empenhada numa trajetória que acabou por fazer de si própria a única referência de percurso.

Apoiado nos termos propostos pelo debate adorniano, Leopoldo e Silva também não concebe esperanças na retomada do projeto moderno, da mesma forma que Lyotard apontava em Habermas o quão inócuo seria tal esforço. Ainda que a tentativa de elucidar as causas da não realização do projeto moderno afaste a leitura que Leopoldo e Silva faz de Adorno do posicionamento que Lyotard assume em "Reescrever a modernidade", voltamos a encontrar um tema comum que é o desenvolvimento ‘cego' dos meios e das técnicas que não se apoiam mais em fins humanísticos ou emancipatórios.

Este declínio do 'projecto moderno'(...) é acompanhado pelo desenvolvimento quase exponencial da tecnociência. (...) Nunca a descoberta científica ou técnica foi subordinada a uma procura com origem nas necessidades humanas. Foi sempre movida por uma dinâmica independente daquilo que os homens podem pensar que é desejável, proveitoso, confortável. (LYOTARD, 1993a, p. 102,103).

Por mais que esta autonomização da ciência e das técnicas possa ser melhor notada no momento de falência do projeto moderno, Lyotard nos adverte para a questão de que é próprio da ciência buscar seus próprios meios de legitimação, o que faz com que contenha em si o motor de sua deslegitimação, como já discutimos. Ou seja, o desenvolvimento da ciência nunca teria subordinado ou legitimado por necessidades humanas ou ideais humanistas.

Há outro aspecto em que pode ser propício fazermos uma aproximação entre ideias de Adorno e de Lyotard, a fim de saber se há pontos de contato. Indicamos em vários momentos o modo como Lyotard afirma que os jovens alunos falam um idioma regido pelo sucesso, pela velocidade ou pelo gozo, um idioma que é o idioma do mundo. No diagnóstico de Adorno $(2000$, p. 144, 145) haveria um "conformismo onipresente" que faz com que as crianças e os jovens adiram a um "realismo supervalorizado", forçando-se em demasia para sua adaptação à realidade. Não se trata, neste apontamento de Adorno, de discutir a linguagem que os alunos fazem uso nas situações educacionais, mas apontar como comportamentos e posturas seguem uma heteronímia, assim como ao falarem o idioma do mundo, os jovens não o fazem por livre vontade ou determinação, mas cedem a pressões exteriores sem a devida reflexão ou elaboração. Assim, parece que nos dois diagnósticos, mesmo com suas peculiaridades intrínsecas, temos a presença de uma força por adaptação e uma conformação que atinge os jovens sem que isso seja percebido, seja para falarem um idioma que, com sua pressa, 
atropela o lento, contínuo e errante processo do "exercício de escuta", seja para resistir aos ditames do "mundo administrado" apostando em alguma ideia de emancipação.

De forma similar, Fabbrini (2005, p. 12) concebe, em suas propostas para a Filosofia no espaço escolar, que os esforços baseados e inspirados no "exercício de escuta", no perspectivismo ou no exame cuidadoso dos textos em sua imanência, exerceriam resistência a forma como a o predomínio da razão instrumental provoca o risco de a linguagem se tornar inerte e petrificada, sem seu poder de negatividade diante do que está estabelecido.

Desta forma, é importante notar como Adorno insiste em apostar na ideia de resistência e de contradição para os intentos educacionais, uma vez que a pressão para a conformação e adaptação são dominantes naquilo que ele chama de "mundo administrado" (p. 144,145, 150,151). Ainda que ele reconheça as dificuldades de se conceber a tarefa da formação sem a convivência entre processos de conformação e individualização.

Helmut Becker, neste debate radiofônico com Adorno (p. 142, 143), expressa uma opinião que nos ajuda a pensar no segundo ponto que propus para encerrar o que estamos a discutir nestas considerações finais: "Poderia apresentar um argumento que talvez muitos professores apresentariam a partir de sua prática. Eles diriam: a juventude não deseja uma consciência crítica. A juventude quer modelos ideais (...)”. Ainda que todos que frequentam escolas e salas de professores já tenham ouvido frases com teor semelhantes, é importante marcar - o que pode ser confirmado pela discussão precedente - que essa tendência apresentada por Becker é somente fruto das pressões que o mundo administrado impõe, colocando os alunos na posição de vítimas de algo bastante difícil de se opor. Portanto, não tomemos tal argumento em seu frequente uso conservador, que coloca na falta de interesse ou motivação dos alunos a razão para os problemas da educação ${ }^{106}$.

Acatemos, por ora, este argumento: a juventude prefere um modelo ideal para suas condutas. Examinemos outra, mais uma vez recorrendo ao idioma falado pelo mundo: o jovem se orienta pela velocidade e posiciona seus propósitos guiados pelo sucesso e pelo gozo. É isto que estamos vendo nas posturas dos alunos atualmente nas salas de aula?

Sobre este despertar para uma criticidade - pretensão e desejo pra lá de frequentes na história do exercício do ensino de Filosofia - creio que possa ser aproximado da 'sede de verdade' para a qual apontava Lebrun, e de que fizemos referência no terceiro capítulo. De fato, muitas das nossas expectativas para que os alunos joguem os jogos da maneira que propomos - e que acreditamos serem pertinentes para melhor aprendizagem ou mesmo para

${ }^{106} \mathrm{O}$ mesmo talvez pudesse ser dito da suposta aversão do jovem à politização. 
uma melhor formação - são frustradas, pois em grande parte das vezes os alunos, simplesmente, ou não querem jogar de acordo com tais regras, ou não as entendem, ou preferem propor outras. Atitudes difíceis de serem discernidas. E o parecer de Lebrun é interessante, pois é bastante notável que percebemos alunos carentes por algum tipo de orientação, que de algum modo se percebem pobres de instrumentos para se colocar diante da realidade percebida, ainda que os indícios para esta avaliação sejam casuais, discretos e não tão frequentes. Sendo assim, o argumento posto por Becker pode ter bastante sentido, uma vez que para quem se mostra desorientado, apegar se a um modelo ideal pronto satisfaria seus anseios de forma mais célere. Sabemos que o caminho proposto por Lebrun é outro, o de dotar o jovem de uma língua de segurança. Mas o que acontece se for verdade que os interesses dos alunos já estão fixados conforme aponta Favaretto? Se o interesse dos alunos só puder ser acessado pelas vias daqueles preceitos do idioma do mundo (sucesso, gozo ...)? Vias com as quais, é importante não esquecer, a Filosofia nunca teve muita afinidade.

A questão sobre o melhor modo de despertar o interesse dos alunos se torna cada vez mais premente nos debates educacionais, em suas mais diversas formas. A prerrogativa por recorrer a algum tipo de estratégia ou atividade pedagógica que ative o interesse do aluno, por vezes, se mostra com muito mais força do que a importância que se dá aos conteúdos ditos fundamentais. Para tal questão, podemos apresentar como estas estratégias foram vistas de forma negativa em duas ocasiões nos textos aqui discutidos ${ }^{107}$. Lyotard chamou de pedagogismo, essa atitude que cede aos anseios dos alunos, que visam sempre escapar aos meios de instrução escolares, por serem considerados excessivamente penosos. Assim como Fabbrini (2005, p.12) também recusa uma "ênfase na recepção" dos conteúdos filosóficos para os alunos com o intuito de além de facilitar a recepção do alunos, também focar no aspecto da fruição. A aposta do autor continua ser a de se orientar pela proposta lyotardiana de "exercício de escuta" e de anamnese, preservando a autorreferência dos textos.

A velocidade das transformações tecnológicas e principalmente dos dispositivos e gadgets portadores das mais diversas formas de comunicação e interação social tem colocado desafios ainda mais árduos aos professores em seus cotidianos. É importante afirmar, com a devida ênfase, que a ideia que o aluno forma do que é, e do como se dá o aprendizado, se transferiu da sala de aula para o ambiente virtual. O vasto mundo informacional em seus sistemas e linguagens é hoje, em muitos casos, mais facilmente acessado pelo jovem ou pela criança do que é pelos adultos, incluso seus professores, muitas vezes avessos ao uso da

${ }^{107}$ Ainda que o segundo ponto não tenha sido apresentado anteriormente. 
tecnologia ${ }^{108}$. O que parece ser determinante neste ponto é a questão da imediatez com que o estímulo ou pergunta é satisfeita nos sistemas de comunicação, no caso, a Internet. Se este é um ponto, o outro é a velocidade com que é possível obter informações desejadas com razoável precisão, com dispêndio de tempo mínimo. Creio que estes dois pontos têm exercido pressão desmedida sobre as tradicionais ideias de que a aprendizagem depende de tempo e do transcorrer de um processo, ideias contidas tanto na ideia de formação como também no curso filosófico lyotardiano. Assim como acredito que o que pode ser percebido nas posturas e anseios dos alunos que estão hoje nas escolas de Ensino Médio corroboram a visão apresentada por Lyotard e até a radicalizam.

Ainda assim, é razoável insistir em não adotar uma postura derrotista ou de lamento saudoso em nome daqueles alunos dóceis de outrora. Por mais que seja verdadeiro que os alunos falem o idioma da performance, do 'ganhar tempo'. Se permanecermos na atitude de falar um idioma que insiste que é importante 'perder tempo', o diferendo persiste. E talvez notemos que há outros diferendos no universo escolar.

O diferendo entre alunos e professores pode agora ser melhor aproximado daquele com o parceiro estranho que se recusa a explicar ou demonstrar de que forma joga seu jogo (LYOTARD, 1996, P.135-137). Os lances pelos quais joga o professor - seja visando alguma forma de emancipação ou operando alguma sorte de resistência - podem não ser tão bem entendidos pelo aluno como o eram em outros tempos. Assim como o jogo que jogam os alunos pode ser completamente estranho para o professor. Seguindo a sugestão de Lyotard que o razoável seria tentar aprender como se joga o jogo de nosso interlocutor, creio que seria igualmente razoável tentar descobrir com que regras e lances esse jogo misterioso se dá. $\mathrm{O}$ que provavelmente resultará em um jogo diferente dos anteriores. Não acredito que isto é o mesmo que fazer concessões, ou recair em 'pedagogismos' ou em uma “ênfase na percepção”. Mas que ainda é possível esforçar-se para - durante o exercício de escuta de cada texto ou assunto do conteúdo proposto - transparecer a forma como se joga o jogo, enquanto joga, ao

\footnotetext{
${ }^{108}$ Reduzir o problema a uma questão entre ser a favor ou contra a tecnologia, não passa de uma simplificação inócua. Seja quais forem os problemas, limites ou potencialidades do uso das tecnologias nas situações de aprendizagem, não podemos deixar de reconhecer que o jovem contemporâneo está completamente imerso e integrado a este universo da tecnologia e dos dispositivos de comunicação social e suas redes. Mesmo que recusemos o uso destas tecnologias, que na verdade ainda são inacessíveis para muitas redes de ensino no país. Segundo dados do PNE (Plano Nacional de Educação) 48\% das unidades públicas ainda não têm computadores para uso discente; $50,3 \%$ têm acesso à internet e há um computador para cada 34 alunos. A banda larga está presente em $40,7 \%$ das unidades. Os dados do PNE estão disponíveis em http://www.observatoriodopne.org.br/metas-pne/7-aprendizado-adequado-fluxo-adequado/estrategias/7-15acesso-a-internet-e-relacao-computadores-aluno/indicadores Acesso em: 18/01/2016, 14.50.
} 
mesmo tempo em que se interpelam as posturas dos alunos com seus jogos, cujos lances e regras, provavelmente, não são transparentes nem mesmo para eles.

Conforme já destacamos, o cenário atual nos provoca a pensar ou reavaliar as finalidades do ato educacional ou formativo. Ao seguirmos alguns aspectos da filosofia de Lyotard, no caso os problemas de projetar um fim determinado, assim como a identificação da não realização de determinados fins, poderemos chegar ao ponto de assumirmos uma postura.

Vimos que a projeção de fins, na condição pós-moderna, adquiriu um tom de maior complexidade e também proporcionou certa polêmica sobre suas possibilidades. Disto não inferimos que o ensino de Filosofia deixe de se prestar a todo e qualquer tipo de finalidade, ou que situar como objetivos a aprendizagem de determinados conteúdos é algo completamente infrutífero. Mas que, ao fazer uso de algum tipo de referente, retirado da história da Filosofia em suas diversas manifestações, busquemos algo mais do que o aprendizado de algumas teorias ou o assentimento sobre a validade de algumas proposições. Mas que seja possível inscrever, no trabalho com estes conteúdos, esta conversa que se dá consigo próprio e com cada indivíduo que povoa a sala de aula. A lentidão contida no exercício de escuta, oposta ao idioma do mundo, presente no curso filosófico ainda parece uma aposta bastante razoável para ser realizada em sala de aula ${ }^{109}$. Mesmo que os frutos a serem colhidos por tal modalidade de exercício ${ }^{110}$ sejam difíceis de serem avaliados, uma vez que não são projetados, ou dificilmente identificados. Trabalhar neste registro pode ser perturbador o suficiente, pois tenta se dispor para a irrupção por um acontecimento, do qual não há nenhuma garantia de que ocorra ${ }^{111}$.

Pouco importa se propostas desta natureza precisam se afastar de um modelo de aula entendida como tradicional, com alunos perfilados e com uma avaliação dos conteúdos minimamente compreendidos ou assimilados, ou se nada disso é necessário. Importa antes notar que o tipo de trabalho que Lyotard propõe colocar em curso não está sujeito ao mesmo

\footnotetext{
${ }^{109}$ Neste ponto, subscrevo o que Fabbrini $(2005$, p.23) aponta em nota de rodapé de seu artigo: "É claro que essa "escuta" do que "acontece no acontecimento", só é possível se a atividade do professor não for rotineira, massificada, sub-remunerada etc.". Ora, é importante se afastar de uma visão que acredita que os problemas educacionais serão resolvidas por boa vontade, por melhores ideias ou metodologias, com o real empenho de toda comunidade escolar ou se "todos falarem a mesma língua". Há questões de ordem material, concernentes ao histórico problema de financiamento da educação no país, que são determinantes para que melhores ideias, currículos ou propostas pedagógica - que vez ou outra podem estar sujeitos a revisões ou reformas - tragam efetivas melhorias.

${ }^{110}$ Lyotard (1993a, p. 122) enfatiza que isto se dá ao largo de exigências pedagógicas que venham a requerir metodologias ou estratégias.

${ }^{111}$ Perspectiva que para muitos pode ser tomada como irresponsável ou excessivamente voluntarista. No entanto quero situá-las bem distante dos 'pedagogismos' ou da "ênfase na recepção", estas sim, senão completamente irresponsáveis, certamente espontaneístas, desmedidas e amplamente desajustadas para esforços educacionais que considerem a situação contemporânea.
} 
tipo de avaliação, se é que está sujeito a algum tipo de avaliação. Afirmar isto coloca tal perspectiva, senão em acordo, ao menos em alguma consonância com a aposta que Gallo faz em uma "educação menor". Sem que haja a necessidade de concordar com a oposição entre 'maior' e 'menor', afirmamos que algo mais pode ocorrer ao longo do aprendizado dos conteúdos que já foram prescritos em parâmetros ou orientações escolares. Sem a necessidade de desprezá-los ou ignorá-los, há exercícios que podem compor uma aula de acordo com a perspectiva aqui assumida, e que ainda tomem como referente estes conteúdos.

Por fim, há uma outra oposição presente no mesmo artigo de Gallo que creio importante fazer referência, assim como a ela comparar uma outra oposição. A partir de uma citação de Negri, já comentada nesta seção e também no segundo capítulo, Gallo (2002, p. $170,171)$ propõe as opostas imagens do professor profeta e do professor militante ${ }^{112}$. Gallo aponta uma insuficiência para a atualidade deste exercício crítico de mostrar os problemas do presente para projetar a possibilidade do mundo novo. A militância, por sua vez, não promete, mas produz as possibilidades do novo.

Ao final do quarto capítulo, discuti a oposição que Lyotard elabora entre o intelectual e o filósofo. O intelectual restringe sua ação à defesa de um gênero de discurso com o intuito de garantir hegemonia ante os demais, neutralizando os diferendos e impedindo que se formem novos idiomas que poderiam expressar os prejuízos de vítimas de tais diferendos. $\mathrm{O}$ filósofo tenta encontrar o idioma - seja isso possível ou não - para que o prejuízo seja adequadamente expresso. Assim não se trata nem de prometer o 'novo' nem de construir suas condições. Vimos também, naquele capítulo, como Lyotard mostra reservas a ideia de novo e de novidade. O termo é de fato equívoco, sendo que a crítica feita por Lyotard não pode ser dirigida diretamente, sem a mediação adequada, ao que Gallo chama de novo. É suficiente afirmar que a identificação de diferendos, assim como a criação de idiomas antes inexistentes, é papel do filósofo e de alguma forma pode se estender para o professor de Filosofia.

Comentávamos, parágrafos atrás, que novos jogos surgem quando o professor tenta aprender de que forma seus alunos jogam. De forma análoga, o diferendo entre aluno e professor pode inaugurar um novo idioma? Nas passagens de "Mensagem a propósito do curso filosófico" o tom de Lyotard não parece assumir tal otimismo. Mas se o diferendo não propiciar um novo idioma, ao menos o testemunho do prejuízo de uma vítima já pode ser significativo.

\footnotetext{
${ }^{112}$ A oposição profeta e militante são feitas por Negri, usar os predicativos para professores é o que Gallo faz.
} 


\section{Bibliografia}

ADORNO, Theodor W. Educação - para que? In: Educação e Emancipação. São Paulo: Paz e Terra, 2000.

ALVES, Dalton José. A Filosofia no Ensino Médio: ambiguidades e contradições na LDB. São Paulo. Editora Autores Associados, 2002.

BENJAMIN, Walter. O narrador. Considerações sobre a Obra de Nikolai Leskov. In: Obras Escolhidas I. Magia e Técnica, Arte e Política. São Paulo, Brasiliense, 1996.

BRASIL -MEC. Parâmetros Curriculares Nacionais - Ensino Médio- vol. 4: Ciências Humanas e suas Tecnologias. Brasília: MEC/SEMT, 1999.

CARDOSO, Sérgio. Frágil Filosofia. In: NETO, Henrique Nielsen (org.). O Ensino da Filosofia no $2^{\circ}$ grau. São Paulo, Sofia Editora, 1986.

CORDEIRO, Denilson Soares. A formação do discernimento: Jean Maugüé e a gênese de uma experiência filosófica no Brasil. Tese de doutorado. Faculdade de Filosofia, Letras e Ciências Humanas da Universidade de São Paulo, 2008.

FABBRINI, Ricardo. O ensino de Filosofia: a leitura e o acontecimento In: Trans/ Form/Ação vol.28 no.1. Marília 2005.

FAVARETTO, Celso Fernando. Filosofia, ensino e cultura. In: Filosofia: Caminhos para seu ensino. Rio Janeiro, DP\&A, 2004.

Notas sobre o ensino de Filosofia In: ARANTES, Paulo Et

All (Org). A Filosofia e seu ensino São Paulo, EDUC, 1993.

. Pós-Moderno na Educação? In: Revista da Faculdade de

Educação da Universidade de São Paulo, São Paulo, vol. 17, no.1-2, FEUSP, 1991, pp. 121128.

. Transformação em processo. In: Conferência no Seminário

Nacional "Educação Integral: experiências que transformam”. São Paulo. Fundação Itaú Social/ UNICEF/Cenpec, 03/08/2012.

FLICKINGER, Hans Georg. Herança e futuro do conceito de formação (Bildung). In: Educação e Sociedade, Campinas, v32, n114, jan/mar 2011, p. 151-167.

FOUCAULT, Michel. O Que São as Luzes? In: Ditos e Escritos II: Arqueologia das Ciências e História dos Sistemas de Pensamento. Rio de Janeiro. Editora Forense Universitária, 2005.

GALLO, Silvio. Em torno de uma educação menor. In: Revista Educação e Realidade. Porto Alegre: Universidade Federal do Rio Grande do Sul, Faculdade de Educação, v.27, n.2, jul/dez, 2002. 
. Eu o outro e tantos outros. In: Regina Leite Garcia. (Org.). Diálogos Cotidianos. Petrópolis: 2010, v. 1, p. 231-246.

. A Filosofia e seu ensino: conceito e transversalidade. In: Renê José Trentin Silveira; Roberto Akira Goto. (Org.). Filosofia no Ensino Médio - temas, problemas e propostas. São Paulo: Loyola, 2007

GALLO, Silvio. ASPIS, Renata Lima. Ensino de Filosofia e cidadania nas "sociedades de controle": resistência e linhas de fuga. In: Pro-Posições, Campinas, v. 21, n. 1 (61), p. 89105, jan./abr. 2010

KANT, Immanuel. Ideia de uma história universal com um propósito cosmopolita. In: A paz perpétua e outros opúsculos. Lisboa. Edições 70, 2004.

. Resposta à pergunta: o que é o esclarecimento? In: A paz perpétua e outros opúsculos. Lisboa. Edições 70, 2004.

KOHAN, Walter Omar. Uma educação da Filosofia através da infância. In: KOHAN, Walter (Org.). Ensino de Filosofia: Perspectivas. Belo Horizonte. Autêntica, 2005.

O ensino da Filosofia frente à educação como formação. In:

GALlO, Silvio. CORNELLI, Gabriele. DANELON, Marcio. (Org.). Filosofia do ensino de Filosofia. Petrópolis. Vozes, 2003.

LAROSSA, Jorge. La experiencia de la lectura. Mexico, D.F. Fondo de Cultura Económico, 2003.

LEBRUN. Gerárd. Por que Filósofo? In: Estudos Cebrap, 15. São Paulo, 1976.

LEOPOLDO e SILVA, Franklin. Currículo e formação: o ensino de Filosofia. In: Síntese Nova Fase, v. 20, n. 63. Belo Horizonte, 1993.

História da Filosofia: formação e compromisso. In: Trans/

Form/Ação vol.25. Marília, 2002.

A perda da experiência da formação na universidade contemporânea. In: Universidade, cidade, cidadania. São Paulo, Editora Hedra, 2014.

Por que Filosofia no segundo grau. In: Estudos avançados 6 (14), Universidade de São Paulo, 1992.

LYOTARD. Jean-François. Condição Pós-moderna. Rio de Janeiro. José Olympio, 2011. . O pós-moderno explicado às crianças: correspondência 19821985. Lisboa: Publicações Dom Quixote, 1993a. . O inumano: considerações sobre o tempo. Lisboa: Editorial

Estampa, 1990. 
The Differend: Phrases in dispute. Minnesota: University of

Minnesota, 1988.

. Moralidades pós modernas. Campinas: Papirus, 1996.

. O saber já não é um meio de emancipação. In: KECHIKIAN, A.

Os filósofos e a educação. Lisboa: Edições Colibri, 1993b, p. 47-53.

NIELSEN NETO, Henrique. Instalação do $1^{\circ}$ Encontro Estadual de Professores de Filosofia.

In: NIELSEN NETO, Henrique (org.). O Ensino da Filosofia no $2^{\circ}$ grau. São Paulo, Sofia Editora, 1986.

NIETZSCHE Friedrich. A Gaia Ciência. São Paulo. Companhia das letras, 2008.

O nascimento da tragédia. São Paulo. Companhia das letras, 2007.

PEGORARO, Olinto. Filosofia: A ressurreição depois do banimento. In: Política da Filosofia no $2^{\circ}$ grau. São Paulo, Sofia Editora, 1986.

QUINTALE NETO, Flavio. Para uma interpretação do conceito de Bildungsroman. In:

Pandaemonium germanicum. São Paulo, n.9, 2005, 155-181 .

SCHILLER Friedrich. A educação estética do homem. São Paulo. Iluminuras, 2010.

SIM, Stuart (org). The Lyotard dictionary. Edinburgh University Press, 2011.

SUAREZ, Rosana. Nota sobre o conceito de Bildung (formação cultural). Kriterion, Belo

Horizonte, n.112, dezembro/2005, p. 191-198.

WEBER, José Fernandez. Bildung e educação. Educação e Realidade, Porto Alegre, vol. 31(2), jun/dez 2006, p. 117-134.

WITTGENSTEIN, Ludwig. Investigações filosóficas. São Paulo: Editora Nova Cultural, 1999. 